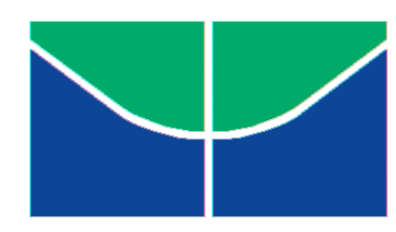

UNIVERSIDADE DE BRASÍLIA INSTITUTO DE QUÍMICA

PROGRAMA DE PÓS-GRADUAÇÃO EM TECNOLOGIAS QUÍMICA E BIOLÓGICA

Hugo de Farias RaMalho

\title{
MODIFICAÇÃO DE BIODIESEL DE SOJA PARA PRODUÇÃO DE ADITIVO COM ATIVIDADE BIOLÓGICA
}

TESE DE DOUTORADO

Brasília - DF

$2^{\circ} / 2015$ 


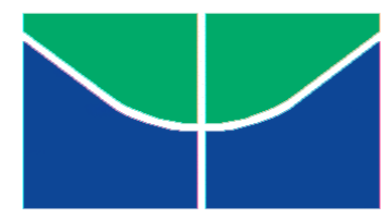

\section{UNIVERSIDADE DE BRASÍLIA INSTITUTO DE QUÍMICA PROGRAMA DE PÓS-GRADUAÇÃO EM TECNOLOGIAS QUÍMICA E BIOLÓGICA}

Hugo de Farias Ramalho

\section{MODIFICAÇÃO DE BIODIESEL DE SOJA PARA PRODUÇÃO DE ADITIVOS COM ATIVIDADE BIOLÓGICA}

Tese apresentada ao Instituto de Química da Universidade de Brasília como requisito parcial para a obtenção do título de Doutor.

Orientador: Paulo Anselmo Ziani Suarez Coorientador: Marcos Juliano Prauchner 


\section{Folha de Aprovação}

Comunicamos a aprovação da Defesa de Tese de Doutorado do (a) aluno (a) Hugo de Farias Ramalho, matrícula $n \cong$ 12/0078589, intitulada "Modificação de Biodiesel de Soja para Produção de Aditivo com Atividade Biológica", apresentada no (a) Auditório do CDT da Universidade de Brasília (UnB) em 15 de dezembro de 2015.

Prof. Dr. Paulo Anselmo Ziani Suarez

Presidente de Banca (IQ/UnB)

Prof. Dr. Angelo Henrique de Lira Machado Membro Titular (IQ/UnB)

Prof. Dr. Wender Alves da Silva

Membro Titular (IQ/UnB)

Prof. Dr. Eduardo Ulisses Xavier Péres Membro Titular (IFB)

Prof. Dr. Mário Roberto Meneghetti Membro Titular (UFAL)

Profa Dra Sarah Silva Brum Membro Suplente (IQ/UnB)

Em 15 de dezembro de 2015.

\ Caixa Postal 4478 - CEP: 70904-970 - Brasilia - DF - BRASIL 


\section{AGRADECIMENTOS}

Agradeço a todos que contribuíram de alguma forma para o trabalho desenvolvido durante meu doutorado. Certamente ele não poderia ter sido desenvolvido e concluído sem a colaboração e o apoio de muitas pessoas.

Não poderia deixar de agradecer primeiramente a meus pais e irmãos pelo apoio incondicional durante toda a minha vida, me ajudando a superar diversas dificuldades profissionais e pessoais.

Agradeço também à minha amada Mayume Kawamura, que me deu força quando eu mais precisei, me incentivou durante todo o tempo e acompanhou de perto tudo o que eu fiz. O meu desenvolvimento profissional e pessoal se deve a toda sua dedicação, paciência e amor, que estará marcado para sempre na minha vida. Aproveito para agradecer à sua família por todo apoio, valorização e reconhecimento.

Ao professor Paulo Suarez pela orientação durante mais de dez anos, pela estrutura e apoio que me deu para trabalhar, e pela amizade.

Ao professor Marcos Juliano Prauchner por toda dedicação como orientador, atenção e discussões longas e produtivas. Uma grande melhora na qualidade deste trabalho só foi possível graças à sua dedicação e paciência.

Ao grande amigo Osvaldo Kojiro Iha, que esteve ao meu lado sempre disposto a ajudar e compartilhar ideias e conhecimentos.

Aos amigos Anderson, Betânia, Fernando, Marcelo, Renato, David, entre outros que sempre me valorizaram e me apoiaram durante esta etapa da minha carreira.

Agradeço à Ellen Rangel e Tamyris Borges pela colaboração com o meu trabalho e discussões produtivas.

Aos professores que aceitaram participar da banca, Prof. Mário Meneghetti, Prof. Eduardo Ulisses, Prof. Wender Alves, Profa. Sarah Brum e o Prof. Ângelo Machado, que contribuíram bastante para a melhora deste trabalho.

Agradeço por fim aos colegas da central analítica e ao Instituto de Química por tornarem possível a realização do meu trabalho. 
Neste trabalho foi empregado um sistema bifásico utilizando o líquido iônico 1butil-3-metilimidazólio para as reações de hidroformilação-condensação com $n$ butilamina utilizando o complexo $\mathrm{HRhCO}\left(\mathrm{PPh}_{3}\right)_{3}$ como precursor catalítico para modificação de biodiesel de soja. Utilizando um excesso do ligante $\mathrm{PPh}_{3}$, a presença do líquido iônico aumentou a seletividade para a formação de imina quando comparada com a reação realizada em condições similares, mas em meio homogêneo. O rendimento para imina alcançou 75\% após 24 h. Por outro lado, na ausência de um excesso de $\mathrm{PPh}_{3}$, o uso do líquido iônico teve efeito contrário para a reação, de forma que a seletividade para imina diminuiu. Este resultado foi atribuído à formação de carbenos N-heterocíclicos que se coordenam com o Rh para formar espécies catalíticas ativas para reações paralelas e/ou consecutivas. Quando um excesso de $\mathrm{PPh}_{3}$ é usado, ele impede a coordenação dos carbenos, mantendo o Rh na forma de complexo ativo para a hidroformilação. Os produtos nitrogenados obtidos apresentaram excelente atividade antimicrobiana contra fungos e bactérias comumente presentes em tanques de armazenamento de combustível. 


\begin{abstract}
A biphasic catalytic system using the ionic liquid 1-butyl-3-methylimidazolium hexafluorophosphate was employed for tandem hydroformylation-amine condensation reactions of soybean biodiesel using $\mathrm{HRhCO}\left(\mathrm{PPh}_{3}\right)_{3}$ as the catalyst precursor and $n$ butylamine. When a tenfold excess of the ligand $\mathrm{PPh}_{3}$ was employed, the presence of the ionic liquid increased the selectivity for imine if compared to the reaction carried out under similar conditions, but in homogeneous media. The yield for imine reached $75 \%$ after $24 \mathrm{~h}$. On the other hand, in the absence of a $\mathrm{PPh}_{3}$ excess, the effect of using the ionic liquid was opposite and the selectivity for imine decreased. This supposedly occurred due to the generation of N-heterocyclic carbenes, which would coordinate to $\mathrm{Rh}$ to form species active for parallel and/or consecutive reactions. When an excess $\mathrm{PPh}_{3}$ is used, it suppresses the carbenes coordination, maintaining the $\mathrm{Rh}$ complex in a form active for hydroformylation. The obtained imine products presented remarkable antimicrobial activity towards a set of fungi and bacteria commonly present in fuel storage tanks.
\end{abstract}




\section{Produção téCNICA E CIENTífiCA ORIUNDA do dOUTORAdo}

1. Ramalho, H. F.; Di Ferreira, K.M.C.; Machado, P.M.A.; Oliveira, R.S.; Silva, L.P.; Prauchner, M.J.; Suarez, P.A.Z.; Biphasic hydroformylation of soybean biodiesel using a rhodium complex dissolved in ionic liquid. Industrial Crops and Products, v.52, p.211 $-218,2014$.

2. Ramalho, H. F., Suarez, P.A.Z.; A Química dos Óleos e Gorduras e seus Processos de Extração e Refino. Revista Virtual de Química, v.5, p.02 - 15, 2013.

3. Suarez, P.A. Z.; Ramalho, H. F., On the Use of Ionic Liquids in Biomass Transformations: Reaction Media and Catalysts. Current Organic Chemistry, v.17, p.229-237, 2013.

4. Suarez, P. A. Z.; Prauchner, M. J.; Rangel, E. T.; Ramalho, H. F.; Silva, T. B.; Processo de modificação química do biodiesel ou outros derivados de ácidos graxos insaturados através da reação de hidroformilação seguida de condensação com aminas, biodiesel modificado, sua ação biocida e outras aplicações. 2014, Brasil. Patente: Privilégio de Inovação. Número do registro: BR10201401389, data de depósito: 09/06/2014, título: "Processo de modificação química do biodiesel ou outros derivados de ácidos graxos insaturados através da reação de hidroformilação seguida de condensação com aminas, biodiesel modificado, sua ação biocida e outras aplicações ", Instituição de registro: INPI - Instituto Nacional da Propriedade Industrial.

5. Ramalho, H. F.; Ferreira, K. M. C.; Machado, P. M. A.; Silva, T. B.; Rangel, E. T.; Prauchner, M. J. ; Suarez, P. A. Z.; Production of Additives with Antimicrobial Activity via Tandem Hydroformylation-amine Condensation of Soybean FAME Using an Ionic Liquid-Based Biphasic Catalytic System. Journal of the Brazilian Chemical Society, 2015 (aceito para publicação). 


\section{SUMÁRIO}

1. Introdução

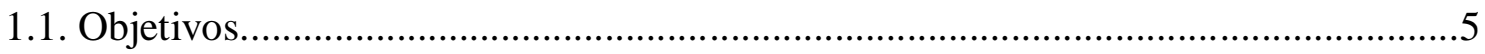

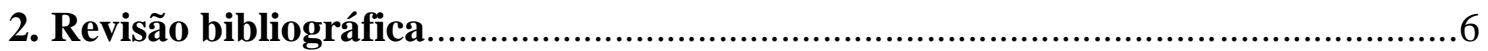

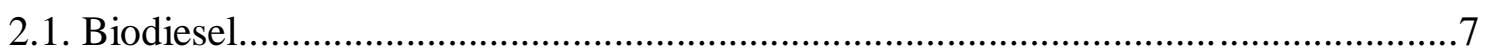

2.1.1. Utilização de óleos e gorduras como combustíveis...................................................

2.1.2. Reação de transesterificação para produção de biodiesel............................................

2.1.3. Especificações técnicas do biodiesel......................................................................9

2.1.4. Contaminação microbiana de combustíveis...........................................................10

2.2. Líquidos Iônicos..............................................................................................13

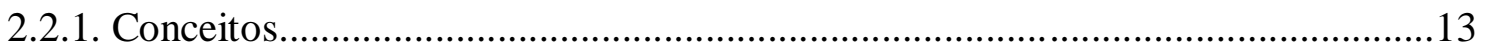

2.2.2. LI’s derivados do cátion 1,3-dialquilimidazólio...................................................14

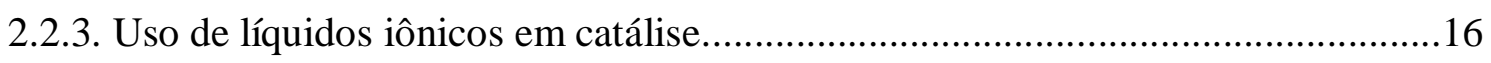

2.2.4. Caráter "não inocente" dos líquidos Iônicos.........................................................17

2.3. Hidroformilação/hidroaminometilação..................................................................18

2.4. Modificações químicas das moléculas de biodiesel..................................................22

3. Metodologia

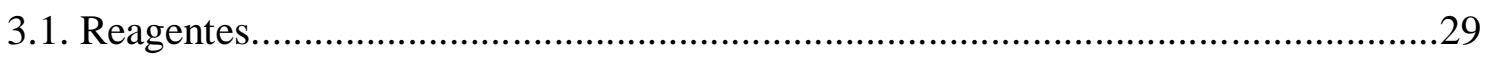

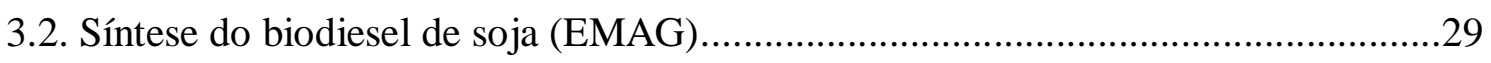

3.3. Síntese do líquido iônico hexafluorofosfato de 1-n-butil-3-metil-imidazólio...........30

3.4. Reações de hidroformilação em presença de $n$-butilamina........................................32

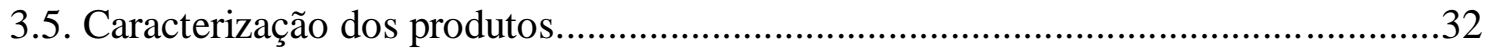

3.6.Cálculos de conversão, seletividade e rendimento ……………………………….....33

3.6.1 Determinação da formação de aldeídos...............................................................33

3.6.2. Reações de hidroiminometilação utilizando $n$-butilamina.........................................

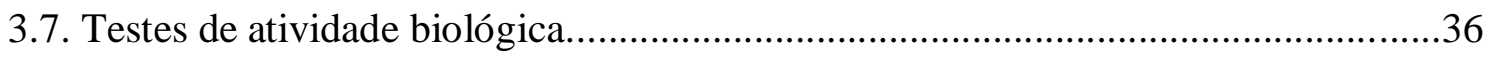

3.7.1. Teste de difusão em ágar...............................................................................36

3.7.2 Testes microbiológicos de suscetibilidade..............................................................

3.7.3. Teste de inibição de crescimento dos microrganismos com pesagem da biomassa

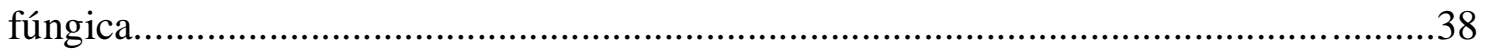


4.1. Conversão do óleo de soja em EMAG.....................................................................40

4.2. Reações de hidroformilação em presença e ausência de $n$-butilamina.....................41

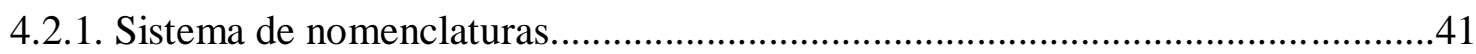

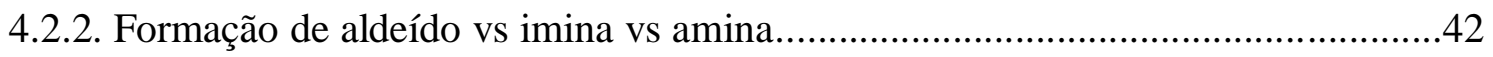

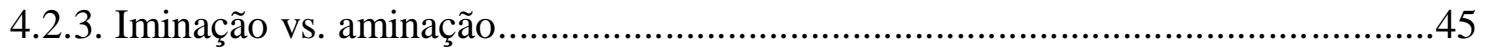

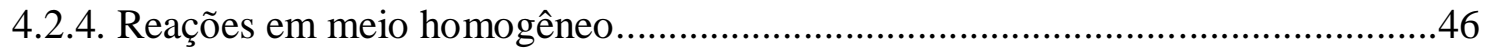

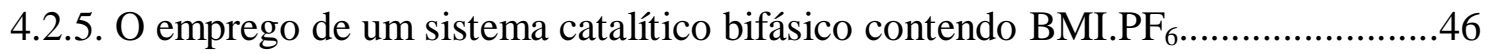

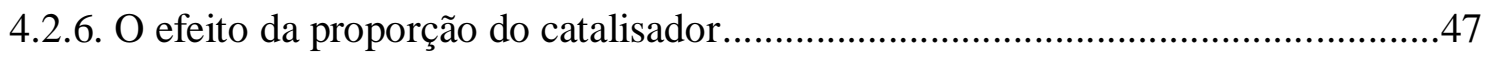

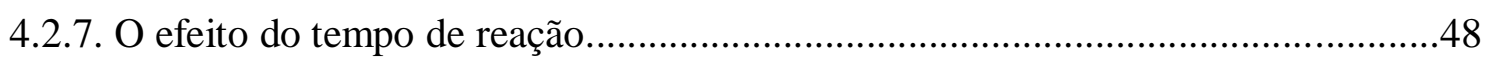

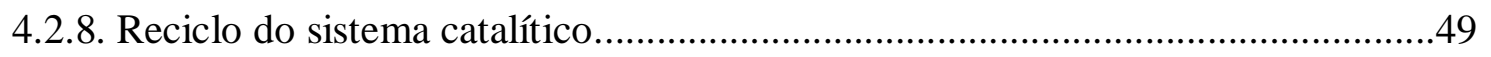

4.2.9. Tentativa de hidrogenação da imina utilizando condições redutivas mais severas...

4.2.10. Redução dos produtos de hidroiminometilação com Pd/C..................................51

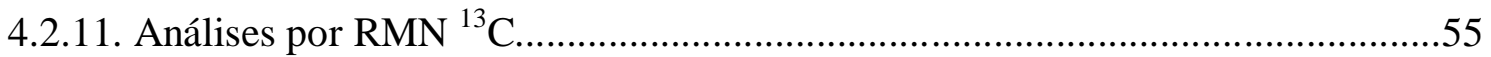

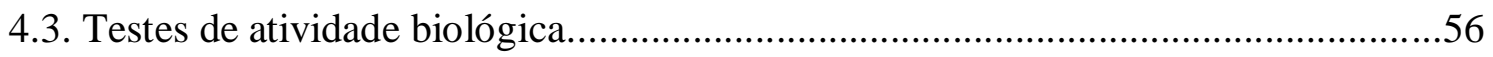

4.3.1. Teste de difusão em ágar para o EMAGHIM....................................................56

4.3.2. Teste da suscetibilidade utilizando o EMAGHIM...............................................57

4.3.3. Resultados para o teste de inibição de crescimento dos microrganismos com

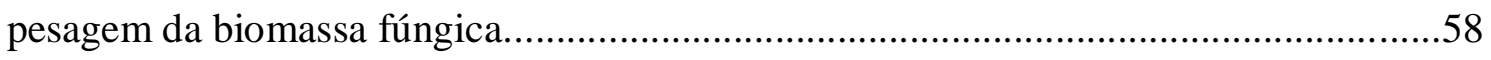

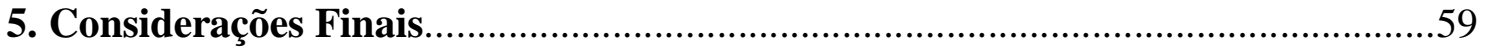

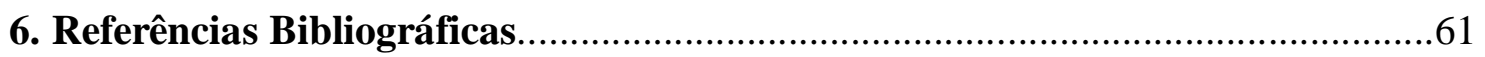




\section{LISTA DE ABREVIATURAS E ACRÔNIMOS}

BMI.PF $_{6}$

CLAE

DAG

EAG

EMAG

EEAG

EMAGE

EMAGH

EMAGHIM

EMAGHAM

MAG

$\mathrm{RMN}^{1} \mathrm{H}$

$\mathrm{RMN}^{13} \mathrm{C}$

TAG
Hexafluorofosfatode1-butil-3-metil-imidazólio

Cromatografia Líquida de Alta Eficiência

Diacilglicerídeo

Éster de ácido graxo

Éster metílico de ácido graxo

Éster Etílico de Ácido Graxo

Éster metílico de ácido graxo epoxidado

Éster metílico de ácido graxo hidroformilado

Éster metílico de ácido graxo hidroiminometilado

Éster metílico de ácido graxo hidroaminometilado

Monoacilglicerídeo

Ressonância magnética nuclear de ${ }^{1} \mathrm{H}$

Ressonância magnética nuclear de ${ }^{13} \mathrm{C}$

Triacilglicerídeo 


\section{LISTA DE TABELAS}

Tabela 1. Composição do biodiesel obtido por meio da transesterificação de óleo de soja. .40

Tabela 2. Conversão, seletividade e rendimento para as reações de hidroformilação realizadas em presença de $n$-butilamina. .41

Tabela 3. Resultados do teste de difusão em ágar, para fungos, das blendas EMAGHIM/EMAG .56

Tabela 4. Resultados do teste de difusão em ágar para bactérias das blendas EMAGHIM/EMAG .57

Tabela 5.CIM das blendas de EMAGIM/EMAG no teste de suscetibilidade fúngica...57

Tabela 6. CIM das blendas de EMAGHIM/EMAG no teste de suscetibilidade bacteriana. .58 


\section{LISTA DE FIGURAS}

Figura 1. (a) ácido oleico; (b) ácido linoleico; (c) ácido linolênico................................3

Figura 2. Reação de Hidroformilação de Olefinas..........................................................

Figura 3. Etapas de condensação e redução na reação de hidroaminometilação.............4

Figura 4. Estrutura química dos triacilglicerídeos.........................................................

Figura 5. Transesterificação de triacilglicerídeos........................................................

Figura 6. Aditivos antioxidantes utilizados no biodiesel: BHT (Butilhidroxitolueno), TBHQ (Tetrabutilhidroquinona), BHA (butilhidroxianisol), PG (propilgalato), PA

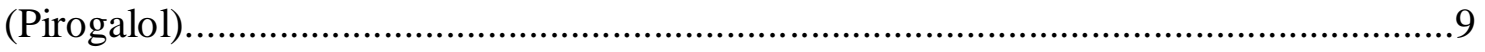

Figura 7. Exemplos de líquidos iônicos derivados do cátion 1,3-dialquilimidazólio $\left(\mathrm{R}_{1}\right.$,

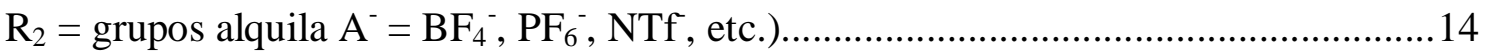

Figura 8. (a) Representação do arranjo 2D de líquidos iônicos imidazólicos; (b) visão esquemática do arranjo 3D dos cátions dialquilimidazólicos mostrando os canais nos

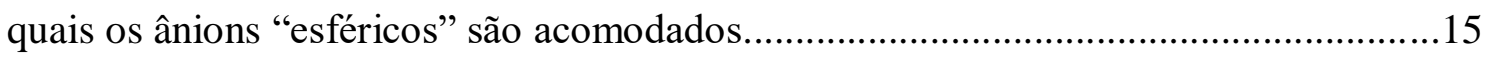

Figura 9. Reatividade dos cátions imidazólicos para formação de carbenos NHC........17

Figura 10. Hidroformilação de derivado de estireno com complexo de Rh/carbeno $N$ -

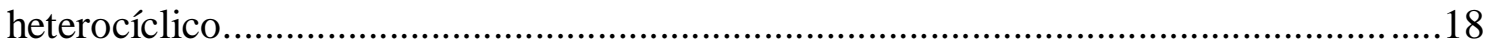

Figura 11. Ciclo catalítico para a hidroformilação (adaptada da referência 51)............19

Figura 12. Mecanismo para hidrogenação seletiva de biodiesel (referência 10)............23

Figura 13. Reação de epoxidação de oleato de metila (referência 12)...........................24

Figura 14 (a) Mecanismo de reação da aminólise; (b) Mecanismo de ativação do grupo

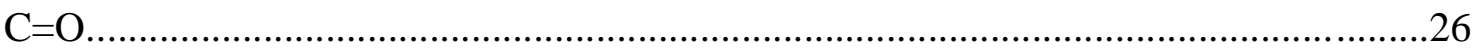

Figura 15. Ligação entre duas moléculas de oleato de etila através de uma amina atuando como ponte .27

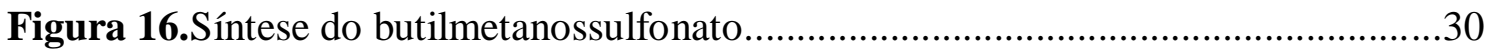

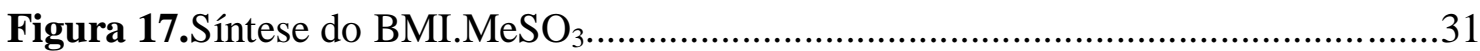

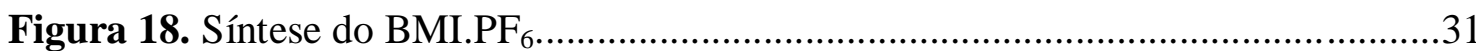

Figura 19. Principais atribuições nos espectros de RMN ${ }^{1} \mathrm{H}$ para o EMAG (a) e seu

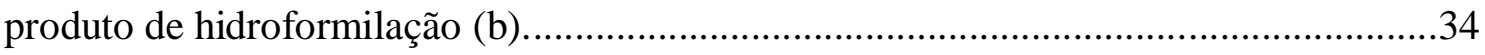

Figura 20. Principais atribuições nos espectros de $\mathrm{RMN}{ }^{1} \mathrm{H}$ para a reação de hidroformilação de EMAG na presença de $n$-butilamina..................................................36

Figura 21. Prováveis produtos formados a partir da hidroiminometilação de EMAG...... 
Figura 22. Espectros de infravermelho do (a) EMAG de soja e dos produtos de sua reação de hidroformilação em (b) ausência (EMAGHF) e (c) na presença de $n$ butilamina (EMAGHIM).

Figura 23. Espectro de RMN ${ }^{1} \mathrm{H}$ do EMAGHIM mostrando sobreposição dos picos do radical $n$-butila com picos de $\mathrm{CH}_{2}$ e $\mathrm{CH}_{3}$ da região graxa das cadeias. .44

Figura 24. Microscopia de força atômica do produto LI.0.24.750 indicando a formação de nanopartículas de ródio no meio reacional. 48

Figura 25. Ligante trifenilfosfina trissulfonada .50

Figura 26. Espectros de infravermelho do EMAGHIM e do produto obtido após tentativa de hidrogenação. .51

Figura 27. Espectros do EMAGHIM, da sua hidrogenação no mesmo sistema e de sua hidrogenação com $\operatorname{Pd}(\mathrm{C})$ .52

Figura 28. $\mathrm{RMN}{ }^{1} \mathrm{H}$ de $600 \mathrm{MHz}$ da mistura de partida empregada na reação com $\mathrm{Pd} / \mathrm{C}$ (LI.0.24.750) .53

Figura 29. $\mathrm{RMN}{ }^{1} \mathrm{H}$ de $600 \mathrm{MHz}$ do produto de hidrogenação de LI.0.24.750 com Pd/C .53

Figura 30. Espectros de RMN ${ }^{13} \mathrm{C}$ (APT) das amostras de EMAGIM e EMAGHAM..55

Figura 31. Valores de peso seco da biomassa fúngica para as amostras de EMAG puro e EMAG/EMAGHIM 5 \% (v/v) .58 
Capítulo 1

INTRODUÇÃO 


\section{Introdução}

A produção e uso de ésteres metílicos e etílicos de ácidos graxos (EMAG e EEAG, respectivamente) obtidos a partir de óleos ou gorduras de origem vegetal ou animal, mais conhecidos como biodiesel, tem aumentado abruptamente ao longo dos últimos anos devido a preocupações relacionadas principalmente ao aquecimento global e à disponibilidade de petróleo. ${ }^{1}$ No Brasil, a produção de biodiesel alcançou 3milhões de metros cúbicos em $2014 .^{2}$

Apesar de haver no país programas de utilização de combustíveis derivados de biomassa desde a década de 1980, apenas recentemente estes combustíveis ganharam destaque no Brasil. Assim, o programa nacional de produção e uso de biodiesel, que teve início em 2003, determinou a obrigatoriedade do uso de $2 \%$ de biodiesel (B2) no diesel a partir de 2008, e $5 \%$ de biodiesel (B5) a partir de 2013. Este cronograma foi posteriormente alterado com antecipação das datas de obrigatoriedade destas adições. Atualmente a adição de 7\% de biodiesel ao diesel comercial (B7) é obrigatória, sendo que o uso de porcentagens ainda maiores está atualmente em discussão. A substituição de derivados de petróleo por biodiesel é favorável do ponto de vista ambiental porque este biocombustível tem origem de fontes renováveis, o que contribui para um menor acúmulo de $\mathrm{CO}_{2}$ na atmosfera. Outra vantagem importante é que o emprego de biodiesel dimini a emissão de material particulado para atmosfera, além de não liberar compostos aromáticos ou sulfurados. 3,4

O biodiesel é normalmente produzido por meio das reações de esterificação de ácidos graxos ou transtesterificação de triacilglicerídeos (componentes principais dos óleos e gorduras). ${ }^{5}$ No Brasil, o biodiesel de óleo de soja é o mais produzido. Ele é constituído principalmente por ésteres de ácidos graxos insaturados, como o oleico (24\%), o linoleico (54\%) e o linolênico (6\%) (Figura 1, adaptada da referência 6). A presença de ligações duplas tem como vantagem principal a diminuição do ponto de congelamento do biodiesel de soja. ${ }^{6}$ Por outro lado, elas diminuem a estabilidade oxidativa do combustível. ${ }^{7}$

Outro problema técnico associado ao uso do biodiesel diz respeito à potencialização da contaminação microbiana em tanques de armazenamento de combustíveis, o que ocorre principalmente devido ao caráter levemente higroscópico do biodiesel causado pela presença do grupo éster., ${ }^{8,9}$ 

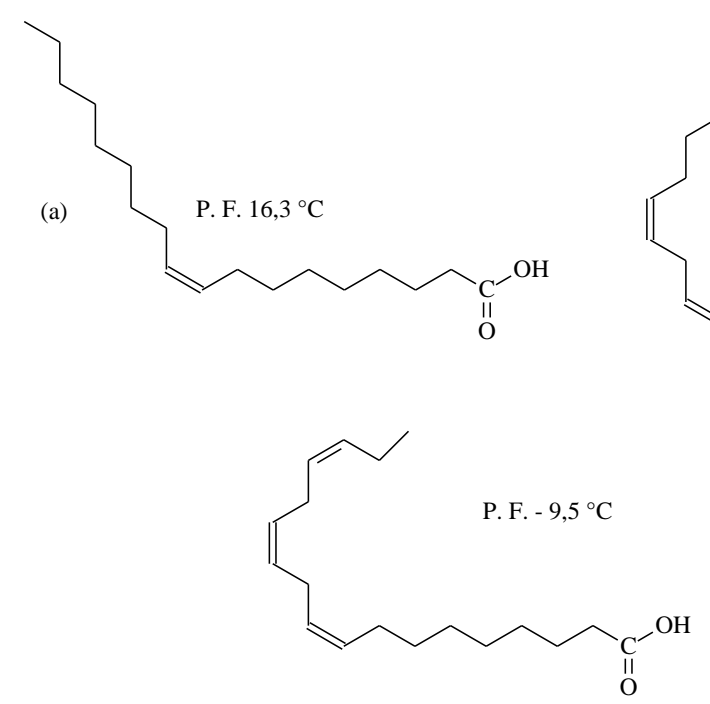

P. F. $-5^{\circ} \mathrm{C}$

(b)

(c)

Figura 1: (a) ácido oleico; (b) ácido linoleico; (c) ácido linolênico.

Atualmente, a maneira mais eficaz para contornar os problemas da baixa estabilidade oxidativa e da susceptibilidade à contaminação microbiana é por meio da adição de aditivos antioxidantes e biocidas, respectivamente. Entretanto, uma vez que os problemas citados se originam da composição das moléculas do biodiesel, a saber, a presença de insaturações e do grupo éster, uma maneira mais elegante e ambientalmente correta de se ajustar as propriedades do combustível sem a necessidade do emprego de aditivos é por meio da modificação destas funções. ${ }^{10-12}$

Uma forma de contornar a baixa estabilidade do biodiesel de soja sem prejudicar suas propriedades a frio é por meio da reação de hidroformilação, que consiste na adição de um grupo formila $(\mathrm{H}-\mathrm{C}=\mathrm{O})$ e de um átomo de hidrogênio na forma cis (Figura 2). ${ }^{13}$ Os aldeídos resultantes são compostos muito reativos e versáteis que podem ser usados como materiais de partida para produção de diversos compostos como álcoois, ácidos carboxílicos, aminas e éteres. ${ }^{14}$
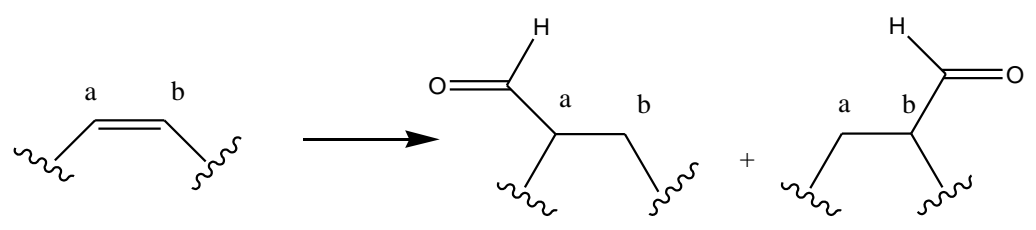

Figura 2. Reação de Hidroformilação de Olefinas

Em um trabalho anterior, um sistema catalítico bifásico usando líquido iônico foi empregado pela primeira vez para a hidroformilação de EMAG de soja. ${ }^{15}$ O líquido 
iônico (LI) e o precursor catalítico empregados foram o hexafluorofosfato de 1-butil-3metilimidazólio $\left(\mathrm{BMI} \cdot \mathrm{PF}_{6}\right)$ e o $\mathrm{HRhCO}\left(\mathrm{PPh}_{3}\right)_{3}$, respectivamente. Os resultados obtidos sugeriram que o LI estabilizou o complexo de Rh na forma ativa para a hidroformilação e evitou que reações laterais e/ou consecutivas ocorressem, levando a altos rendimentos para a formação de aldeídos. Além disso, a adição de um excesso de $\mathrm{PPh}_{3}$ aumentou tanto a conversão quando a seletividade para aldeídos. Assim, concluiu-se que a(s) forma(s) ativa(s) para a hidroformilação consista(m) em complexo(s) contendo o ródio coordenado à $\mathrm{PPh}_{3}$, sendo sua formação favorecida pela presença de um excesso do ligante devido ao deslocamento do equilíbrio.

Se a hidroformilação é realizada na presença de aminas primárias, secundárias ou do íon amônio, tem-se a formação de produtos de condensação. ${ }^{16}$ A adição nucleofílica do amônio ou amina ao aldeído formado gera um O,N-semiacetal que sofre subsequente desidratação para formar imina (se o íon amônio ou amina primária são usados) ou enamina (se for usada uma amina secundária). Como a hidroformilação é realizada na presença de $\mathrm{H}_{2}$ e o catalisador empregado normalmente é ativo para hidrogenação, a imina ou enamina formada geralmente é reduzida a amina primária, secundária ou terciária. As etapas de condensação e redução estão representadas na Figura 3. A reação global de conversão de um grupo olefina em amina recebe o nome de hidroaminometilação.
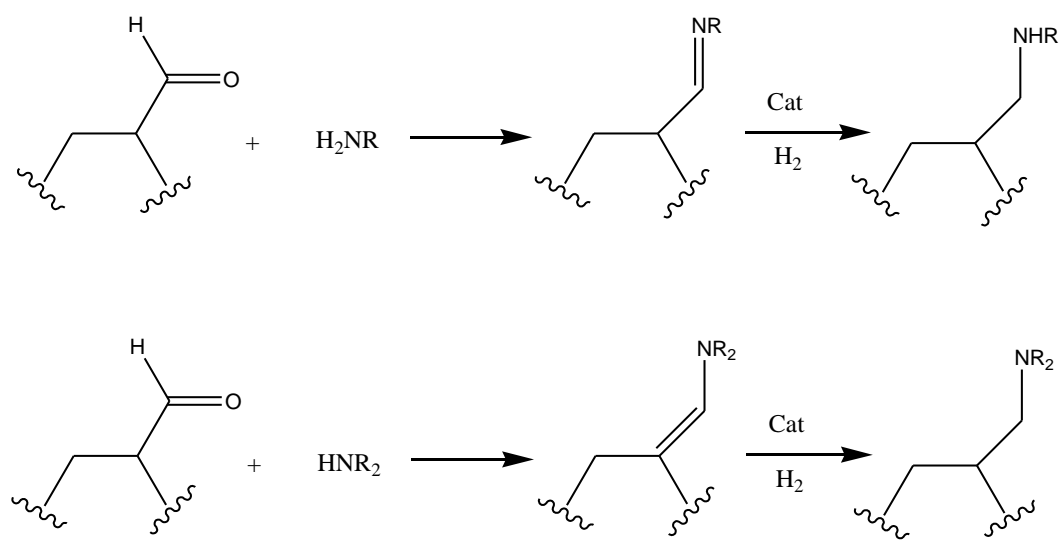

Figura 3. Etapas de condensação e redução na reação de hidroaminometilação.

Neste ponto, é válido destacar a existência de vários estudos na literatura que relatam moléculas nitrogenadas com considerável atividade biológica, sendo que a maioria delas é derivada de compostos naturais. Por exemplo, Graebin et al. mostraram 
que alguns produtos derivados da hidroaminometilação do (+)-limoneno apresentaram atividade in vitro contra a Leishmania (V.) braziliensis. ${ }^{17}$ Além disso, eles identificaram dois novos derivados do limoneno com promissora atividade contra Trypanosoma cruzi. Por sua vez, Ferrel e Merkler publicaram uma revisão sobre a atividade biológica de amidas de ácidos graxos que foram isoladas de alguns mamíferos. ${ }^{18}$

Levando em conta o contexto apresentado, neste trabalho buscou-se sintetizar moléculas nitrogenadas derivadas do biodiesel de soja que apresentassem atividade antimicrobiana. Para isto, procedeu-se a reação de hidroformilação de EMAG de soja na presença de $n$-butilamina (hidroaminometilação), que foi escolhida por apresentar uma

excelente reatividade quando comparada com outras aminas reportadas na literatura. ${ }^{76}$ Assim, os produtos da hidroaminometilação foram usados como modelo para estudo da atividade antimicrobiana, que foi avaliada através de testes padrão para atividade biocida.

\subsection{Objetivos}

\subsubsection{Objetivo Geral}

Este trabalho tem como objetivo geral realizar a modificação de biodiesel metílico de soja por meio da reação de hidroformilação na presença de $n$-butilamina (hidroaminometilação) para obtenção de aditivos nitrogenados com potencial atividade biológica.

\subsubsection{Objetivos específicos}

- Estudo da reação de hidroformilação de EMAG na presença de $n$-butilamina em um sistema catalítico bifásico, à base do líquido iônico $\mathrm{BMI} \cdot \mathrm{PF}_{6}$, para obtenção de derivados nitrogenados;

-Estudo da capacidade de reaproveitamento dos sistemas bifásicos para seguidas reações;

- Estudo da atividade antimicrobiana dos produtos nitrogenados visando a sua utilização como aditivos antimicrobianos. 
CAPítulo 2

REVISÃO BIBLIOGRÁFICA 


\section{Revisão Bibliográfica}

\subsection{Biodiesel}

\subsubsection{Utilização de óleos e gorduras como combustíveis}

Óleos e gorduras são constituídos principalmente por triacilglicerídeos, substâncias que podem ser entendidas como o resultado da reação de esterificação de três moléculas de ácidos graxos com uma molécula de glicerol (Figura 4). O uso desses materiais como combustível teve início com a invenção do motor de combustão interna, desenvolvido por Rudolph Diesel no final do século XIX, que utilizou óleo de amendoim em seus testes. Porém, devido à alta disponibilidade de petróleo no período, esse combustível fóssil acabou sendo escolhido em detrimento aos óleos e gorduras. Além disso, a busca por uma maior eficiência fez com que os motores assumissem ao longo dos anos características que impedem o uso de óleos ou gorduras diretamente como combustíveis. $^{19}$

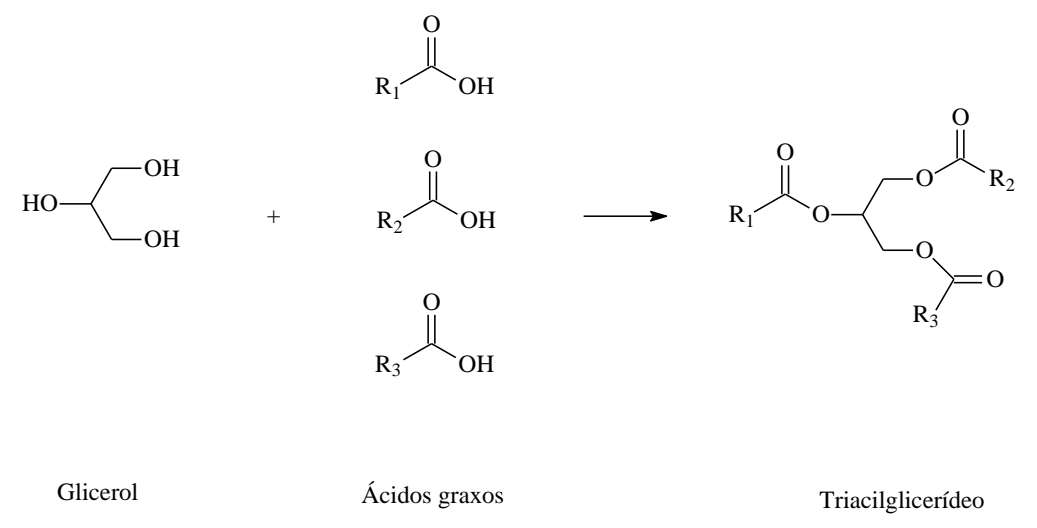

Figura 4. Estrutura química dos triacilglicerídeos.

No Brasil, o uso de biocombustíveis iniciou-se discretamente na década de 1940. Nas décadas de 1970 e 1980, foram criados os programas Pró-álcool e o Pró-óleo que incentivavam, respectivamente, o uso de bioetanol e de óleos ou gorduras como combustíveis. Esses programas se apresentaram como tentativas de superar a crise de abastecimento de petróleo existente na época. No caso do Pró-óleo, a sua proposta era que uma pequena porcentagem de óleo ou derivado deste fosse misturada ao diesel convencional. Em 2003, foi criado no Brasil o Programa Nacional de Produção e Uso do Biodiesel (PNPB), responsável por desenvolver políticas que introduzam o biodiesel, 
produto resultante da alcoólise de óleos vegetais ou gorduras animais ou da esterificação de ácidos graxos, na matriz energética brasileira. Este programa determinou, por meio de leis e normas, que quantidades cada vez maiores de biodiesel fossem adicionadas ao diesel comum com o passar dos anos. ${ }^{20}$

\subsubsection{Reação de transesterificação para produção de biodiesel}

De acordo com resolução da ANP (resolução 14, de 11 de maio de 2012), o biodiesel é definido como "combustível composto de alquil ésteres de ácidos carboxílicos de cadeia longa, produzido a partir da transesterificação e/ou esterificação de matérias graxas, de gorduras de origem vegetal ou animal”. A reação de transesterificação ocorre normalmente na presença de um catalisador e de um excesso de álcool de cadeia curta, como metanol ou etanol, formando ésteres de ácido graxo (EAG, Figura 5).

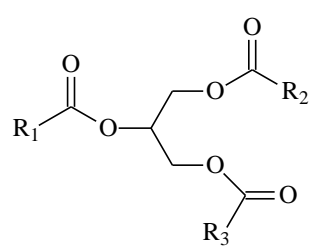

Triacilglicerídeo
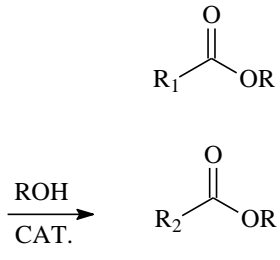

$\overbrace{\mathrm{OR}}^{\mathrm{O}}+\mathrm{HOH}$

$\mathrm{R}_{3} \stackrel{\mathrm{O}}{\stackrel{\mathrm{OR}}{\mathrm{O}}}$

EAG
Glicerina

Figura 5. Transesterificação de triacilglicerídeos.

Os catalisadores mais comumente usados nas reações de transesterificação são bases fortes $(\mathrm{KOH}, \mathrm{NaOH})$ e ácidos fortes $\left(\mathrm{H}_{2} \mathrm{SO}_{4}, \mathrm{HCl}\right)$. Diversos catalisadores alternativos também apresentam atividade para este tipo de reação. Entre eles, é possível citar as enzimas, as bases orgânicas como guanidinas e amidinas, complexos homogêneos e catalisadores heterogêneos como aluminossilicatos e óxidos metálicos com caráter ácido de Lewis. Todos estes catalisadores apresentaram altas taxas de conversão de triacilglicerídeos em ésteres metílicos de ácidos graxos. ${ }^{6}$ 


\subsubsection{Especificações técnicas do biodiesel}

O biodiesel deve seguir rigorosas normas e padrões para que possa ser comercializado. No caso do biodiesel de soja, que corresponde, em média, a $75 \%$ da produção nacional, ${ }^{1}$ a estabilidade oxidativa está abaixo dos padrões estabelecidos pelas especificações da ANP (EN14112). Esta baixa estabilidade oxidativa está associada principalmente ao alto grau de insaturação dos ácidos graxos componentes do biodiesel de soja, o que o torna altamente susceptível à oxidação. Quando o combustível formado por derivados destes ácidos graxos entra em contato com o oxigênio atmosférico, pode ocorrer a formação de peróxidos, hidroperóxidos, ácidos graxos leves e outros compostos oxigenados $^{21}$. Por este motivo, faz-se necessária a adição de antioxidantes (Figura 6) para que as especificações da ANP sejam obedecidas.

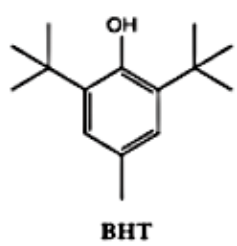<smiles>Oc1cccc(O)c1O</smiles>

PA<smiles>CC(C)(C)c1cc(O)ccc1O</smiles><smiles>CCCOC(=O)c1cc(O)c(O)c(O)c1</smiles>

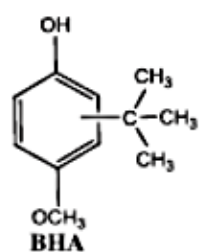

BHA

Figura 6. Aditivos antioxidantes utilizados no biodiesel: BHT (Butilhidroxitolueno), TBHQ (Tetrabutilhidroquinona), BHA (butilhidroxianisol), PG (propilgalato), PA

(Pirogalol).

Costuma-se também combinar outra matéria-prima com baixo teor de insaturação, como o sebo bovino ou óleo de coco, com o biodiesel de soja para aumentar a estabilidade do combustível. Porém, esta alternativa apresenta o inconveniente de aumentar a temperatura de cristalização do biodiesel devido ao aumento do teor de cadeias saturadas, prejudicando suas propriedades a frio. ${ }^{22}$ 


\subsubsection{Contaminação microbiana de combustíveis}

\subsubsection{Biodiesel: biodegradabilidade vs. biodeterioração}

Apesar dos benefícios oriundos do uso do biodiesel como combustível, os EMAGs são mais facilmente metabolizados pela microbiota do que os hidrocarbonetos, fazendo com que o biodiesel seja mais biodegradável do que os combustíveis derivados do petróleo. Pasqualino et al. (2006) comparou a biodegradabilidade do biodiesel com a do diesel de petróleo e da gasolina usando um inóculo contendo lodo ativado fornecido pela indústria municipal de tratamento de água de Tarragona, Espanha. ${ }^{23}$ Eles observaram que a biodegradabilidade do biodiesel foi maior que $98 \%$ após 28 dias, enquanto para o diesel e para a gasolina foi 50 e $60 \%$, respectivamente. Além disso, outros autores demonstraram que o biodiesel pode promover e acelerar a biodegradação dos próprios hidrocarbonetos. Assim, eles concluíram que o uso de misturas de biodiesel com combustíveis derivados de petróleo é vantajoso no ponto de vista de atenuar os impactos negativos causados por derramamento de combustíveis no solo ou em ambientes aquáticos, podendo até atuar na biorremediação de ambientes contaminados por derramamento de combustível. ${ }^{24,25}$

Se por um lado a biodegradabilidade é, da perspectiva ambiental, uma vantagem, ela ocasiona, por outro lado, diversos problemas técnicos relacionados ao armazenamento de combustíveis. Neste caso, a biodegradação pode ser mais bem referida como biodeterioração, porque ela induz a mudanças químicas e físicas que alteram e comprometem a qualidade do combustível. A biodeterioração também leva à formação de biofilmes, que promovem corrosões microbiologicamente induzidas dos tanques, leituras inadequadas dos medidores e formação de biossedimentos, que provocam entupimento dos filtros e bloqueio e desgaste de tubulações (Passman and Dobranick, 2005; Gaylarde et al., 1999). ${ }^{25,26}$

Neste contexto, muitos autores desenvolveram estudos em laboratório e no campo para avaliar a biodeterioração de blendas de biodiesel/diesel. A maioria deles confirmou que a presença de biodiesel acelera a biodeterioração do diesel (Bücker et al., 2011; Schleicher et al., 2009; Zimmer et al., 2013), mas a razão para isto acontecer ainda é desconhecida. ${ }^{27-29}$ As possíveis razões seriam: i) o biodiesel aumentaria a população total de microrganismos; ii) fatores que favorecem o crescimento e/ou 
enzimas necessárias para a degradação do diesel seriam produzidos durante a deterioração do biodiesel; iii) aconteceria um processo cometabólico no qual os microrganismos usam o biodiesel como fonte de carbono/energia para degradar o diesel.

É importante destacar que o aumento da biodegradabilidade de combustíveis de petróleo na presença de biodiesel não é um consenso na literatura. Por exemplo, Mariano et al. (2008) relataram que a biodegradação dos hidrocarbonetos não foi acelerada na presença de biodiesel. ${ }^{30}$ Além disso, Owsianiak et al. (2009) observaram que a biodegradação de algumas misturas específicas de diesel/biodiesel foi mais lenta do que em diesel convencional puro. ${ }^{31}$ Porém, estes resultados parecem ser dependentes de um grande número de variáveis e condições que afetam o crescimento e atividade microbiana, como temperatura, $\mathrm{pH}$, composição do sistema, natureza do microrganismo etc. Por exemplo, Junior et al. assumiram que a biodegradação de diesel de petróleo foi maior do que a biodegradação de biodiesel e blendas de diesel/biodiesel devido à presença do antioxidante terc-butil-hidroquinona (TBHQ) no biodiesel que eles usaram.

Microrganismos como fungos filamentosos, leveduras e bactérias aeróbias e anaeróbias foram identificados como contaminantes de combustíveis (Gaylarde et al., 1999; Passman, 2005). ${ }^{25,26}$ Eles podem contaminar os combustíveis a partir do ar, do solo, de água de lavagem poluída ou até mesmo através de tubulações contaminadas ou tanques que não foram devidamente limpos.

Uma grande diversidade de espécies de bactérias, leveduras e fungos filamentosos já foram isoladas, apresentando a capacidade de crescer em sistemas de estocagem de combustíveis. Entre as bactérias aeróbias, podem citar os gêneros: Acinetobacter, Aerobacter, Alcaligenes, Bacillus, Brevibacterium, Clostridium, Corynebacterium, Enterobacter, Flavobacterium, Pasteurella, Pseudomonas, Rhodococcus e Serratia. Os crescimentos de bactérias anaeróbias do tipo redutoras de sulfato e desnitrificantes também já foram detectados, além de leveduras dos gêneros Candida, Rhodotorula e Saccharomyces, e fungos filamentosos dos gêneros Acremonium, Alternaria, Aspergillus, Cephalosporium, Chaetomium,Cladosporium, Curvularia, Drechslera, Epicoccum, Fusarium, Geomyces, Geotrichum, Gliomastix, Helminthosporium, Homoconis, Humicola, Mucor, Paecilomyces, Penicillium, Pestalotiopsis, Phialophora, Phoma, Phomopsis, Pseudallescheria, Rhinocladiella, Sordaria, Stemphylium, Trichoderma, Trichosporum e Ulocladium. ${ }^{32}$

Dependendo do grau de contaminação, pode-se observar o escurecimento da 
água presente no fundo dos tanques, resultantes da precipitação de sulfeto de ferro, e com cheiro característico de ácido sulfídrico, devido à atividade das bactérias anaeróbias redutoras de sulfato. Outro ponto importante é que a contaminação microbiana no combustível contribui para o aumento da instabilidade dos hidrocarbonetos, acelerando reações que produzem mais sedimentos de origem química. As consequências de um combustível contaminado repercutem no funcionamento dos veículos através da saturação de filtros e desgaste de bicos injetores, comprometendo o rendimento dos motores. ${ }^{33}$

A água é um fator essencial para a atividade microbiana. Assim, os microrganismos proliferam e são metabolicamente ativos em interfaces óleo-água, onde a disponibilidade de água e nutrientes é maior (Passman, 2005). ${ }^{25}$ Apenas alguns microlitros de água são suficientes para permitir que um microrganismo cresça. Logo que o metabolismo molecular começa, ocorre a produção de mais água, fazendo com que este ciclo de produção de água fique cada vez maior (Gaylarde et al., 1999). ${ }^{26}$ Assim, a presença de grupos funcionais oxigenados polares nos EMAGs, que fazem com que o biodiesel seja levemente higroscópico, parece ser um dos principais fatores que aumentam o risco da biodeterioração durante o armazenamento de biodiesel puro ou misturado com o diesel convencional.

Outro fator que pode agravar os problemas relacionados a biodeterioração de combustíveis é a diminuição do conteúdo de enxofre no diesel automotivo. Durante o processo de hidrodessulfurização, os teores de enxofre e compostos aromáticos e fenólicos são drasticamente reduzidos ou até removidos do combustível. Como estes compostos são inibidores de crescimento microbiano, sua eliminação contribui para um aumento da suscetibilidade à contaminação microbiana.

Uma forma de minimizar a biodeterioração é realizar uma drenagem frequente de água dos tanques de armazenamento. Porém, manter um tanque de armazenamento livre da presença de água não é um procedimento trivial. Isto se torna ainda mais desafiador quando se trata de armazenamento de biodiesel devido à sua citada afinidade com a água. Assim, é importante recorrer a substâncias que inibam ou controlem o crescimento microbiano (biocidas).

Na grande maioria dos casos, os problemas relativos à contaminação microbiana somente são investigados quando danos nos tanques e nos equipamentos começam a aparecer. Os custos geralmente são altos para a desativação e recuperação de tanques 
armazenadores danificados. ${ }^{34}$ Com o desenvolvimento de microrganismos, ocorre a formação de biomassa microbiana na interface óleo-água. As consequências mais relevantes da presença desta biomassa são: obstrução de filtros, tubulações e mangueiras; aumento da quantidade de água no sistema; presença de produtos poliméricos extracelulares resultantes de atividade bacteriana, que incorporam à biomassa interfacial do sistema; produção de biossurfactantes, que emulsionam o hidrocarboneto e a água, e a migração da biomassa microbiana para a fase oleosa.

O uso de aditivos para tratamento de combustível representa apenas uma pequena fração do mercado de biocidas. Na verdade, este é um mercado considerado apenas secundário, e reutiliza produtos que foram testados para atuar como aditivos para outras funções. Além disso, existem poucos trabalhos na literatura sobre o uso de biocidas para tratamento de combustíveis. A maioria deles consiste na avaliação do desempenho de produtos comercialmente disponíveis, como misturas de dioxaborinano, isotazolinonas e morfolinas, conforme documentado em uma revisão feita por Passman (2013). ${ }^{35}$

Apesar de ser ativo para uma gama de fungos, leveduras e bactérias aeróbias e anaeróbias, um biocida ideal para combustíveis deve ser capaz de não promover efeitos adversos nas especificações dos combustíveis; não deve ser capaz de corroer tanques, bombas, motores etc.; ter compatibilidade física e química com o combustível; ser capaz de penetrar a massa microbiana; ser seguro para manuseio; ter baixo impacto ambiental (ser biodegradável e livre de enxofre ou metais pesados); e apresentar boa relação custobenefício.

\subsection{Líquidos Iônicos}

\subsubsection{Conceitos}

Os líquidos iônicos são definidos como estruturas supramoleculares compostas somente por íons, com ponto de fusão abaixo de $100{ }^{\circ} \mathrm{C}$. Normalmente, os sais que apresentam estas características contêm cátions orgânicos como o tetralquilamônio, o $n$ alquilpiridínio, o tetralquilsulfônio, o trialquilsulfônio e o 1,3-dialquilimidazólio, sendo os derivados deste último os mais conhecidos. É possível encontrar, na literatura, diversos estudos sobre as aplicações e propriedades desses materiais que evidenciam sua importância. ${ }^{37}$ 


\subsubsection{Líquidos iônicos derivados do cátion 1,3-dialquilimidazólio}

Entre os líquidos iônicos citados anteriormente, os derivados do cátion 1,3dialquilimidazólio (Figura 7) apresentam-se como os mais atraentes, pois possuem características vantajosas para diversos processos. Entre elas, uma pressão de vapor praticamente nula, alta estabilidade térmica, larga janela eletroquímica; além disso, a flexibilidade de suas propriedades de acordo com o ânion e tamanho da cadeia alquídica fazem com que esta classe de compostos seja bastante versátil. Outro grande ponto de interesse destes líquidos iônicos é a capacidade de serem utilizados como suportes, especialmente em catálise bifásica. ${ }^{38}$

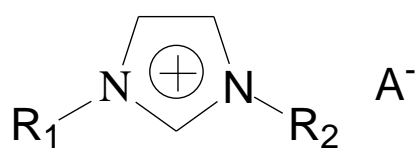

Figura 7. Exemplos de líquidos iônicos derivados do cátion 1,3-dialquilimidazólio $\left(\mathrm{R}_{1}\right.$,

$$
\mathrm{R}_{2}=\text { grupos alquila } \mathrm{A}^{-}=\mathrm{BF}_{4}^{-}, \mathrm{PF}_{6}^{-}, \mathrm{NTf}^{-} \text {, etc.) }
$$

Informações importantes acerca da estrutura dos líquidos iônicos derivados do cátion 1,3-dialquilimidazólio foram obtidas a partir do estudo desse material no estado sólido utilizando difração de raios $\mathrm{X}$. Os resultados obtidos levaram à conclusão de que os sais do cátion dialquilimidazólio possuem estrutura característica de rede de cátions e ânions ligados por meio de ligações hidrogênio. Além disso, a sua unidade monomérica é constituída de um cátion imidazólio envolvido por pelo menos três ânions e, ao redor de cada ânion, estão pelo menos três cátions (Figura 8a, adaptada da referência 39). ${ }^{39} \mathrm{O}$ arranjo tridimensional dos cátions imidazólio gera canais onde os ânions são acomodados (Figura 8b, adaptada da referência 37). Tal estrutura pode sofrer modificações dependendo do tamanho dos grupos alquila e dos ânions. 

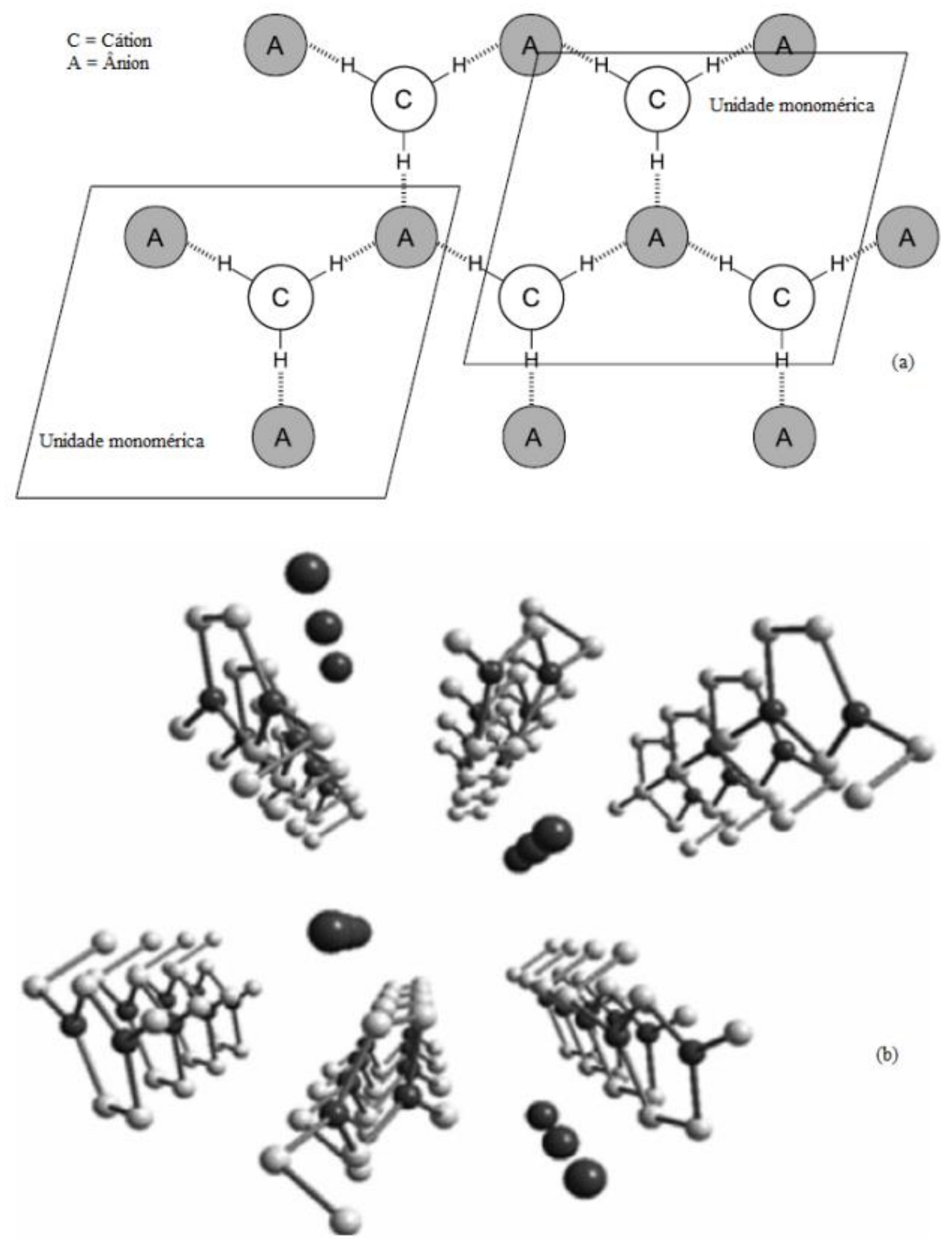

(b)

Figura 8. (a) Representação do arranjo 2D de líquidos iônicos imidazólicos; (b) visão esquemática do arranjo 3D dos cátions dialquilimidazólicos mostrando os canais nos quais os ânions "esféricos" são acomodados

Essas mudanças de estrutura também têm efeitos importantes nas propriedades físico-químicas do sal. Um estudo do efeito da variação do número de carbonos da cadeia alquídica na posição 1 do anel imidazólio mostrou que, quanto maior esse número, menor o ponto de fusão do líquido iônico. A explicação para este comportamento está fundamentada no aumento de graus internos de liberdade rotacional 
com o aumento da cadeia. Porém observa-se que, a partir de 12 carbonos, a formação de mesofases é notada devido à formação de interações fracas do tipo dipolo induzido entre as cadeias carbônicas, formando sistemas altamente organizados, que levam a um aumento do ponto de fusão. ${ }^{37}$

\subsubsection{Uso de líquidos iônicos em catálise}

Os líquidos iônicos possuem a capacidade de serem utilizados como suportes para catalisadores organometálicos, estabelecendo sistemas reacionais bifásicos em que o catalisador pode manter suas características químicas similares às de processos homogêneos. Além de melhorar o contato entre o substrato e o catalisador, eles podem manter inalteradas as propriedades moleculares de complexos, de modo que os catalisadores se comportam de forma muito similar aos sistemas homogêneos. ${ }^{38-40}$

A organização estrutural dos líquidos iônicos é apontada como o principal motivo pelo qual seu emprego em catálise tem fornecido ótimos resultados: as cadeias iônicas geram partes hidrofóbicas e/ou hidrofílicas tridimensionalmente. Isso faz com que vários tipos de catalisadores possam ser acomodados no interior dos canais do líquido iônico em geometrias que fornecem um ambiente químico adequado.

Quando utilizados em catálise bifásica, o catalisador, na maioria dos casos, se fixa à fase do líquido iônico, fazendo com que a separação dos produtos e do catalisador seja facilitada e, com isso, possibilitando o reaproveitamento do sistema catalítico ao final das reações. Porém, é necessário empregar ligantes que possibilitem uma melhor retenção dos metais na fase iônica, reduzindo problemas relacionados à lixiviação. ${ }^{41}$

Outro ponto interessante sobre esta classe de compostos é o chamado "efeito do líquido iônico". Este termo está associado à capacidade de estabilizar vários intermediários de reação ou os estados de transição, de modo que o uso de líquidos iônicos geralmente favorece a velocidade de reação e/ou aumenta a seletividade para um determinado produto. Estes efeitos podem ser atribuídos à natureza iônica inerente aos líquidos iônicos e auto-organização promovida por eles. Isto conduz à formação e estabilização de intermediários iônicos ou polares através de diferentes tipos de emparelhamentos de íons e formação de agregados supramoleculares, resultando em uma nano-organização espontânea do sistema. Assim, estes sais podem agir como direcionadores entrópicos para o sistema. ${ }^{39}$ 


\subsubsection{Caráter "não inocente" dos líquidos iônicos}

Os líquidos iônicos estão inclusos na classe dos solventes verdes, ou seja, apresentam pouco ou nenhum impacto ambiental. Porém, nos últimos anos, diversos estudos têm mostrado que esta característica é questionável. A presença de cátions imidazólicos ou piridínicos e ânions contendo cloroaluminato e hexafluorofosfato e seus produtos de decomposição podem comprometer as características não tóxicas do líquido iônico. ${ }^{42}$

Costuma-se também supor que esses líquidos atuem como solventes totalmente inertes e não coordenantes. Entretanto, em diversos exemplos, esse tipo de comportamento nem sempre foi observado e certo grau de cuidado deve ser tomado quando os líquidos iônicos são empregados em catálise. Apesar dos líquidos iônicos derivados do cátion 1,3-dialquilimidazólio serem estáveis na presença de muitas substâncias orgânicas e inorgânicas, tanto o cátion quanto o ânion podem sofrer transformações indesejáveis quando empregados em certas condições reacionais. Em alguns casos, os cátions e ânions desses líquidos podem facilmente sofrer hidrólise, especialmente os que contêm $\mathrm{AlCl}_{4}{ }^{-}$e $\mathrm{PF}_{6}{ }^{-}$. No caso do hexafluorofosfato, os seus produtos de hidrólise são os íons fosfato e o HF. A hidrólise do $\mathrm{PF}_{6}$ pode ser mais acentuada em reações que envolvem metais, que podem catalisar esta decomposição. ${ }^{43}$

Por sua vez, a reatividade de cátions imidazólio resulta principalmente da acidez relativamente alta $(\mathrm{pKa}=21-23)$ do hidrogênio ligado ao carbono entre dois nitrogênios do anel imidazólico, cuja desprotonação no cátion imidazólio gera ligantes do tipo carbeno N-heterocíclico (NHC), conforme demonstrado na Figura 9. ${ }^{44}$

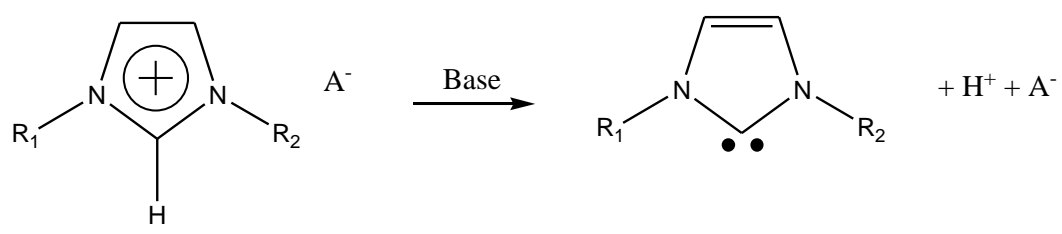

Figura 9. Reatividade dos cátions imidazólicos para formação de carbenos NHC.

Atualmente, diversos estudos têm descrito o uso de ligantes NHC, de forma que eles já possuem aplicações bem estabelecidas na literatura. Pesquisadores estão buscando cada vez mais entender os detalhes do comportamento dos NHCs como 
ligantes, assim como as ligações metal-NHC. Com isso, é possível uma melhor compreensão das peculiaridades de complexos com esta classe de ligante. ${ }^{45}$

Em um estudo publicado por Chen e colaboradores, dois complexos NHC imidazólicos atuaram como espécies catalíticas ativas para a hidroformilação, formando produtos com alta seletividade para o isômero ramificado (> 95:5) quando vinil arenos são usados como substratos (Figura 10, adaptada da referência 45). ${ }^{45}$ Exemplos como este demonstram que, quando são empregados líquidos iônicos em condições alcalinas, a formação de carbenos é muito provável de acontecer. Contudo, nem sempre é possível afirmar se os carbenos formados terão efeitos benéficos ou não para o sistema reacional.

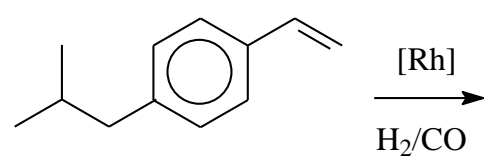

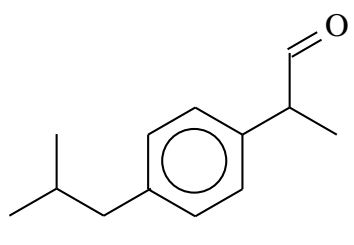

$97 \%$

$95 \%$ ramificado

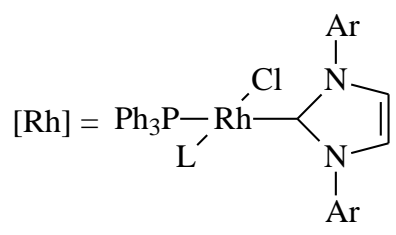

Ar

Figura 10. Hidroformilação de derivado de estireno com complexo de Rh/carbeno Nheterocíclico.

\subsection{Hidroformilação/hidroaminometilação}

Um procedimento muito comum utilizado para modificar moléculas insaturadas é a reação de hidroformilação. ${ }^{46-48}$ Este processo pode ocorrer em condições brandas, ocasionando a formação de aldeídos em uma reação com 100\% de economia de átomos, isto é, todos os átomos dos reagentes estão presentes no produto (Figura 2).

Inicialmente, a hidroformilação empregava precursores catalíticos contendo cobalto. No entanto, uma segunda geração de catalisadores de hidroformilação, com base em complexos de ródio, permitiu uma maior eficiência deste processo, além de atuar em condições ainda mais brandas de temperatura e pressão. Os aldeídos formados neste processo são compostos bastante reativos e versáteis que podem ser utilizados como material de partida para uma gama de produtos químicos, tais como álcoois, ácidos carboxílicos, aminas e éteres. ${ }^{49,50}$

O ciclo catalítico para a hidroformilação, apresentado na Figura 11, consiste em: (A) coordenação da olefina; (B) inserção da olefina em ligação metal-hidreto, sendo que a orientação mais estável para a coordenação é aquela na qual é formado um complexo 
com a olefina perpendicular à ligação M-H axial; (C) coordenação e inserção do CO na ligação metal-alquil, na qual é possível ocorrer tanto a migração do grupo alquila para o grupo cis-CO, como a migração do grupo cis-CO para o grupo alquila; (D) adição oxidativa do $\mathrm{H}_{2}$; (E) eliminação redutiva do aldeído para formar o produto final e regenerar a espécie catalítica ativa. ${ }^{51}$

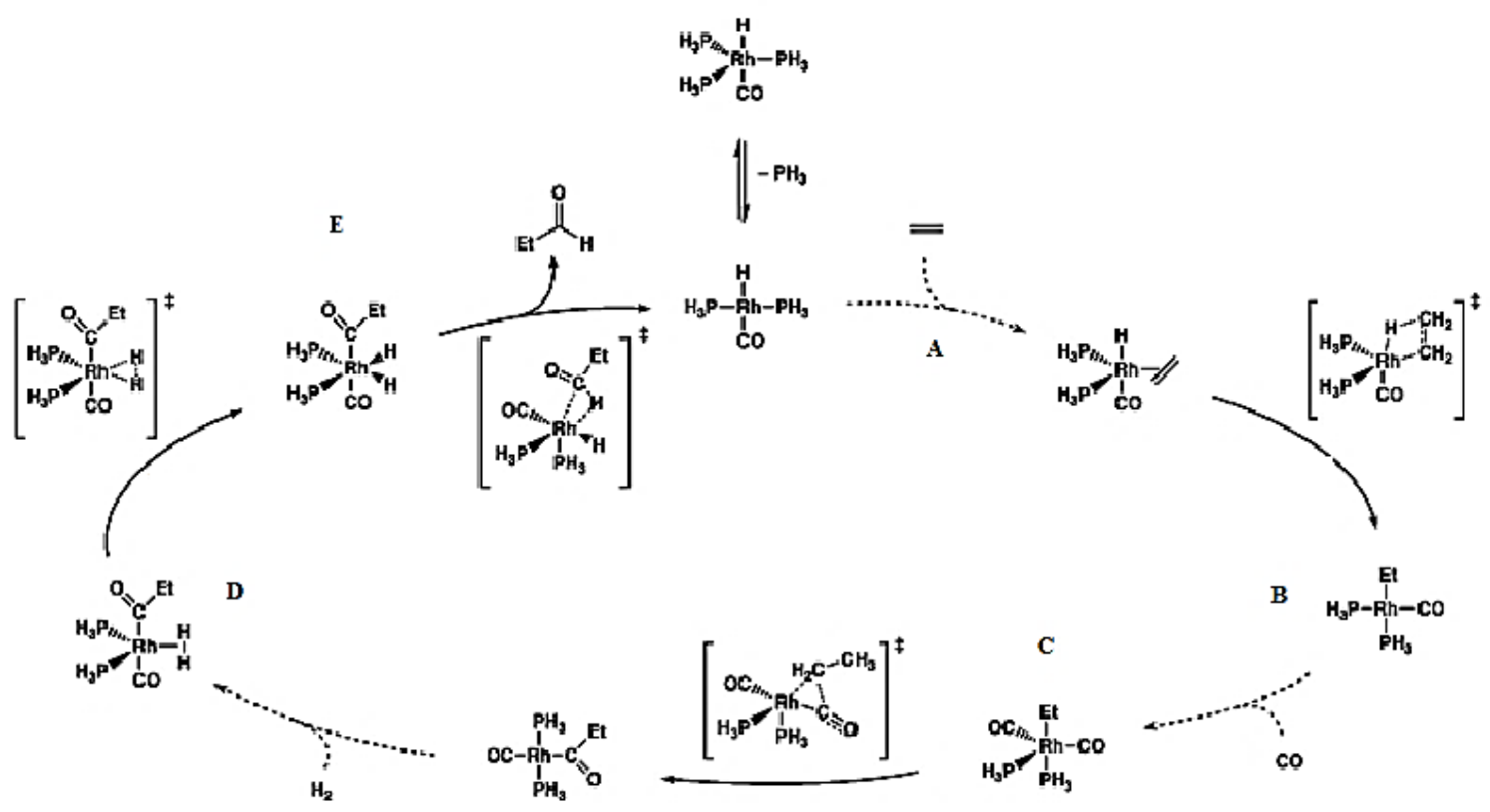

Figura 11. Ciclo catalítico para a hidroformilação (adaptada da referência 51).

Alquenos voláteis são usualmente hidroformilados em sistemas catalíticos homogêneos. Porém, estes sistemas apresentam desvantagens como operação descontínua e dificuldade de separação do catalisador da mistura reacional. Com o intuito de contornar estes problemas, vários autores têm utilizados sistemas nos quais os catalisadores podem estar adsorvidos na superfície de sólidos tais como carbonos ativados, ${ }^{52}$ nanotubos de carbono, $\mathrm{Al}_{2} \mathrm{O}_{3}, \mathrm{SiO}_{2}$, ,zeólitas e polímeros. ${ }^{53-56}$

Entretanto, observa-se que a maioria destes casos não representa um sistema verdadeiramente heterogêneo, pois o metal é removido do suporte original e a reação ocorre em meio homogêneo, produzindo espécies catalíticas in situ associadas à lixiviação do catalisador. Por outro lado, quando o catalisador é de fato imobilizado na superfície sólida, sua estrutura é frequentemente alterada, o que pode diminuir sua atividade e seletividade. Além disso, a baixa área superficial ativa e a dificuldade de acesso aos sítios ativos (dificuldade esta observada principalmente para substratos 
grandes) podem comprometer a velocidade de reação. Mesmo assim, os problemas relacionados à lixiviação do catalisador ainda persistem. ${ }^{41}$

Recentemente, alguns autores têm relatado o emprego de nanopartículas de $\mathrm{Rh}$ na hidroformilação de alcenos. Bruss et al. dispersaram as nanopartículas em um sistema bifásico, separando as fases ao final da reação por simples decantação. ${ }^{58}$ Por sua vez, o grupo de Wang dispersou as nanopartículas em um sistema catalítico baseado em polietilenoglicol ${ }^{59,60}$ e no líquido iônico $\left[\mathrm{CH}_{3}\left(\mathrm{OCH}_{2} \mathrm{CH}_{2}\right)_{16} \mathrm{Et}_{3} \mathrm{~N}^{+}\right]\left[\mathrm{CH}_{3} \mathrm{SO}_{3}{ }^{-}\right] .{ }^{61}$ Assumiuse que, durante a reação, as nanopartículas coloidais do $\mathrm{Rh}(0)$ passam para a forma de complexos solúveis de $\mathrm{Rh}$ ativos, de modo semelhante como acima relatado para o catalisador adsorvido em uma superfície sólida. É claro que, uma vez que o Rh migra para a solução, parte dele não é recuperada.

Outra abordagem para contornar as desvantagens citadas é a utilização de sistemas bifásicos nos quais o catalisador é imobilizado em uma fase polar ou iônica. Uma vez que o catalisador e os produtos estão em duas fases imiscíveis diferentes, eles podem ser facilmente separados. A forma mais óbvia e mais econômica de utilizar um solvente que forme um sistema bifásico com compostos orgânicos de baixa polaridade é empregar a água. De fato, ela é usada em vários processos industriais. ${ }^{62,63}$ No entanto, a baixa solubilidade dos substratos de cadeia média e longa em água limita a transferência de massa e, consequentemente, as taxas de reação.

Uma alternativa interessante foi desenvolvida por Arhancet e colaboradores e mais tarde utilizado por outros autores. ${ }^{64,65}$ Eles suportaram os catalisadores em uma superfície hidrofílica de um sólido poroso com elevada área superficial (SAPC supported aqueous phase catalyst), de modo que os problemas relacionados à solubilidade dos substratos foram contornados por causa de um aumento na interface entre as fases aquosa e orgânica. No entanto, problemas com lixiviação também limitam a aplicação dos SAPC.

Uma vez que a solubilidade de alquenos é maior em líquidos iônicos do que em água, os líquidos iônicos mostraram-se mais adequados para a imobilização de catalisadores em sistemas catalíticos bifásicos destinados à hidroformilação de substratos de cadeia média e longa. Muitos trabalhos referentes à hidroformilação de alquenos em sistemas catalíticos bifásicos baseados em líquidos iônicos foram relatados durante as últimas duas décadas. ${ }^{66,67}$ Embora tenham sido alcançados avanços significativos, a combinação de alta atividade, retenção completa do catalisador no líquido iônico e elevada seletividade para o produto de hidroformilação desejado ainda é 
um grande desafio. Além disso, a maior parte das reações de hidroformilação relatados na literatura referem-se a alquenos terminais monoinsaturados. No entanto, sabe-se que a reatividade para a hidroformilação é drasticamente menor para alquenos internos em comparação com os terminais. ${ }^{68}$

Com relação ao aspecto estrutural, os EAGs são geralmente constituídos por alquenos internos de cadeia longa, incluindo moléculas poli-insaturadas, característica esta bem observada quando soja é usada como matéria-prima. No que diz respeito à hidroformilação de EAGs ou óleos vegetais, são poucos os trabalhos encontrados na literatura. A maior parte deles foi realizado utilizando sistemas catalíticos homogêneos ${ }^{69,70}$ ou adsorvidos. ${ }^{54,71}$ As exceções são dois estudos realizados em sistemas catalíticos bifásicos à base de água: (i) Fell e colaboradores ${ }^{72}$ utilizaram surfactantes para aumentar a solubilidade do EMAG em fase aquosa e (ii) Boulanger et al. demonstraram que os carbonos ativados mesoporosos são capazes de melhorar a transferência de massa, porque a fase aquosa e o EMAG seriam supostamente confinados nos poros, resultando em melhor contato entre o catalisador e o substrato. ${ }^{72}$

Em outro exemplo, Panda et al. converteram acrilatos de metila em seus correspondentes aldeídos utilizando um catalisador à base de $\mathrm{Rh}$ suportado em uma fase com líquido iônico na presença de água no meio reacional. ${ }^{73}$ No entanto, é importante salientar que tais substratos de cadeia curta apresentem propriedades bastante diferentes de solubilidade, o que influencia profundamente o perfil da reação. Notavelmente, o metil-3-pentenoato é tão solúvel no líquido iônico que foi possível afirmar que a reação de hidroformilação ocorreu em meio homogêneo. Além disso, a ligação $\mathrm{C}=\mathrm{C}$ de acrilatos é conjugada com a ligação $\mathrm{C}=\mathrm{O}$ do grupo carboxila, o que induz significativas diferenças de reatividade.

Se a hidroformilação é realizada na presença de aminas primárias ou secundárias, é observada a formação de produtos nitrogenados resultantes de reações de condensação da amina utilizada com o aldeído resultante da hidroformilação. O termo hidroaminometilação refere-se a uma reação do tipo "one-pot” na qual ocorre uma reação de hidroformilação seguida por uma aminação redutiva. Como a água é o único subproduto desta reação, o processo representa uma forma eficiente de produzir aminas. A adição nucleofílica da amina ao aldeído formado gera $O, N$-semiacetais, que na sequência sofrem desidratação para formar imina (se amônio ou uma amina primária forem empregados) ou enamina (se uma amina secundária for empregada). 
Como a hidroformilação é realizada na presença de $\mathrm{H}_{2}$ e o catalisador utilizado normalmente é ativo também para a hidrogenação, a imina ou enamina podem sofrer redução para formar aminas primárias, secundárias ou terciárias. ${ }^{74}$ A reação global de hidroaminometilação de um alceno está representada na Figura 3.

Líquidos iônicos foram empregados nas reações de hidroaminometilação de olefinas de cadeia longa $\left(\mathrm{C}_{6}-\mathrm{C}_{12}\right)$ utilizando piperidina como substrato nitrogenado e um complexo de $\mathrm{Rh}$ em líquido iônico imidazólico. ${ }^{75}$ Os resultados mostraram que a utilização de líquidos iônicos propiciou uma grande diminuição na formação de produtos de reações laterais quando comparado com o mesmo sistema utilizando metanol e tolueno como solventes.

\subsection{Modificações químicas das moléculas de biodiesel}

Sabe-se que o alto grau de insaturação do biodiesel de soja está associado à baixa estabilidade oxidativa deste combustível. Para contornar este problema, Carvalho et al. ${ }^{10}$ realizaram a hidrogenação de ligações duplas. Utilizando um sistema reacional

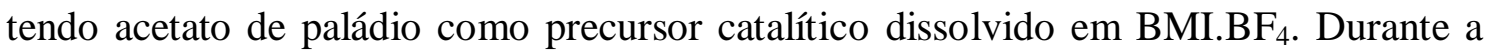
reação, foram geradas nanopartículas de paládio in situ, as quais foram estabilizadas pelo liquido iônico e foram, supostamente, as responsáveis pela hidrogenação. Uma característica importante deste sistema é que a hidrogenação aconteceu de forma seletiva, com os ésteres metílicos poli-insaturados sendo parcialmente hidrogenados para gerar os ésteres monoinsaturados. Isto ocorreu devido a uma maior solubilidade dos compostos poli-insaturados no liquido iônico em relação à solubilidade dos ésteres monoinsaturados, resultando numa composição em que o éster metílico do ácido oleico foi gerado a partir da hidrogenação dos EMAGs poli-insaturados. O mecanismo proposto nesta reação é mostrado na Figura 12. Além disso, houve a possibilidade de reciclo do sistema reacional por meio da simples remoção da fase orgânica após a reação e adição de uma nova carga do composto de partida. ${ }^{10}$ 


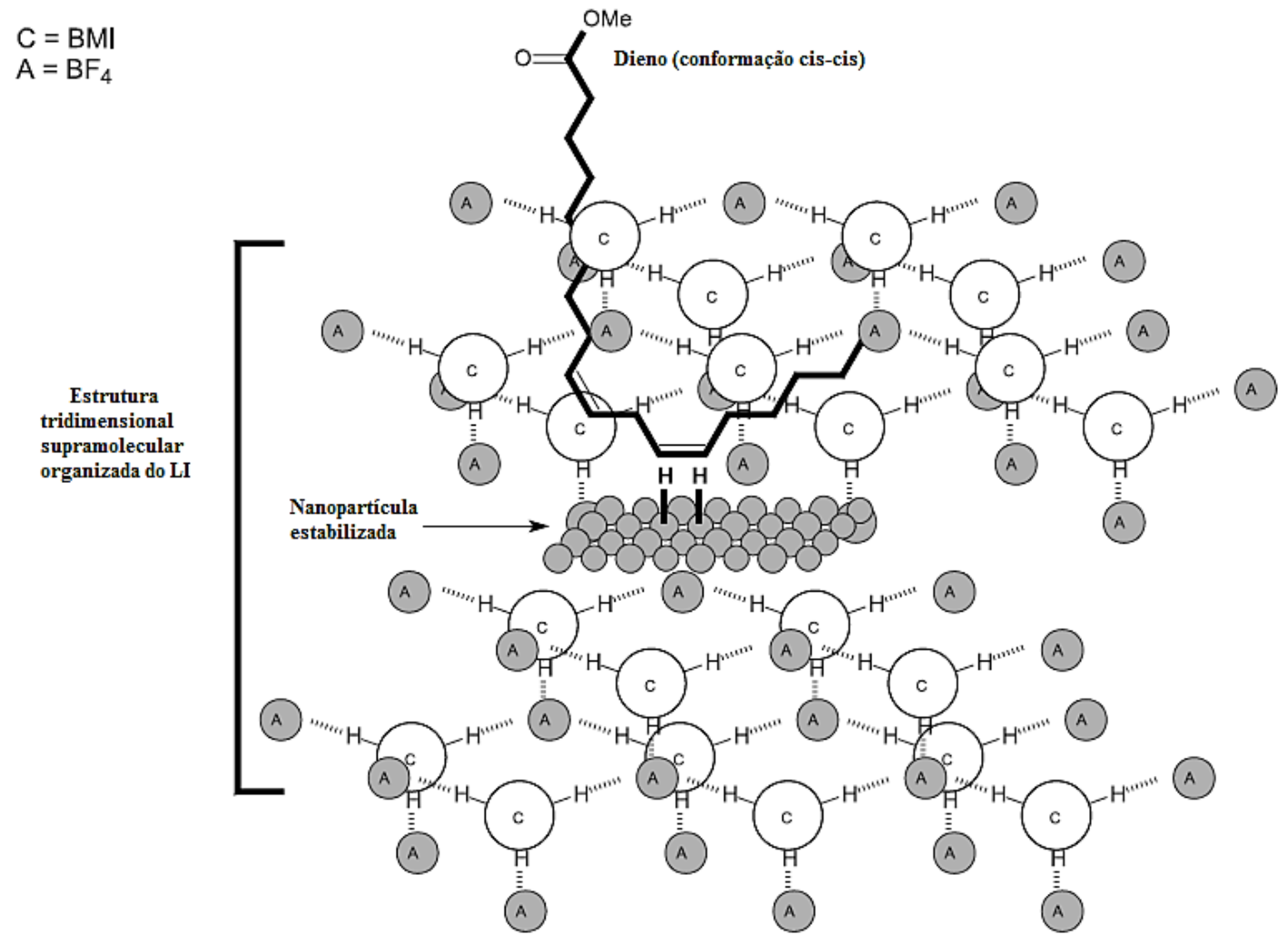

Figura 12. Mecanismo para hidrogenação seletiva de biodiesel (referência 12).

Também com o objetivo de diminuir a quantidade de ligações duplas e aumentar a estabilidade oxidativa, Neto et al. testaram nove enzimas comercialmente disponíveis para promover a epoxidação do oleato de metila comercial utilizando peróxido de hidrogênio como agente oxidante. Neste trabalho, os líquidos iônicos utilizados

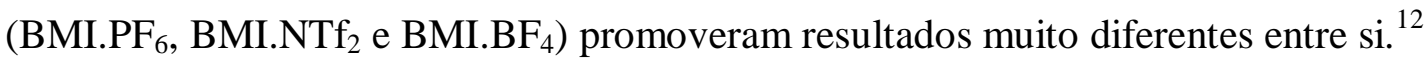

Quando o líquido iônico usado era hidrofóbico $\left(\mathrm{BMI}_{\mathrm{PF}} \mathrm{F}_{6} \text { e } \mathrm{BMI.NTf}\right)_{2}$, o produto formado em maior quantidade foi o epóxido do oleato de metila (EOM, Figura 13). No BMI.PF 6 , os melhores resultados foram obtidos com a enzima Amano $\mathrm{K}$ (Penicillium roqueforti), que resultou em $82 \%$ de EOM na quinta hora de reação. Já com o BMI.NTf 2 , os melhores resultados foram obtidos com a enzima lipase tipo II, resultando em 78\% de EOM em apenas $1 \mathrm{~h}$ de reação. Para ambos os casos, houve uma baixa formação de DIOL resultante da abertura do anel oxirano. O estudo do líquido iônico hidrofílico $\mathrm{BMI} \mathrm{BF}_{4}$ apresentou $89 \%$ de EOM foi obtido em apenas $1 \mathrm{~h}$ de reação utilizando a enzima Amano A (Aspergillus niger). Depois desse tempo, houve um aumento da quantidade de DIOL devido ao caráter hidrofílico do líquido iônico empregado. $^{11}$ 


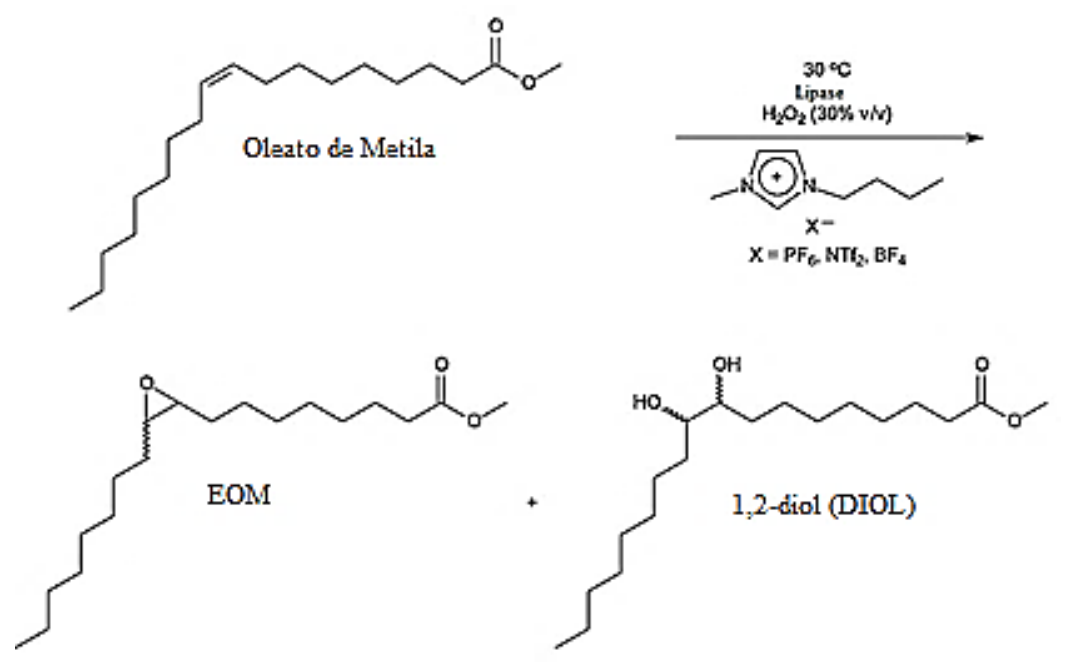

Figura 13. Reação de epoxidação de oleato de metila (referência 12).

A reação de hidroformilação também foi empregada para modificação de biodiesel de soja ${ }^{70}$ e mamona. ${ }^{76}$ Em alguns trabalhos, foi empregado o precursor catalítico $\mathrm{HRh}(\mathrm{CO})\left(\mathrm{PPh}_{3}\right)_{3}$ em condições brandas de pressão e temperatura. Reações de hidroformilação foram realizadas com oleato de metila grau técnico e óleo de soja usando $\mathrm{RhH}(\mathrm{CO})\left(\mathrm{PPh}_{3}\right)_{3}$ e $\mathrm{RhCl}_{3} \cdot 3 \mathrm{H}_{2} \mathrm{O}$ (ligação dupla/ $\mathrm{Rh}=745$ ) como precursores catalíticos, com adição ou não de $\mathrm{PPh}_{3}$ ao sistema. O complexo $\mathrm{RhH}(\mathrm{CO})\left(\mathrm{PPh}_{3}\right)_{3}$ levou a $100 \%$ de conversão e $80-91 \%$ de produtos hidroformilados em $4 \mathrm{~h}$ para ambos substratos, sob condições reacionais brandas $\left(100{ }^{\circ} \mathrm{C}, 40 \mathrm{bar}, \mathrm{CO} / \mathrm{H}_{2}=2: 1\right.$, ligante $/ \mathrm{Rh}=$ 10:1), sem utilização de líquido iônico.

A utilização de líquidos iônicos para modificação de EMAG via hidroformilação foi empregada pela primeira vez por Ramalho e colaboradores. ${ }^{14} \mathrm{O}$ precursor catalítico empregado foi também o $\mathrm{HRhCO}\left(\mathrm{PPh}_{3}\right)_{3}$, que foi dissolvido em $\mathrm{BMI} \mathrm{PF}_{6}$. Este trabalho demonstrou que o líquido iônico atuou na estabilização do complexo metálico ativo para a hidroformilação, promovendo um aumento de conversão e seletividade para a formação de aldeídos quando comparado a reações sem a presença do líquido iônico, chegando a alcançar $100 \%$ de conversão de ligações duplas para aldeídos após $8 \mathrm{~h}$ de reação. Para tempos de reações muito longos, foi observado que os aldeídos formados sofreram reações consecutivas, as quais foram atribuídas à formação de nanopartículas de ródio no meio reacional, que foram observadas por imagens de microscopia de força atômica. 
No mesmo trabalho, verificou-se que a adição de um excesso do ligante $\mathrm{PPh}_{3}$ no meio reacional promoveu um aumento da seletividade e da taxa de reação para a formação de aldeídos. Além disso, este excesso de ligante evitou que houvesse a formação de nanopartículas de ródio, o que diminuiu drasticamente o consumo dos aldeídos formados. Logo, os resultados indicaram que a espécie catalítica ativa para a hidroformilação deve ser um complexo contendo o ligante $\mathrm{PPh}_{3}$, enquanto as nanopartículas de ródio, apesar de também serem ativas para a hidroformilação, podem catalisar também reações paralelas e/ou consecutivas como hidrogenação e descarboxilação. ${ }^{19,78}$

A utilização de líquidos iônicos como suporte para ácidos de Brønsted e de Lewis foi testada para a obtenção de derivados em que, em vez da ligação dupla, o grupo éster do oleato de metila sofreu alteração. Por meio da reação de aminólise, foi possível obter amidas de ácido oleico com características biocidas. Quando a reação foi realizada sem o emprego de líquidos iônicos (sem solvente ou em solventes orgânicos convencionais), foram alcançados rendimentos apenas moderados, mesmo após longos tempos reacionais. Porém, todos os líquidos iônicos testados (BMI.NTf 2, BMI.PF $_{6}$ e BMI $\mathrm{BF}_{4}$ ) resultaram em rendimentos quantitativos quando o catalisador usado foi o $\mathrm{BF}_{3} . \mathrm{OEt}_{2}(5 \% \mathrm{em} \mathrm{mol}){ }^{12}$

Embora todos os líquidos iônicos tenham apresentado ótimos resultados, enfoque especial foi dado às reações com BMI.Ntf 2 , para evitar uma possível degradação por hidrólise dos ânions $\mathrm{PF}_{6}{ }^{-}$e $\mathrm{BF}_{4}{ }^{-}$. Como não é possível reciclar o catalisador $\mathrm{BF}_{3} \mathrm{OEt}_{2}$, os autores optaram por utilizar catalisadores que pudessem ser reciclados, justificando a escolha dos óxidos metálicos de estanho e cádmio para realizar esta transformação. Ambos foram utilizados pelo menos oito vezes sem perda de atividade.

O mecanismo proposto para esta transformação mostra que o estado de transição passa por uma estrutura na forma de um anel de seis membros. Por isto, um excesso de amina deve ser utilizado (Figura 14 (a)). Além disso, a ativação da ligação $\mathrm{C}=\mathrm{O}$ acontece por um mecanismo cooperativo entre o líquido iônico e o catalisador (Figura 14(b)). Assim, o líquido iônico tem um papel fundamental na reação, que vai além de ser um simples suporte para os catalisadores, tendo também a função de estabilizar intermediários polares e carregados, além de ativar parcialmente o grupo carbonila do substrato. 
A hidroaminometilação de oleato de metila em presença de diferentes aminas foi realizada por Yemashova et al. em sistemas catalíticos homogêneos, com diferentes solventes orgânicos, com o precursor catalítico [RhcodCl] $(\operatorname{cod}=$ ciclo-octadieno $)$, sendo obtidos rendimentos variando entre 47 e $97 \%$. Quando foi utilizado um excesso do derivado de ácido oleico, observou-se também a formação de produtos resultantes da condensação entre duas moléculas de oleato de metila, com a amina atuando como ponte (Figura 15). ${ }^{9}$ Porém, quando foram usadas quantidades equimolares de amina e oleato, as aminas em ponte não foram observadas.

(a)

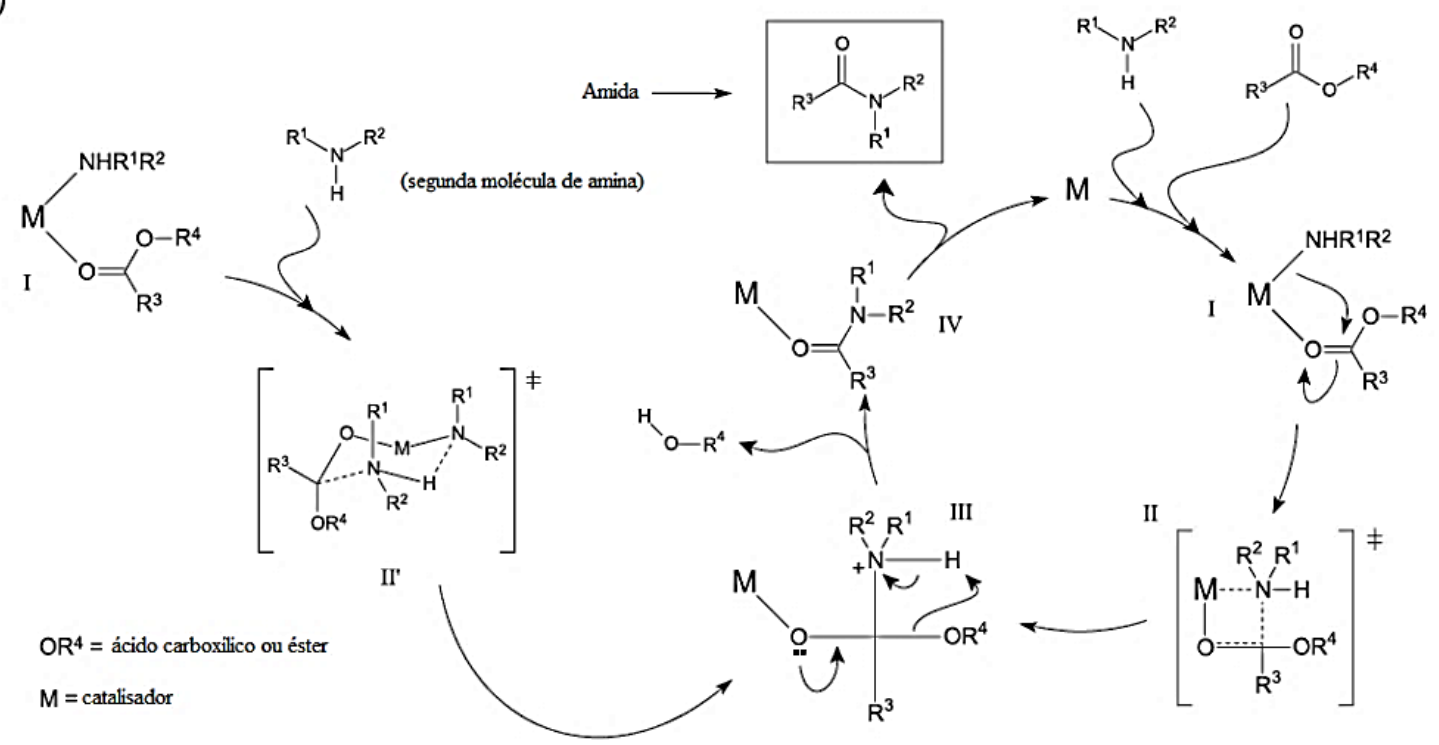

(b)
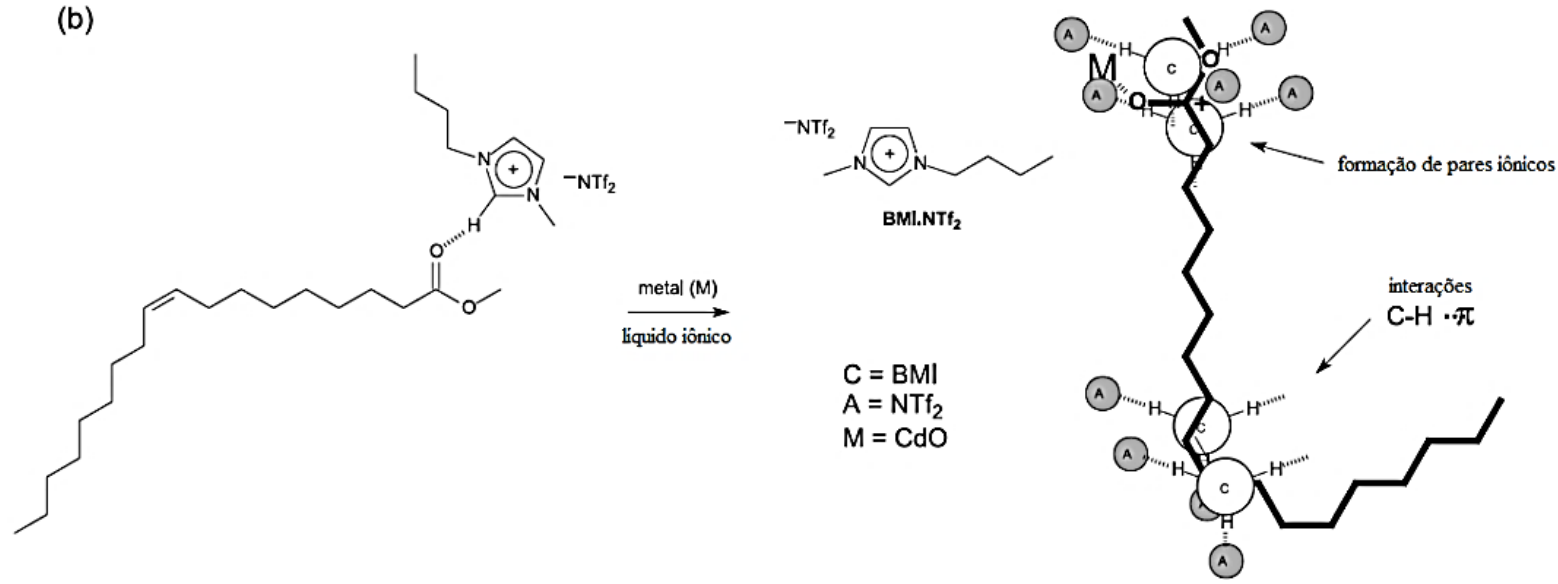

Figura 14. (a) Mecanismo de reação da aminólise; (b) Mecanismo de ativação do grupo $\mathrm{C}=\mathrm{O}$. 
A hidroaminometilação de oleato de metila em presença de diferentes aminas foi realizada para obter substâncias com potencial poder surfactante. As reações foram realizadas em sistemas catalíticos homogêneos, com diferentes solventes orgânicos, com o precursor catalítico $[\mathrm{RhcodCl}](\operatorname{cod}=$ ciclooctadieno $)$, sendo obtidos rendimentos variando entre 47 e $97 \%$. Quando foi utilizado um excesso do derivado de ácido oleico, observou-se também a formação de produtos resultantes da condensação entre duas moléculas de oleato de metila, com a amina atuando como ponte (Figura 15) ${ }^{78}$ Porém, quando foram usadas quantidades equimolares de amina e oleato, as aminas em ponte não foram observadas.

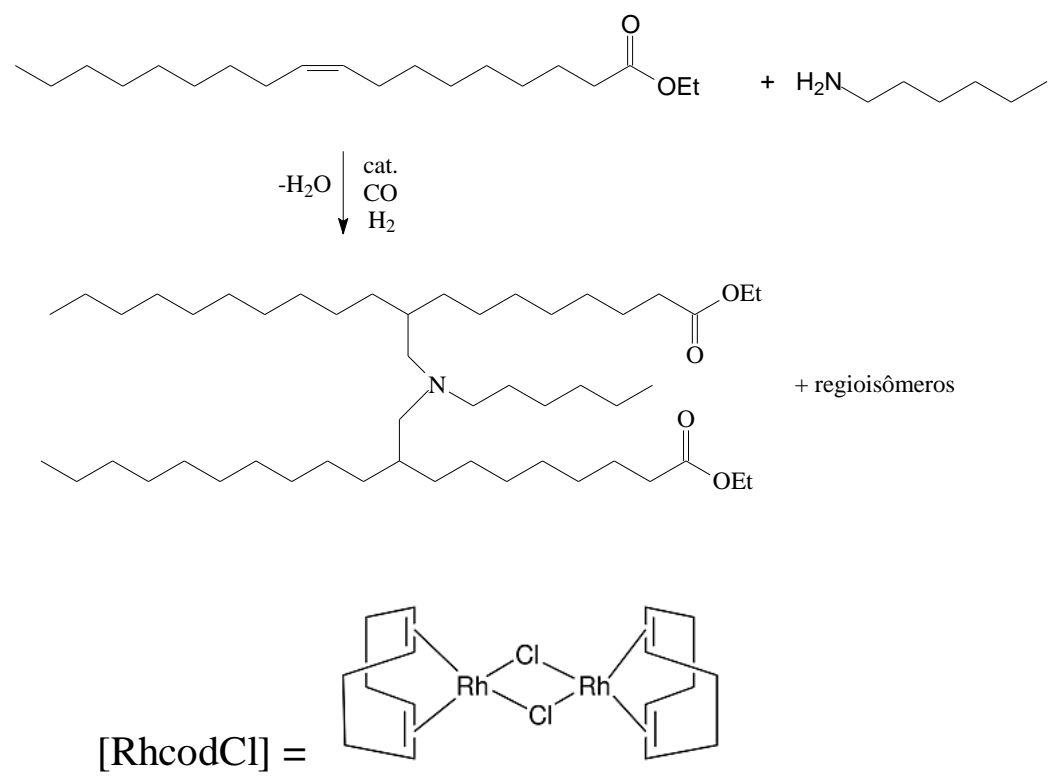

Figura 15. Ligação entre duas moléculas de oleato de etila através de uma amina atuando como ponte. 
CAPÍtulo 3

METODOLOGIA 


\subsection{Reagentes}

O precursor catalítico $\mathrm{HRhCO}\left(\mathrm{PPh}_{3}\right)_{3}$ (Sigma-Aldrich), metanol (Cromoline), hidróxido de potássio (Vetec), trifenilfosfina (Sigma-Aldrich), $\mathrm{H}_{2}$ (White Martins 99,9\%), $\mathrm{CO}$ (White Martins, 99\%), $\mathrm{MgSO}_{4}$ (Sigma-Aldrich), cloreto de metanossulfonila (Sigma-Aldrich), trietilamina (VETEC), diclorometano (Cromoline) e o hexafluorofosfato de potássio (Sigma-Aldrich) foram usados sem prévia purificação. O óleo de soja refinado (Bunge) foi sob pressão reduzida antes do seu uso. A $n$ butilamina (Sigma-Aldrich) e o metilimidazol (Sigma-Aldrich) foram destilados antes do uso.

\subsection{Síntese do biodiesel de soja (EMAG)}

Antes de sofrer transesterificação, $150 \mathrm{~g}$ de óleo de soja comercial foram secados sob pressão reduzida em um balão do tipo Schlenk. Em outro balão, foi colocada uma massa de $\mathrm{KOH}$ correspondente a $1 \%$ da massa de óleo de soja (1,5 g), que foi dissolvida em $40 \mathrm{~mL}$ de metanol, gerando o metóxido de potássio. A solução de metóxido de potássio foi adicionada ao óleo de soja seco e a mistura reagiu em agitação magnética vigorosa por $2 \mathrm{~h}$ à temperatura ambiente em atmosfera inerte de $\mathrm{N}_{2}$.

Após o final da reação, foram observadas duas fases: uma fase contendo glicerina, metanol e $\mathrm{KOH}$ (fase inferior), de cor castanha, e outra contendo biodiesel (fase superior), de cor amarela. As fases foram separadas utilizando um funil de separação e a fase glicerinosa foi descartada. O produto da fase superior foi lavado diversas vezes com água destilada para retirada de traços de catalisador, glicerina e metanol. Depois de lavado, o biodiesel foi secado com $\mathrm{MgSO}_{4}$ anidro, filtrado em uma coluna de alumina básica em atmosfera de $\mathrm{N}_{2}$ e secado novamente sob pressão reduzida. É importante destacar que o produto foi mantido sempre em atmosfera inerte durante o seu manuseio e armazenado no congelador, evitando uma possível degradação. A conversão de óleo de soja em biodiesel foi monitorada por cromatográfica líquida de alta eficiência (CLAE). ${ }^{79}$ 


\subsection{Síntese hexafluorofosfato de 1-n-butil-3-metil-imidazólio (BMI.PF $)$}

O líquido iônico hexafluorofosfato de 1-n-butil-3-metil-imidazólio (BMI.PF $\left.{ }_{6}\right)$ foi sintetizado em três etapas, de acordo com procedimento descrito na literatura. ${ }^{80}$

\section{- Etapa 1: Preparação do butilmetanossulfonato}

Inicialmente, foi preparada uma solução contendo n-butanol $(118,40 \mathrm{~g}, 1,60$ mol) e trietilamina $(161,60 \mathrm{~g}, 1,60 \mathrm{~mol})$ em 1,5 L de diclorometano. A esta solução adicionaram-se 183,20 g (1,60 mol) de cloreto de metanossulfonila com a utilização de um funil de adição, procedimento este realizado em banho de gelo. Durante a adição, observou-se a formação de cristais brancos que correspondem ao sal cloreto de trietilamônio. Após o término da adição, retirou-se o banho de gelo, deixando a reação ocorrer por mais $2 \mathrm{~h}$. Em seguida, a mistura final foi lavada diversas vezes com água destilada, até que não fosse mais observada a presença de cloreto (detectado pelo teste com solução aquosa de $\mathrm{AgNO}_{3}$ ).

Depois da lavagem, o excesso de diclorometano foi removido com pressão reduzida em um evaporador rotatório e o produto obtido foi destilado a vácuo $\left(\sim 85^{\circ} \mathrm{C}\right)$. Após a destilação, o produto da reação foi adicionado a $70 \mathrm{~mL}$ de $n$-butanol e $110 \mathrm{~mL}$ de trietilamina e deixado em agitação por $24 \mathrm{~h}$ para garantir que todo o cloreto de metanossulfonila reagisse. A mistura obtida foi novamente destilada em pressão reduzida, obtendo-se, ao final, um líquido incolor que corresponde ao butilmetanossulfonato. A reação envolvida é apresentada na Figura 16.

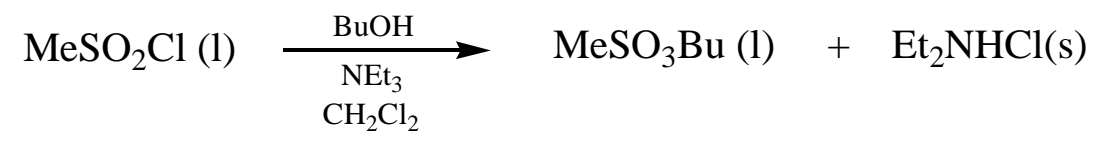

Figura 16.Síntese do butilmetanossulfonato.

\section{- Etapa 2: Síntese do metanossulfonato de 1-n-butil-3-metilimidazólio (BMI.MeSO$\left.{ }_{3}\right)$}

$\mathrm{O}$ BMI.MeSO 3 , foi obtido a partir da reação entre 241,90 g de butilmetanossulfonato (sintetizado na etapa anterior) com metilimidazol (130,47 g) previamente destilado (relação molar 1:1), por $24 \mathrm{~h}$, em temperatura ambiente sob 
agitação magnética vigorosa. Ao final da reação, um cristal de $\mathrm{BMI}^{\mathrm{M}} \mathrm{MeSO}_{3}$ foi adicionado a esta mistura reacional, que foi deixada em repouso por $72 \mathrm{~h}$ para cristalização. Após esta etapa, observou-se a formação de cristais brancos correspondentes ao $\mathrm{BMI}_{\mathrm{MeSO}} \mathrm{Me}_{3}$ (Figura 17). Este produto foi então recristalizado com acetona a quente e deixado no congelador por uma noite. Esta etapa de recristalização foi repetida três vezes. O produto final foi seco em pressão reduzida e mantido em atmosfera inerte de $\mathrm{N}_{2}$.

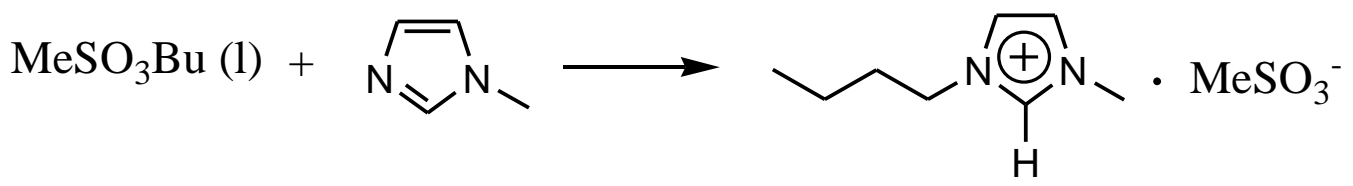

Figura 17.Síntese do BMI.MeSO 3 .

\section{- Etapa 3: Obtenção do líquido iônico BMI.PF 6}

Esta etapa consiste na simples troca do ânion $\mathrm{MeSO}_{3}{ }^{-}$do sal $\mathrm{BMI} \cdot \mathrm{MeSO}_{3}$ pelo ânion $\mathrm{PF}_{6}{ }^{-}$(Figura 18). Para realizar esta troca, adicionou-se a um béquer 109,9 g (470 mmol) de BMI.MeSO$_{3}$ (pesados sob atmosfera inerte de $\mathrm{N}_{2}$ ), 90,7 $\mathrm{g}$ de hexafluorofosfato de potássio $(493 \mathrm{mmol})$ e $250 \mathrm{~mL}$ de água destilada. Esta mistura foi mantida sob agitação vigorosa por $1 \mathrm{~h}$. A fase aquosa (inferior) foi então separada e descartada, enquanto a fase orgânica foi seca sob pressão reduzida, seca com $\mathrm{MgSO}_{4}$ anidro e filtrada a vácuo com uma coluna de alumina básica. Após este procedimento, obteve-se um líquido viscoso e incolor, que corresponde ao líquido iônico $\mathrm{BMI}_{\mathrm{PF}} \mathrm{PF}_{6}$ (confirmado por análise de $\mathrm{RMN}{ }^{1} \mathrm{H}$ ).

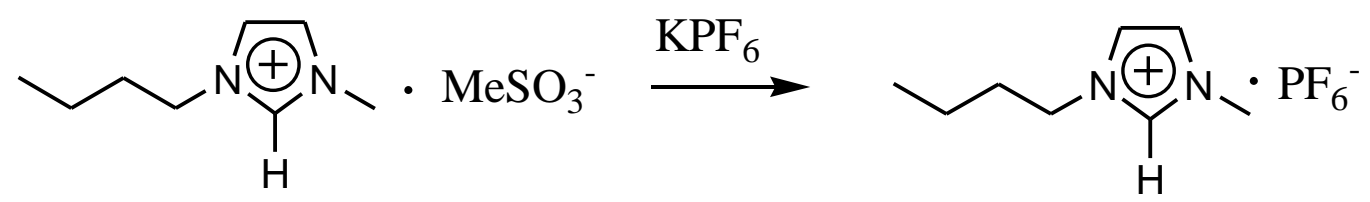

Figura 18. Síntese do $\mathrm{BMI}_{\mathrm{PF}}$. 


\subsection{Reações de hidroformilação em presença de $\boldsymbol{n}$-butilamina}

As reações de hidroformilação do biodiesel em presença de $n$-butilamina para obtenção dos compostos nitrogenados foram realizadas em um reator de aço inox selado de $100 \mathrm{~mL}$. De maneira geral, utilizou-se um sistema catalítico bifásico com o líquido iônico hexafluorofosfato de 1-butil-3-metilimidazólio; entretanto, para efeito de comparação, algumas reações foram realizadas sem a adição do líquido iônico.

Inicialmente, as quantidades desejadas do precursor catalítico $\mathrm{HRhCO}\left(\mathrm{PPh}_{3}\right)_{3} \mathrm{e}$ do ligante trifenilfosfina - $\mathrm{PPh}_{3}$ (quando empregado) foram dissolvidos em $4 \mathrm{~mL}$ no líquido iônico supracitado dentro do reator sob atmosfera inerte de $\mathrm{N}_{2}$ (o volume de líquido iônico correspondeu a 1/2 do volume de EMAG utilizado). Em seguida, foram adicionados $8 \mathrm{~mL}$ de EMAG e 9,6 $\mathrm{mL}$ de $n$-butilamina (relação molar entre as insaturações de biodiesel com a $n$-butilamina igual a 1:1). O reator foi então pressurizado com 40 bar de monóxido de carbono e hidrogênio na proporção 2:1. Após a pressurização, o sistema reagiu com aquecimento em banho de óleo $\left(100{ }^{\circ} \mathrm{C}\right) \mathrm{e}$ agitação vigorosa por diferentes intervalos de tempo.

Observou-se que, após o término da reação, o líquido iônico teve sua coloração alterada de acordo com as condições empregadas para a reação. $\mathrm{O}$ produto orgânico formado foi facilmente separado, permitindo o reaproveitamento da fase iônica para posteriores reações. Os produtos foram caracterizados por infravermelho e RMN ${ }^{1} \mathrm{H}$.

\subsection{Caracterização dos produtos}

O rendimento para a formação de biodiesel foi quantificada utilizando um cromatógrafo líquido CTO-20A da Shimadzu com detector UV/VIS operando a 205 nm, equipado com uma coluna Shim-Pack VP-ODS (C18, 250 mm, 4,6 mm de diâmetro interno). $\mathrm{O}$ volume de injeção foi de $10 \mu \mathrm{L}$ e o fluxo de $1 \mathrm{~mL} \mathrm{~min}^{-1}$. A temperatura da coluna foi mantida em $40{ }^{\circ} \mathrm{C}$. As amostras foram dissolvidas em 2-propanol:hexano $(5: 4, \mathrm{v} / \mathrm{v})$ e injetadas diretamente na coluna. Foi empregado um gradiente binário durante $20 \mathrm{~min}$, começando com $100 \%$ de metanol e $0 \%$ de 2-propanol:hexano (5:4, v/v) até alcançar a concentração de $50 \%$ de metanol e $50 \%$ de 2-propanol:hexano (5:4, v/v) no tempo de 10 min. Esta concentração foi então mantida até 20 min. $^{79}$

Os produtos das reações de modificação do biodiesel foram caracterizados por infravermelho, RMN ${ }^{1} \mathrm{H}$ e RMN ${ }^{13} \mathrm{C}$. Os espectros de ressonância magnética nuclear de 
hidrogênio $\left(\mathrm{RMN}{ }^{1} \mathrm{H}\right)$ foram obtidos em dois equipamentos: (i) um espectrômetro Anasazi modelo eft-60 de $60 \mathrm{MHz}$, sem diluição das amostras em solvente e com a adição de tetrametilsilano (TMS) como referência interna; (ii) um espectrômetro Bruker modelo Advance III HD $600 \mathrm{MHz}$, utilizando TMS como padrão interno e $\mathrm{CDCl}_{3}$ como solvente. Os espectros de RMN ${ }^{13} \mathrm{C}$ - APT (AttachedProton Test) foram obtidos utilizando um espectrômetro Varian modelo Mercury 300 operando a 75,5 MHz, utilizando $\mathrm{CDCl}_{3}$ como solvente.

Os espectros de infravermelho foram obtidos em um espectrômetro FT-IR modelo IR Prestige da Shimadzu utilizando uma célula modelo ATR Miracle que abrange a região de 650 a $4000 \mathrm{~cm}^{-1}$. Cada espectro foi obtido como resultado médio de 32 interferogramas, com resolução espectral de $4 \mathrm{~cm}^{-1}$.

O lixiviamento dos metais para a fase orgânica foi avaliado por meio de um equipamento de ICP-AES (inductively coupled plasma-atomic emission spectroscopy), da marca Termo Scientific, modelo ICAP 6000, utilizando o método de calibração externa.

\subsection{Cálculos de conversão, seletividade e rendimento}

Os cálculos de conversão, seletividade e rendimento para as reações realizadas foram feitos a partir dos espectros de $\mathrm{RMN}{ }^{1} \mathrm{H}$ de $60 \mathrm{MHz}$ das misturas iniciais e dos produtos obtidos, conforme abaixo descrito. Foram utilizados os espectros de $60 \mathrm{MHz}$, que são adquiridos sem solvente, porque nas análises de $600 \mathrm{MHz}$ observou-se a troca dos hidrogênios dos grupos $\mathrm{HC}=\mathrm{N}$ com o deutério do solvente $\left(\mathrm{CDCl}_{3}\right)$ (seção 4.2.9).

\subsubsection{Determinação da formação de aldeídos}

A conversão das ligações duplas e a seletividade da reação para os produtos desejados foram determinadas por $\mathrm{RMN}{ }^{1} \mathrm{H}$, baseado em um método descrito na literatura para acompanhar a reação de hidroformilação de ésteres etílicos de ácidos graxos. ${ }^{69}$

O primeiro passo para todos os cálculos é a determinação do número de ligações duplas do EMAG (número de ligações duplas, NLD, Equação 1), que é calculado pela divisão de metade da área do pico da região entre 5 e 5,5 ppm (pico B na Figura 19 (a)), 
atribuído aos hidrogênios olefínicos, por $1 / 3$ da área do pico em 3,6 ppm (pico A na Figura 19 (b)), atribuído aos três hidrogênios do grupo metóxido, os quais são usados como padrão interno.

$$
N L D=\frac{B / 2}{A / 3}
$$

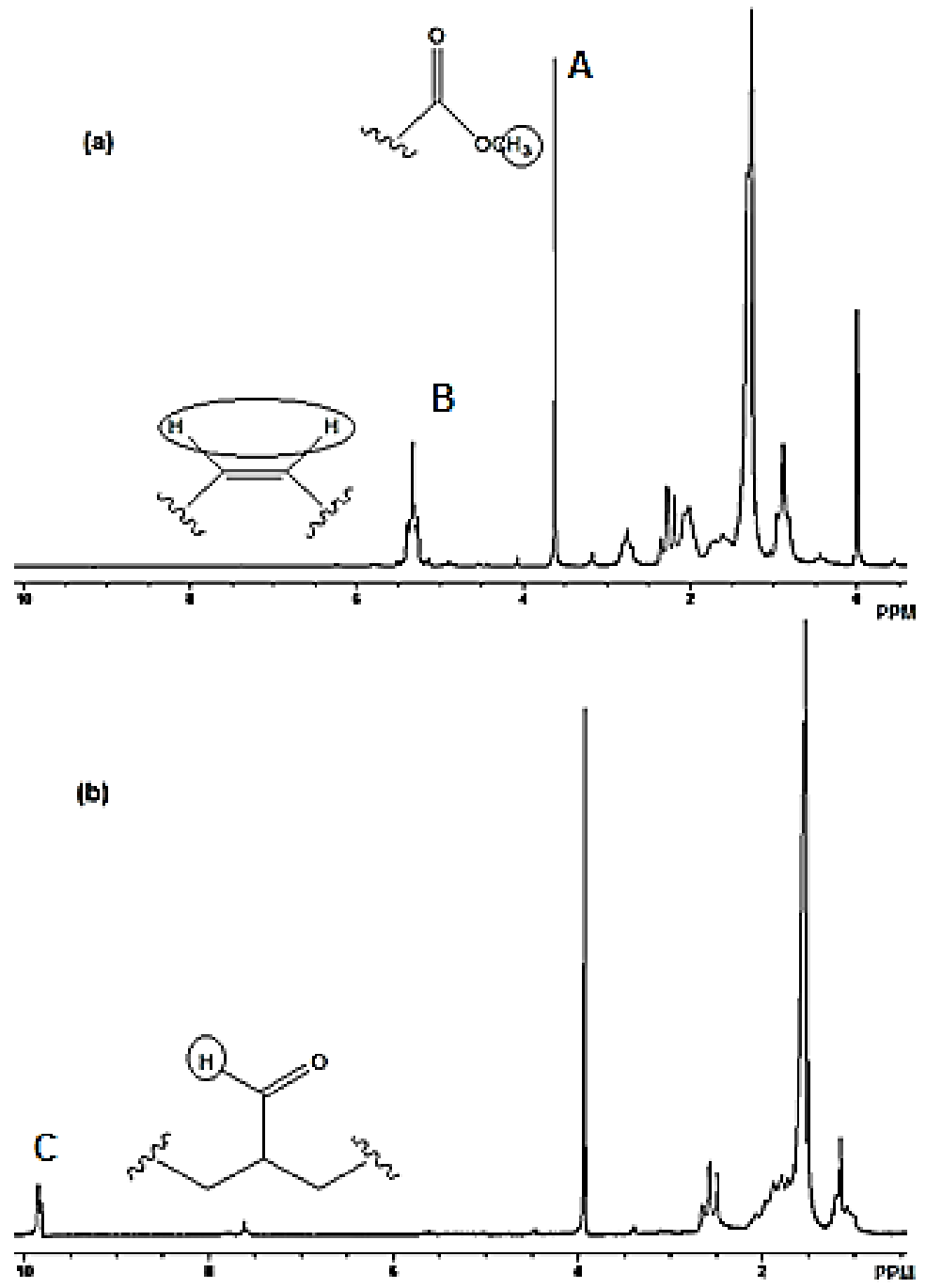

Figura 19. Principais atribuições nos espectros de $\mathrm{RMN}{ }^{1} \mathrm{H}$ para a reação de hidroformilação de EMAG (a) e seu produto de hidroformilação (b).

A quantidade de ligações duplas consumidas é determinada por meio da diferença entre a quantidade inicial e a quantidade final de ligações duplas $\left(\mathrm{NLD}_{\mathrm{i}}-\right.$ $\mathrm{NLD}_{\mathrm{f}}$, respectivamente) de acordo com a Equação 2. Em seguida, o número de hidrogênios de aldeído (NHA) é obtido a partir da divisão da área do pico do hidrogênio 
do aldeído em 9-9,5 ppm (C), pela terça parte da área do pico dos hidrogênios do grupo metóxido (Equação 3). A conversão, seletividade para aldeídos e rendimento são dados pelas equações 4 a 6 , respectivamente.

$$
\begin{gathered}
\Delta \mathrm{NLD}=\mathrm{NLD}_{\mathrm{i}}-\mathrm{NLD}_{\mathrm{f}} \\
\mathrm{NHA}=\frac{C}{\mathrm{~A} / 3} \\
\text { Conversão }=\left(\Delta \mathrm{NLD} / \mathrm{NLD}_{\mathrm{i}}\right) * 100 \\
\text { Seletividade (aldeído })=(\mathrm{NHA} / \Delta \mathrm{NLD}) * 100 \\
\text { Rendimento }=\text { conversão } * \text { seletividade }
\end{gathered}
$$$$
\text { (Equação 5) }
$$

(Equação 4)

(Equação 6)

\subsubsection{Reações de hidroiminometilação utilizando $n$-butilamina}

Conforme será discutido na seção 4.3, as rações de hidroformilação em presença de $n$-butilamina não ocasionaram considerável formação de aminas, mas apenas de iminas, ou seja, não houve a redução considerável destas. Por isso, as reações foram denominadas de hidroiminometilação em vez de hidroaminometilação e a seletividade e rendimento foram calculados para a formação de imina.

Por sua vez, o número de hidrogênios do grupo imina foi obtido por meio da divisão da área do pico em 7,4 ppm (pico D na Figura 20) pela terça parte da área do pico do grupo $\mathrm{CH}_{3}$ do grupo metóxi, de acordo com a Equação 3. Assim, a conversão, a seletividade e o rendimento para a formação de imina são dados pelas equações 4 a 6 , respectivamente. 


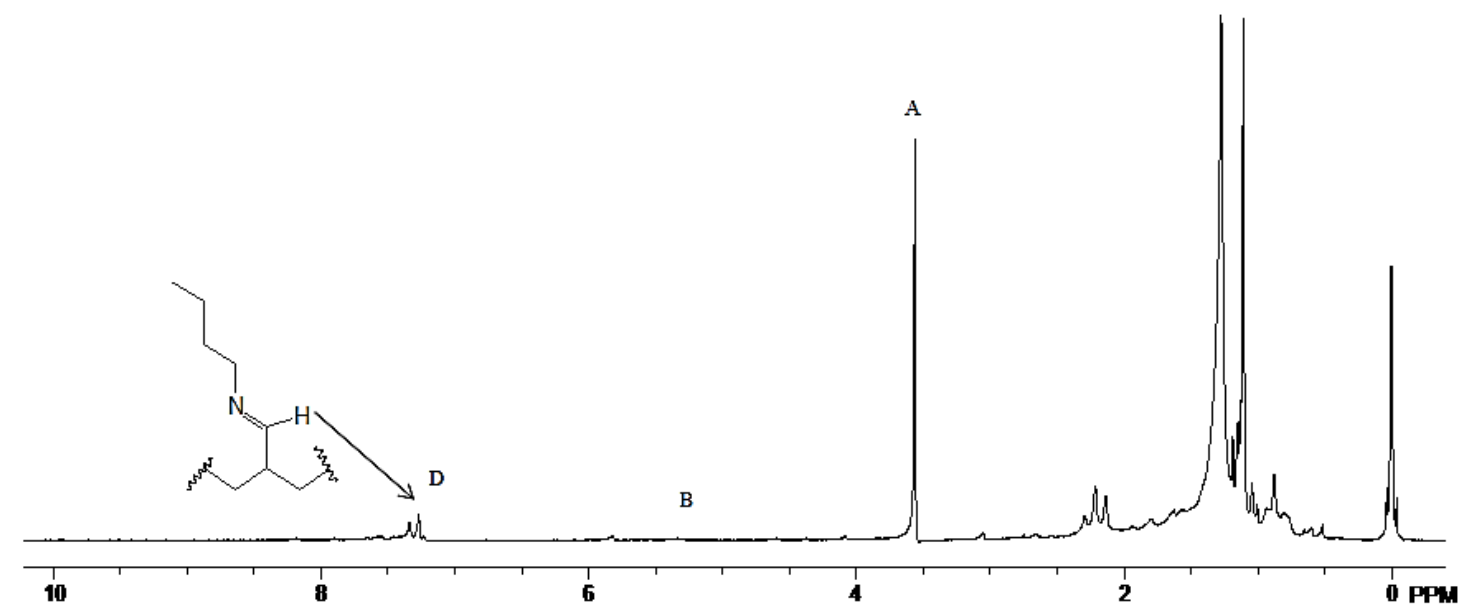

Figura 20. Principais atribuições nos espectros de $\mathrm{RMN}{ }^{1} \mathrm{H}$ para a reação de hidroformilação de EMAG na presença de $n$-butilamina.$$
\mathrm{NHIM}=\frac{D}{\mathrm{~A} / 3}
$$$$
\text { Conversão }=\left(\Delta \mathrm{NLD} / \mathrm{NLD}_{\mathrm{i}}\right) * 100
$$$$
\text { Seletividade }(\text { imina })=[\mathrm{NHIM} /(\Delta \mathrm{NLD}] * 100
$$$$
\text { Rendimento }=\text { conversão } * \text { seletividade }
$$$$
\text { (Equação 8) }
$$$$
\text { (Equação 9) }
$$

(Equação 10)

\title{
3.7. Testes de atividade biológica
}

\subsubsection{Teste de difusão em ágar}

O teste de difusão em ágar consiste em depositar a amostra a ser testada em um orifício feito em uma placa de Petri contendo um meio de cultura. Durante a incubação, a amostra difunde-se a partir dos orifícios para o meio de cultura. Após a incubação, o diâmetro da zona inibida (onde não houve crescimento de microrganismos) é medido. As colônias que cresceram na zona de inibição foram consideradas resistentes.

Os diâmetros das zonas de inibição foram medidos após 48 h de incubação a 32$37{ }^{\circ} \mathrm{C}$ usando um projetor ótico, uma régua ou um paquímetro. Os testes foram realizados em triplicata utilizando o meio de cultura ágar dextrose Sabouraud e ágar 
nutriente. Para este teste foram utilizadas cepas de bactérias e fungos padronizadas ATCC (American TypeCultureCollection). Microrganismos comuns do meio ambiente e que já foram isolados em combustíveis como diesel e biodiesel foram testados (ex: fungos C. krusei, C. parapsilosis, C. albicans, A. niger, A. fumigatusandS. cerevisae, e bactérias E. coli, B. subtillisandS. aureus). ${ }^{86}$

\subsubsection{Testes microbiológicos de suscetibilidade}

A suscetibilidade microbiana a amostras de biodiesel modificado e a blendas de biodiesel modificado/diesel foi determinada de acordo com o teste de microdiluição em caldo padronizado pelo CLSI (Clinical and Laboratory Standards Institute). As concentrações das amostras testadas variaram de $1 \mathrm{a} 512 \mu \mathrm{g} \mathrm{mL} \mathrm{m}^{-1}$. Devido à viscosidade relativamente alta das blendas de biodiesel/diesel, elas foram previamente dissolvidas em dimetilsulfóxido. Os microrganismos estudados foram os mesmos empregados no teste de difusão em ágar.

O meio de cultura usado foi o RPMI 1640 com L-glutaminas em bicarbonato de sódio, tamponado com $0,165 \mathrm{~mol} / \mathrm{L}$ de tampão MOPS (ácido morfolinopropanosulfônico) para $\mathrm{pH}$ 7,0 e esterilizado. O inóculo foi preparado a partir de colônias de leveduras cultivadas em ágar dextrose Sabouraud por 48 h a $35^{\circ} \mathrm{C}$. Uma suspensão foi preparada em solução aquosa de $\mathrm{NaCl}$ a $0,85 \%$, esterilizada, e a densidade celular medida por espectrofotometria para uma transmitância de $85 \%$ no comprimento de onda de $530 \mathrm{~nm}$. Esta suspensão foi posteriormente diluída a 1:100 e em seguida a 1:20 em meio de cultura RPMI1640, de modo a alcançar uma concentração final do inóculo de 0,5 a 2,5 x $10^{3}$ células $/ \mathrm{mL}$.

Para fungos filamentosos, o inóculo foi preparado a partir do micélio oriundo de culturas cultivadas em ágar batata dextrose por cinco dias a $35^{\circ} \mathrm{C}$. Foi preparada uma suspensão com os esporos dos fungos filamentosos com $\mathrm{NaCl}$ 0,85\% esterilizado e também se mediu a densidade celular em espectrofotometria para uma transmitância de $85 \%$ em comprimento de onda de $530 \mathrm{~nm}$. Essa suspensão foi então diluída em meio RPMI 1640 na proporção 1:5, obtendo-se 0,4 a 5,0 x 10 $0^{4} \mathrm{UFC} / \mathrm{mL}$ (UFC: unidades formadoras de colônia). O inóculo bacteriano foi preparado a partir de colônias de bactérias cultivadas em ágar nutritivo por $24 \mathrm{~h}$ a $35^{\circ} \mathrm{C}$. Depois de incubadas a $35{ }^{\circ} \mathrm{C}$ por $24 \mathrm{~h}$ horas, selecionaram-se colônias bem isoladas com uma alça bacteriológica e transferiu-se para um tubo de solução salina a $0,85 \%$. A suspensão bacteriana foi então 
comparada com o padrão 0,5 da escala McFarland. $\mathrm{O}$ tubo foi agitado imediatamente antes do uso.

Foram adicionados $100 \mu \mathrm{L}$ do inóculo em cada poço contendo as amostras já diluídas na placa. As placas foram incubadas a $35{ }^{\circ} \mathrm{C}$ por $48 \mathrm{~h}$ para bactérias, até $72 \mathrm{~h}$ para leveduras e até cinco dias para fungos filamentosos. A leitura foi realizada pela visualização de crescimento da levedura através da turvação no meio de cultura.

Todos os testes foram realizados em triplicata. A concentração mínima suficiente para evitar o crescimento microbiano representou a concentração inibitória mímina (CIM). Quando uma CIM observada é menor do que $256 \mu \mathrm{gmL}^{-1}$, os microrganismos são considerados suscetíveis à amostra em estudo.

\subsubsection{Teste de inibição de crescimento dos microrganismos com pesagem da biomassa fúngica}

Um Erlenmeyer contendo a amostra esterilizada e outro Erlenmeyer contendo biodiesel puro foram incubados em estufa. Os conteúdos destes Erlenmeyers foram

então inoculados com o fungo A. fumigatus com concentração de $10^{6} \mathrm{UFC} \mathrm{mL}^{-1}$, que foi escolhido porque apresentou os melhores resultados para os testes anteriores (Seção 4.3.1). O crescimento microbiano foi acompanhado por meio da retirada de alíquotas em 7, 14 e 28 dias de incubação. A massa fúngica seca de cada alíquota foi pesada para avaliar o crescimento do microrganismo. 
CAPítulo 4

RESULTADOS E DISCUSSÃo 


\subsection{Conversão do óleo de soja em EMAG}

Os teores de cada componente do biodiesel obtido após a conversão máxima (triacilglicerídeo - TAG, diacilglicerídeo - DAG, biodiesel - EMAG, monoacilglicerídeo - MAG e ácido graxo - AG) foram determinados por meio das razões entre as áreas de cada pico pela soma total das áreas dos cromatogramas obtidos por CLAE. Os resultados estão apresentados na Tabela 1.

Tabela 1. Composição do biodiesel obtido por meio da transesterificação de óleo de soja.

\begin{tabular}{ccccc}
\hline Componente & AG/MAG & DAG & TAG & EMAG \\
\hline$(\%)$ & $1 \%$ & $0 \%$ & $0 \%$ & $99 \%$ \\
\hline
\end{tabular}

\subsection{Reações de hidroformilação em presença e ausência de $\boldsymbol{n}$-butilamina}

O enfoque desta seção é apresentar os resultados e discussões referentes às reações de hidroformilação realizadas na presença de $n$-butilamina para a obtenção de produtos nitrogenados. Os valores de conversão, seletividade e rendimento das reações são apresentados na Tabela 2, na próxima seção. As reações foram realizadas em presença ou não de um excesso do ligante $\mathrm{PPh}_{3}, \mathrm{com}$ a finalidade de se avaliar o efeito de sua presença. Via de regra, utilizou-se um sistema bifásico com o líquido iônico $\mathrm{BMI} \mathrm{PF}_{6}$. Entretanto, para efeito de comparação, algumas reações foram realizadas também na ausência do líquido iônico (em meio homogêneo).

\subsubsection{Sistema de nomenclaturas}

Para facilitar a discussão dos resultados, foi criado um sistema de nomenclatura que descreve as reações/produtos de acordo com as condições reacionais utilizadas. Este sistema consiste de quatro campos. O campo 1 diferencia se a reação foi realizada em sistema catalítico homogêneo ou bifásico. Sem a presença de líquido iônico, utilizou-se a sigla "Ho"; quando o sistema usado foi o bifásico, a sigla utilizada foi "LI", remetendo ao uso do líquido iônico. Campo 2: diz respeito à quantidade do ligante $\mathrm{PPh}_{3}$ adicionado ao meio reacional, empregando-se a sigla " 0 " quando não houve adição e "P" quando houve (excesso de 10 vezes relativo à quantidade molar de ródio). Campo 
3: representa o tempo de reação, de forma que " 6 " representa uma reação de $6 \mathrm{~h}$, enquanto "24" representa uma reação de 24 h. Campo 4: indica a razão molar entre o número de ligações duplas e a quantidade de ródio (NLD/Rh); assim, "750" e "2000" representam as reações realizadas com um excesso molar de ligações duplas/Rh igual a 750 e 2000, respectivamente. Dessa maneira, por exemplo, LI.0.24.750 corresponde à reação (assim como a seu produto) realizada na presença de $n$-butilamina, usando o sistema reacional bifásico contendo líquido iônico, sem a adição de excesso de $\mathrm{PPh}_{3}$, por $24 \mathrm{~h}$, com uma razão molar NLD/Rh $=750$.

Ainda com relação à nomenclatura, o produto LI.P.24.750, que apresentou elevado rendimento para formação de imina, será denominado, doravante, EMAGHIM (ésteres metílicos de ácidos graxos hidroiminometilados). Alguns dos prováveis produtos estão mostrados na Figura 21.

Tabela 2. Conversão, seletividade e rendimento para as reações de hidroformilação realizadas em presença de $n$-butilamina.

\begin{tabular}{|c|c|c|c|c|c|c|c|}
\hline \multicolumn{4}{|c|}{ Condições Reacionais } & \multirow{2}{*}{$\begin{array}{l}\text { Reação/ } \\
\text { Produto }\end{array}$} & \multirow{2}{*}{$\begin{array}{l}\text { Conver- } \\
\text { são (\%) }\end{array}$} & \multirow{2}{*}{$\begin{array}{l}{ }^{\mathrm{e}} \text { Seletivi- } \\
\text { dade (\%) }\end{array}$} & \multirow{2}{*}{$\begin{array}{c}{ }^{\mathrm{e}} \text { Rendimento } \\
(\%)\end{array}$} \\
\hline${ }^{\mathrm{a}} \mathrm{LI}$ & ${ }^{6} \mathrm{PPh}_{3} / \mathrm{Rh}$ & $c_{t}(h)$ & ${ }^{\mathrm{d}} \mathrm{NLD} / \mathrm{Rh}$ & & & & \\
\hline \multirow{2}{*}{ Não } & 0 & 6 & 750 & Ho.0.6.750 & 77 & 43 & 33 \\
\hline & 10 & 6 & 750 & Ho.P.6.750 & 79 & 77 & 60 \\
\hline \multirow{10}{*}{ Sim } & \multirow{2}{*}{0} & \multirow{2}{*}{6} & 750 & LI.0.6.750 & 65 & 76 & 49 \\
\hline & & & 2000 & LI.0.6.2000 & 45 & 64 & 28 \\
\hline & \multirow{2}{*}{10} & \multirow{2}{*}{6} & 750 & LI.P.6.750 & 84 & 98 & 82 \\
\hline & & & 2000 & $\begin{array}{l}\text { LI.P.6.2000 } \\
\end{array}$ & 55 & 84 & 46 \\
\hline & \multirow{2}{*}{0} & \multirow{2}{*}{24} & 750 & LI.0.24.750 & 90 & 68 & 61 \\
\hline & & & 2000 & LI.0.24.2000 & 56 & 66 & 37 \\
\hline & \multirow{2}{*}{10} & \multirow{2}{*}{24} & 750 & $\begin{array}{c}\text { LI.P.24.750 } \\
\text { (EMAGHIM) }\end{array}$ & 94 & 80 & 75 \\
\hline & & & 2000 & LI.P.24.2000 & 72 & 60 & 43 \\
\hline & \multirow{2}{*}{10} & \multirow{2}{*}{24} & 750 & LI.P. 24.750 & 77 & 43 & 46 \\
\hline & & & 2000 & LI.P.24.2000 & 79 & 77 & 61 \\
\hline
\end{tabular}

${ }^{\mathrm{a}} \mathrm{BMI} . \mathrm{PF}_{6}$

${ }^{\mathrm{b}}$ razões molares

'tempo de reação

${ }^{d}$ razão molar entre o número de duplas ligações e a quantidade de ródio

epara imina 


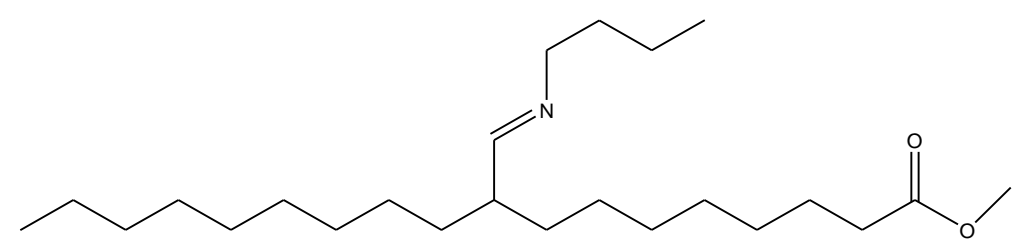

(a)

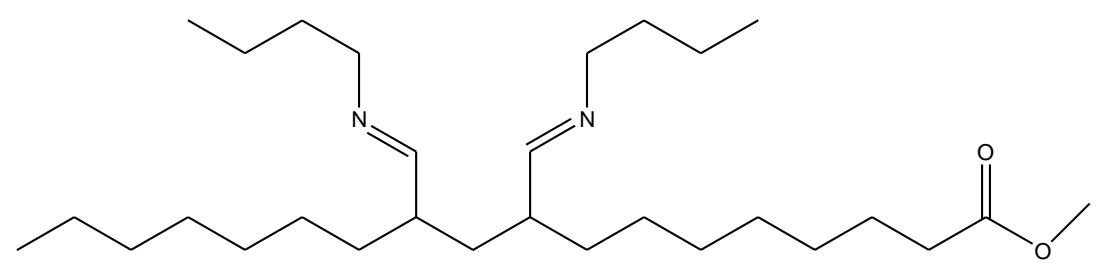

(b)

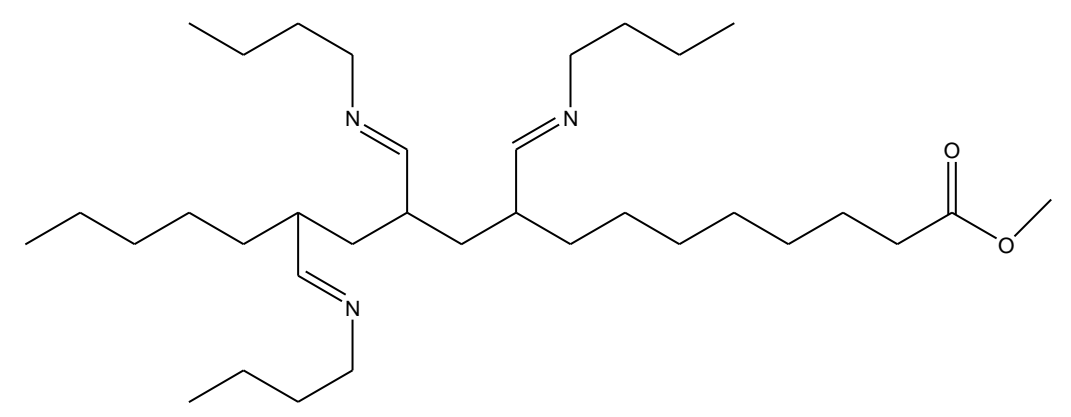

(c)

Figura 21. Prováveis produtos formados a partir da hidroiminometilação de EMAG.

\subsubsection{Formação de aldeído vs. imina vs. amina}

Conforme reportado na seção 2.3 , reações de hidroformilação conduzidas na presença de aminas primárias geram iminas como resultado da condensação do aldeído formado na etapa de hidroformilação com a amina adicionada. De fato, para todas as reações realizadas em presença da $n$-butilamina e catalisadas por complexo de $\mathrm{Rh}$, nenhuma evidência da presença de aldeído no produto pôde ser detectada. Por exemplo, a banda característica de absorção na região do infravermelho deste grupo (estiramento C-H em $2710 \mathrm{~cm}^{-1}$ ), que pode ser verificada no espectro de um produto típico de hidroformilação, não é observada no espectro do produto EMAGHIM (Figura 22). Além disso, não é possível observar a presença do sinal do hidrogênio do grupo aldeído (em 9,0 ppm) nos espectros de RMN ${ }^{1} \mathrm{H}$ do produto EMAGHIM (Figura 23). 
Outro aspecto dos espectros de $\mathrm{RMN}{ }^{1} \mathrm{H}$ que evidencia a condensação da $n$ butilamina com a carbonila do produto de hidroformilação é o aparecimento do pico em 1,16 ppm, que corresponde aos hidrogênios do grupo $\mathrm{CH}_{2}$ ligado ao nitrogênio. Nos espectros de $60 \mathrm{MHz}$, este pico encontra-se, via de regra, parcialmente sobreposto com os picos dos hidrogênios do grupo $\mathrm{CH}_{3}$ e $\mathrm{CH}_{2}$ em posições típicas para hidrocarbonetos (abaixo de 1,0 ppm e próximo a 1,25 ppm, respectivamente), o que compromete sua integração.

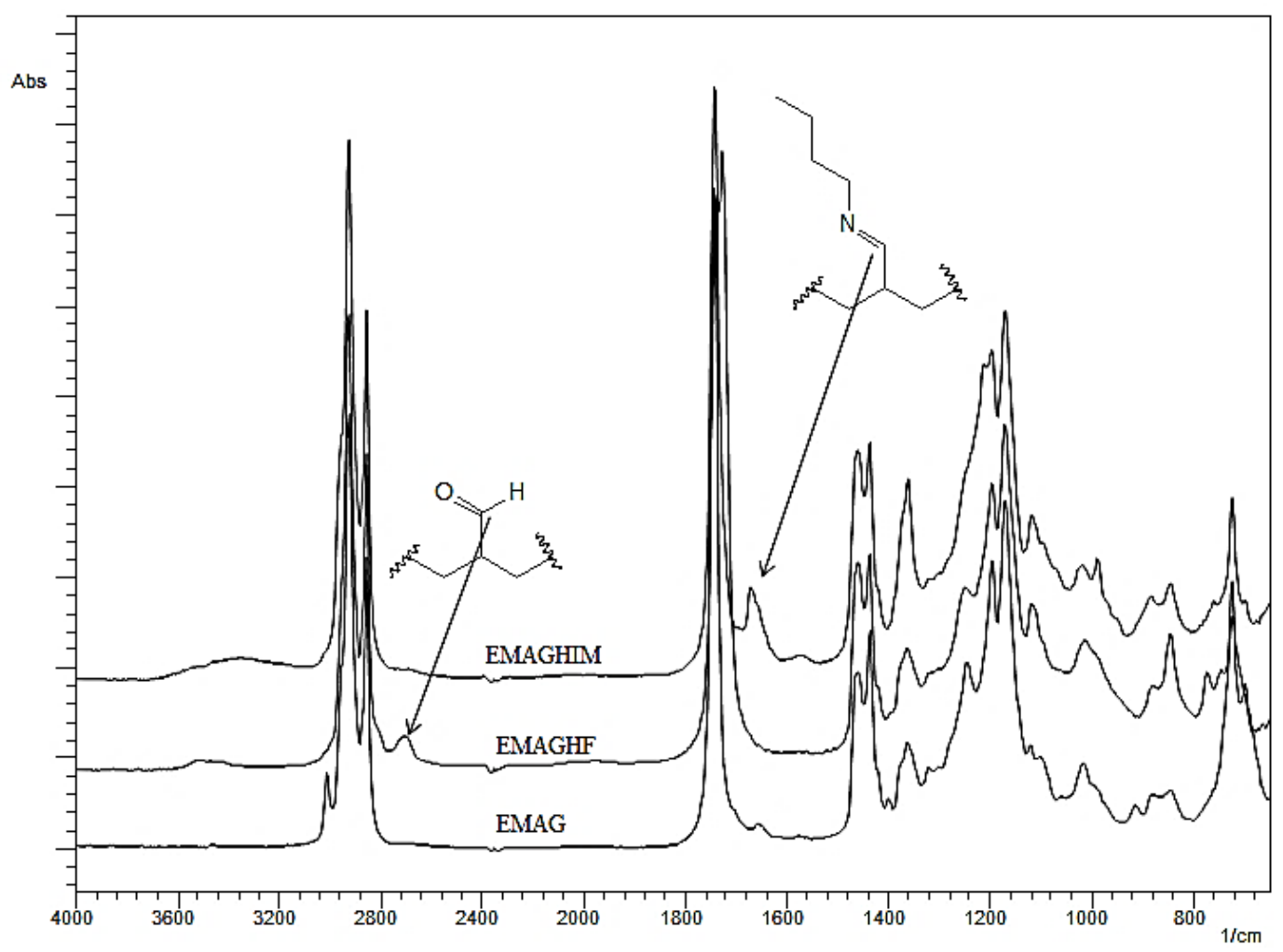

Figura 22. Espectros de infravermelho do (a) EMAG de soja e dos produtos de sua reação de hidroformilação em (b) ausência (EMAGHF) e (c) na presença de $n$ butilamina (EMAGHIM).

Ainda segundo a seção 2.3, usualmente as iminas são hidrogenadas nas condições empregadas para hidroformilação, formando as respectivas aminas. Contudo, os espectros de infravermelho e de $\mathrm{RMN}{ }^{1} \mathrm{H}$ apontam para uma pronunciada presença de imina nos produtos obtidos a partir das reações de hidroformilação em presença de $n$ butilamina, ao passo que as evidências da presença de aminas foram bastante tênues ou inexistentes. 


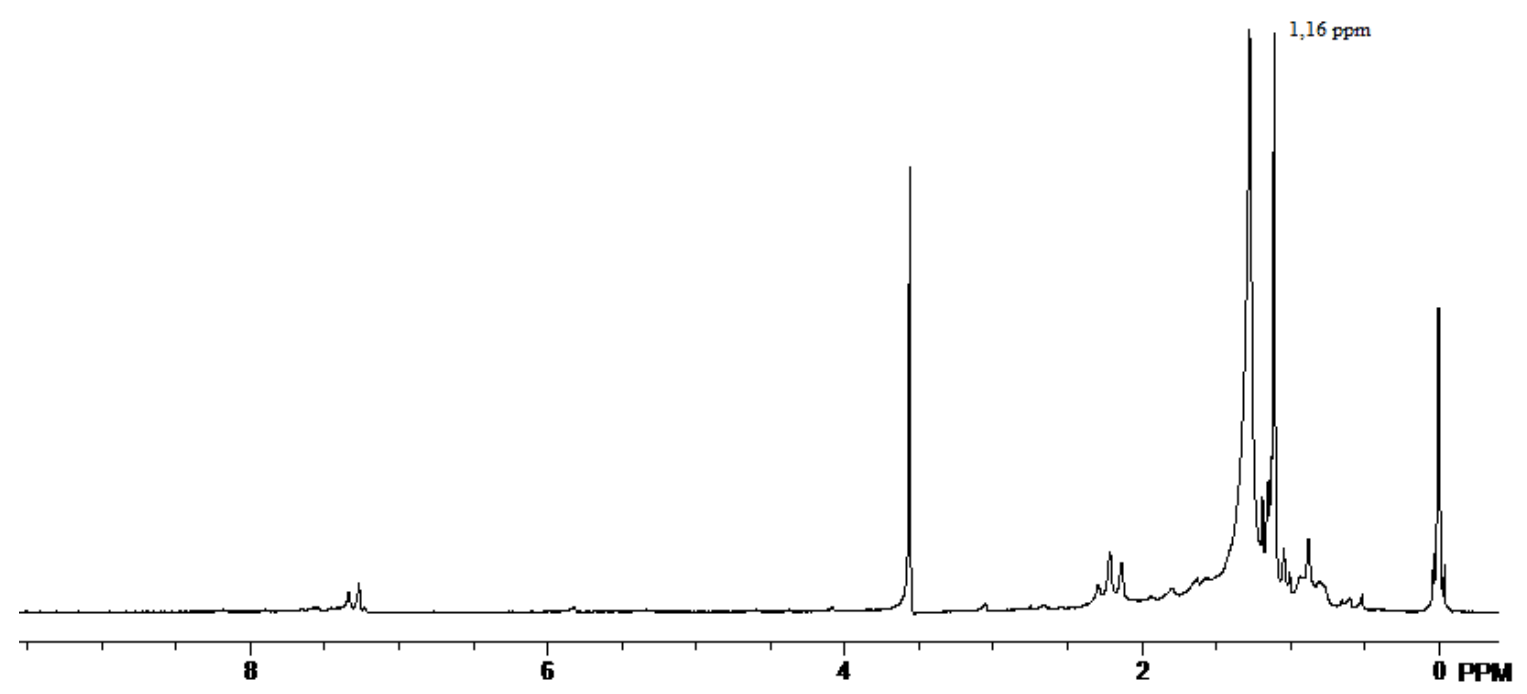

Figura 23. Espectro de RMN ${ }^{1} \mathrm{H}$ do EMAGHIM mostrando sobreposição dos picos do radical $n$-butila com picos de $\mathrm{CH}_{2}$ e $\mathrm{CH}_{3}$ da região graxa das cadeias.

Nos espectros de infravermelho, o desaparecimento da banda de estiramento C$\mathrm{H}$ em carbono $\mathrm{sp}^{2}$ (indicativo da presença de ligações $\mathrm{C}=\mathrm{C}$ no EMAG) foi acompanhado pelo surgimento de uma banda relativa ao estiramento $\mathrm{C}=\mathrm{N}$ em $1670 \mathrm{~cm}^{-1}$ (Figura 22c), a qual é atribuída ao grupo imina. Já nos espectros de $\mathrm{RMN}{ }^{1} \mathrm{H}$, conforme já discutido na seção 3.6.2, ocorre o surgimento de um pico característico do hidrogênio ligado ao carbono $\mathrm{sp}^{2}$ do grupo imina, em 7,4 ppm (Figura 23).

Com relação à amina, nos espectros de $\mathrm{RMN}{ }^{1} \mathrm{H}$, a única evidência de sua presença em alguns dos produtos foi o aparecimento, nos espectros obtidos a $600 \mathrm{MHz}$, de um sinal de pouca intensidade e multiplicidade indefinida em 2,42 ppm, o qual foi atribuído, conforme detalhado na seção 4.2.9, aos hidrogênios-alfa pertencentes ao grupo - $\mathrm{CH}_{2} \mathrm{NHCH}_{2^{-}}$. Entretanto, conforme discutido na própria seção 4.2.9, há evidências irrefutáveis de que a integração desse sinal esteja subestimada, de forma que não foi possível determinar, por meio da metodologia aqui empregada, a seletividade para aminas.

Os resultados apresentados ao longo desta seção levam à conclusão de que a etapa de hidrogenação de iminas não ocorreu nas condições empregadas para a hidroformilação em presença de $n$-butilamina no presente trabalho. Assim, as seletividades para essas reações na Tabela 2 foram calculadas para imina. Ainda, as reações foram denominadas de hidroiminometilação em vez de hidroaminometilação. 


\subsubsection{Iminação vs aminação}

Briggs e colaboradores realizaram a hidroformilação do 1-penteno na presença de piperidina usando $\mathrm{Rh}(\mathrm{CO})_{2}$ (acac) como precursor catalítico, além de fosfito e bifosfito como ligantes auxiliares. Quando a reação foi realizada empregando-se quantidades equimolares de bifosfito e $\mathrm{Rh}$, o rendimento em amina foi baixo. Entretanto, se a razão molar bifosfito/Rh foi diminuída para menos de 1 , o rendimento em amina aumentou abruptamente. ${ }^{81}$

Os autores interpretaram esses resultados como um indicativo de que a hidrogenação da enamina intermediária é catalisada predominantemente por um complexo de $\mathrm{Rh}$ que não contém o ligante bifosfito (supostamente, $\mathrm{HRh}(\mathrm{CO})_{3}$ ). Dessa forma, se uma quantidade equimolar do ligante e de Rh é usada, a hidrogenação seria suprimida porque praticamente todo o Rh estaria coordenado ao ligante bidentado, o qual forma complexo muito estável. Por outro lado, usando-se um excesso de Rh, estarse-ia garantindo a existência de espécies contendo Rh não coordenado ao bifosfito em quantidade suficiente para promover a hidrogenação.

Por sua vez, dos Santos e colaboradores ${ }^{82}$ investigaram a hidroformilação de monoterpenos na presença de aminas usando $[\mathrm{Rh}(\operatorname{cod})(\mu-\mathrm{OMe})]_{2}$ como precursor catalítico. Eles verificaram que a adição de $\mathrm{PPh}_{3}$ ao sistema reacional previne a ocorrência de reações laterais mas, por outro lado, dificulta a hidrogenação das iminas/enaminas formadas como intermediários. Os autores interpretaram os resultados da seguinte maneira: quanto mais elevada a concentração de $\mathrm{PPh}_{3}$, mais alta a concentração de equilíbrio de espécies contendo $\mathrm{Rh}$ não coordenado à $\mathrm{PPh}_{3}$, as quais são menos ativas para reações de hidrogenação, tanto de olefinas quanto de iminas/enaminas.

Os resultados apresentados por Briggs et al. e por dos Santos et al. podem ser compreendidos à luz do trabalho de Clarke et al., ${ }^{83}$ que propuseram que ligantes doadores de elétrons (como são os casos do bifosfito e da $\mathrm{PPh}_{3}$ ) são menos ativos do que ligantes retiradores de elétrons (como é o caso do $\mathrm{CO}$ ) para reações de hidrogenação.

No que diz respeito aos resultados apresentados na Tabela 2, é necessário salientar que, ao contrário do que ocorreu nos trabalhos de Briggs e dos Santos, utilizou-se como precursor do catalisador um complexo que já continha $\mathrm{PPh}_{3}$ em proporção de 3:1 em relação ao Rh, o $\mathrm{HRhCO}\left(\mathrm{PPh}_{3}\right)_{3}$. Assim, mesmo sem a adição de 
$\mathrm{PPh}_{3}$, supõe-se que não houve considerável formação, no sistema reacional, de espécies contendo $\mathrm{Rh}$ não coordenado a $\mathrm{PPh}_{3}$, de forma que a reação de hidrogenação das iminas não foi favorecida.

Neste ponto, seria possível postular que a inexistência de espécies contendo Rh não coordenado $\mathrm{aPh}_{3}$ estaria diretamente relacionada à presença do líquido iônico, que estabiliza espécies contendo $\mathrm{PPh}_{3}$ coordenada ao Rh. Entretanto, é necessário destacar que a presença de aminas foi quase imperceptível mesmo nos produtos das reações realizadas na ausência de líquido iônico (reações Ho.0.6.750 e Ho.P.6.750), com o que se conclui não ser o líquido iônico o responsável por suprimir a hidrogenação das iminas.

\subsubsection{Reações em meio homogêneo}

A reação de hidroformilação em presença de $n$-butilamina realizada por $6 \mathrm{~h}$ em meio homogêneo, com um NDL/Rh $=750$, sem o emprego de um excesso de $\mathrm{PPh}_{3}$ (reação Ho.0.6.750), mostrou uma conversão de $77 \%$ e uma seletividade para imina de 43\%. Por sua vez, na presença de $\mathrm{PPh}_{3}$, a conversão foi semelhante (79\%), mas a seletividade subiu para $77 \%$. A explicação para isso é de que a presença do excesso da $\mathrm{PPh}_{3}$ favoreça, por deslocamento do equilíbrio, a formação de espécies contendo esse ligante coordenado ao $\mathrm{Rh}$, que são ativas para a hidroformilação, em detrimento a espécies que são ativas para reações de hidrogenação (ver discussão na seção 2.4). No presente caso, a hidrogenação poderia ser das ligações $\mathrm{C}=\mathrm{C}$ presentes no material de partida (reação paralela) ou da ligação $\mathrm{C}=\mathrm{N}$ da imina (reação consecutiva), sendo que ambas resultam em uma menor seletividade para imina.

\subsubsection{O emprego do sistema catalítico bifásico contendo BMI.PF 6}

A comparação das reações realizadas em condições idênticas, mas em meio homogêneo ou bifásico (Ho.0.6.750 e LI.0.6.750; Ho.10.6.750 e LI.10.6.750) mostra que a presença do líquido iônico propiciou pronunciado aumento de seletividade. Esse aumento ocorreu tanto para as reações em ausência de $\mathrm{PPh}_{3}$ como na presença de um excesso desse ligante (de 43 para $76 \%$ e de 77 para 98\%, respectivamente). Esses resultados são atribuídos ao "efeito do líquido iônico" (seção 2.2.3), o qual pode agir estabilizando o complexo catalítico em formas ativas para a hidroformilação (que 
contém a $\mathrm{PPh}_{3}$ coordenada ao Rh, conforme discutido na seção 2.4) e/ou estabilizando o complexo ativado e/ou intermediários das reações envolvidas na formação de imina.

No que diz respeito à conversão, a comparação das reações Ho.10.6.750 e LI.10.6.750 mostra que, na presença de um excesso de $\mathrm{PPh}_{3}$, o emprego do sistema bifásico gerou um aumento da conversão, de 79 para 84\%, o que está de acordo com o supracitado efeito do líquido iônico. Por outro lado, a comparação das reações Ho.0.6.750 e LI.0.6.750 demonstra que, na ausência do excesso de $\mathrm{PPh}_{3}$, o emprego do sistema bifásico resultou em uma diminuição da conversão, de 77 para 65\%. Os diferentes comportamentos verificados em presença e ausência da $\mathrm{PPh}_{3}$ sugerem que, no segundo caso, espécies catalíticas menos ativas para a hidroformilação do EMAG estejam sendo formadas.

Uma possibilidade é que a $n$-butilamina esteja reagindo com o cátion imidazólio para formar carbenos do tipo $N$-heterocíclicos que, por sua vez, poderiam complexar com o Rh. Conforme discutido na seção 2.2.4, esses carbenos podem atuar como ligantes doadores de elétrons, de maneira similar à $\mathrm{PPh}_{3}$; porém, a atividade dos complexos formados seria menor do que a verificada para os complexos com $\mathrm{PPh}_{3}$, o que justificaria a observada diminuição da conversão. Ainda, a formação dos complexos com os carbenos ajudaria a reduzir a ocorrência de espécies ativas para reações de hidrogenação (formadas por espécies receptoras de elétrons), de forma que a seletividade verificada foi elevada.

No caso das reações realizadas em presença de $\mathrm{PPh}_{3}$, o excesso deste ligante seria capaz de suprimir a formação dos complexos contendo os ligantes do tipo carbeno, de forma que a adição do líquido iônico não provocou diminuição da conversão.

\subsubsection{O efeito da proporção do catalisador}

A comparação entre as reações realizadas por $6 \mathrm{~h}$ em condições idênticas, mas com uma proporção diferente entre EMAG/Rh (compare as reações LI.0.6.750 com LI.0.6.2000 e LI.10.6.750 com LI.10.6.2000) mostra que, como esperado, o uso de uma proporção menor de catalisador ocasionou uma redução da velocidade de conversão. Além disso, ocorreu, também, uma perda significativa de seletividade, que diminuiu de 76 para $64 \%$ e de 98 para $84 \%$ para as reações realizadas na ausência e presença de excesso de $\mathrm{PPh}_{3}$, respectivamente. Uma possível explicação para esta perda de seletividade é que, quanto menor a proporção de catalisador, maior é o número de ciclos 
aos quais ele é submetido. Isto faz com que o catalisador esteja mais sujeito a ser convertido em outras formas catalíticas ativas para reações paralelas e/ou consecutivas.

\subsubsection{O efeito do tempo de reação}

A comparação das reações realizadas em condições idênticas, por diferentes períodos de tempo e empregando uma proporção mais elevada do catalisador (NLD/Rh =750) demonstra que, conforme seria de se esperar, maiores tempos de reação levam a aumentos da conversão (compare as reações: IL.0.6.750 com IL.0.24.750 e IL.10.6.750 com IL.10.24.750). Além disso, houve também considerável perda de seletividade para imina: de 76 para $68 \%$ e de 98 para $80 \%$ para as reações realizadas em ausência e presença de um excesso de $\mathrm{PPh}_{3}$, respectivamente.

A perda de seletividade com o passar do tempo de reação leva à conclusão de que reações consecutivas estão consumindo a imina formada, sendo válido destacar que efeito semelhante foi observado nas reações de simples hidroformilação (em ausência de amina), conforme reportado em trabalho anteriormente publicado. ${ }^{14}$

Uma possibilidade para essas reações consecutivas é de que as espécies catalíticas contendo ligantes retiradores de elétrons, ativas para hidrogenação, passem a agir sobre as iminas formadas no caso das reações de hidroformilação em presença da $n$ butilamina, ou sobre os aldeídos formados no caso das reações de hidroformilação em ausência de amina. Entretanto, essa hipótese ainda não pôde ser confirmada porque, conforme já citado na seção 4.2.2 e será discutido mais detalhadamente na seção 4.2.10, houve grande dificuldade em detectar a formação das aminas por meio das análises de $\mathrm{RMN}{ }^{1} \mathrm{H}$ e infravermelho realizadas.

Não se pode descartar a possibilidade de que a ocorrência das reações consecutivas esteja relacionada à formação de nanopartículas de ródio, as quais foram detectadas nos produtos das reações realizadas por maiores períodos de tempo, especialmente quando não foi empregado um excesso de $\mathrm{PPh}_{3}$. A presença das nanopartículas com cerca de $10 \mathrm{~nm}$ de diâmetro médio foi evidenciada por meio do escurecimento do líquido iônico e por análises de microscopia de força atômica (Figura 23).

As reações consecutivas poderiam envolver desde a simples hidrogenação da imina formada, até a quebra da ligação alfa do carbono da imina. Esta segunda 
possibilidade é levantada com base em um paralelo com a reação de decarbonilação de aldeídos reportada na literatura. ${ }^{84}$

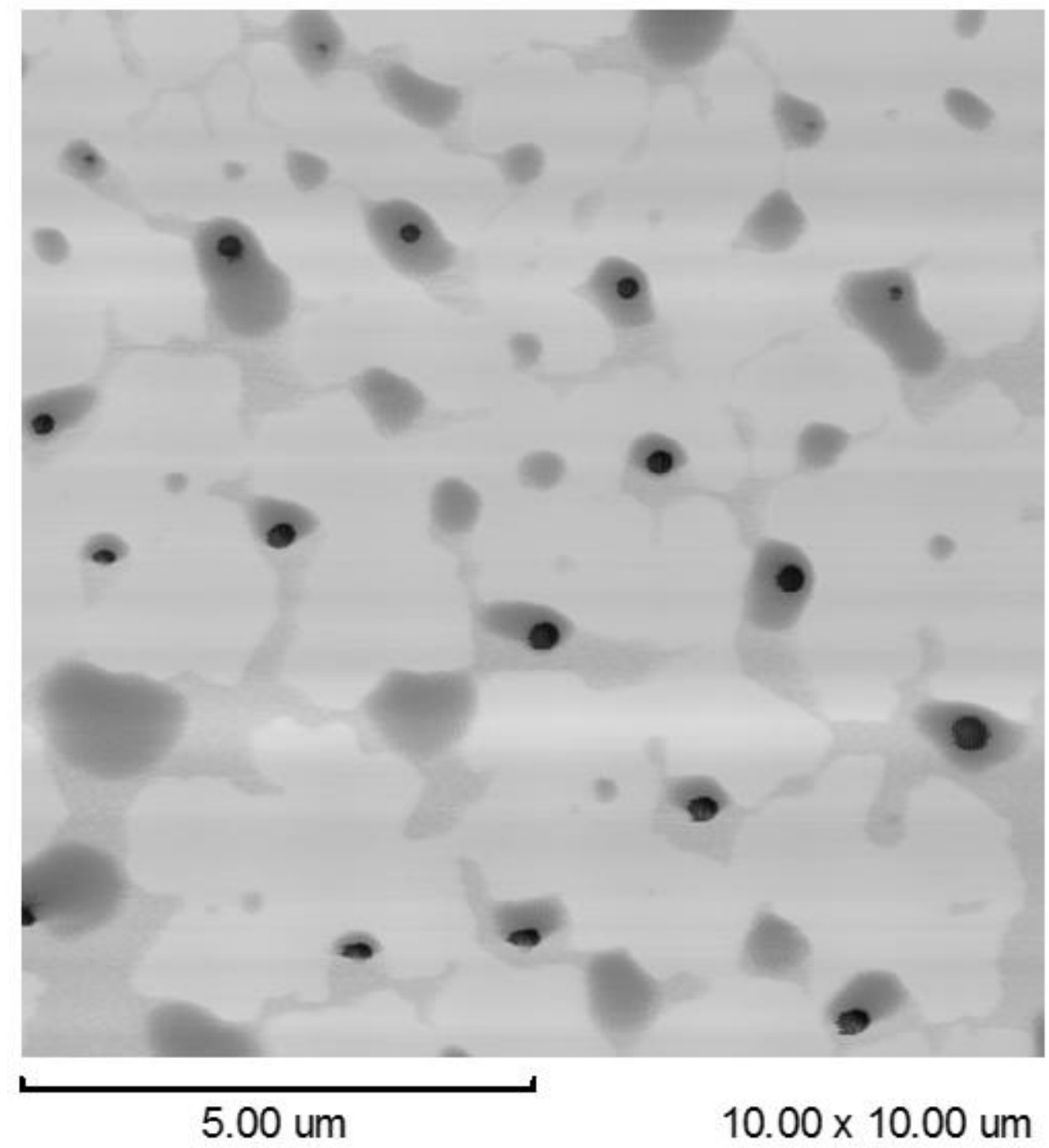

Figura 24. Microscopia de força atômica do produto LI.0.24.750 indicando a formação de nanopartículas de ródio no meio reacional.

\subsubsection{Reciclo do sistema catalítico}

Uma das características mais importantes dos sistemas catalíticos bifásicos é a capacidade de reutilização da fase contendo o catalisador para seguidas reações. Para a reação de hidroformilação em presença da $n$-butilamina, esse reciclo foi realizado pela 
simples retirada da fase orgânica do meio reacional após o término da reação e adição de nova carga de reagentes.

Foi observado que, utilizando condições reacionais semelhantes às empregadas para a formação do produto LI.10.24.750, o sistema não apresentou atividade significativa para uma segunda reação. Uma análise por ICP/AES mostrou que uma quantidade significativa do catalisador (aproximadamente $75 \%$ ) foi lixiviada para a fase orgânica. Este comportamento pode ser atribuído ao caráter eletricamente neutro do complexo utilizado, além da alta afinidade do ligante $\mathrm{PPh}_{3}$ com a fase orgânica.

Uma tentativa de evitar este lixiviamento foi realizada substituindo-se o ligante $\mathrm{PPh}_{3}$ pelo ligante trifenilfosfina trissulfonada (Figura 25). Com o emprego deste ligante, em que se fazem presentes espécies iônicas, observou-se que a perda de atividade do sistema durante ciclos sucessivos foi bem menor, sendo verificados rendimentos de $42 \mathrm{e}$ $18 \%$ para o segundo e o terceiro ciclos, respectivamente. Estes rendimentos foram possíveis graças a uma melhor fixação do catalisador na fase iônica. Entretanto, eles ainda se encontram bastante aquém do desejável, sendo este um ponto que precisa ser mais bem investigado no intuito de se obter melhores resultados.

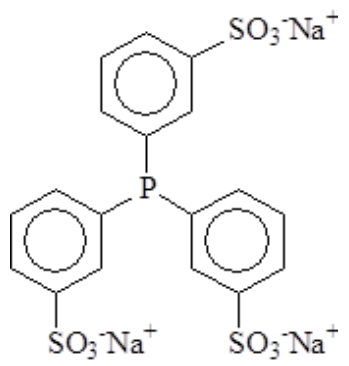

Figura 25. Ligante trifenilfosfina trissulfonada.

\subsubsection{Tentativa de hidrogenação da imina utilizando condições redutivas mais severas}

Uma tentativa para hidrogenação dos grupos imina formados durante a reação de hidroiminometilação foi realizada da seguinte forma: após a reação de hidroiminometilação, o reator foi despressurizado e o excesso de amina que não reagiu foi retirado do reator por alto vácuo. Em seguida, uma alta pressão de $\mathrm{H}_{2}$ (80 bar) foi aplicada no reator, que foi novamente selado. A mistura reagiu então por $24 \mathrm{~h}$. 
A análise do produto por infravermelho não indicou a conversão das moléculas contendo o grupo imina, pois a banda correspondente a ligação $\mathrm{C}=\mathrm{N}$ característica de imina (1670 $\left.\mathrm{cm}^{-1}\right)$ não sofreu aparente mudança de intensidade (Figura 26). Além disso, não foram observadas alterações consideráveis nos valores de conversão ou seletividade para o produto, indicando a presença de espécies pouco ativas para a hidrogenação no meio reacional.

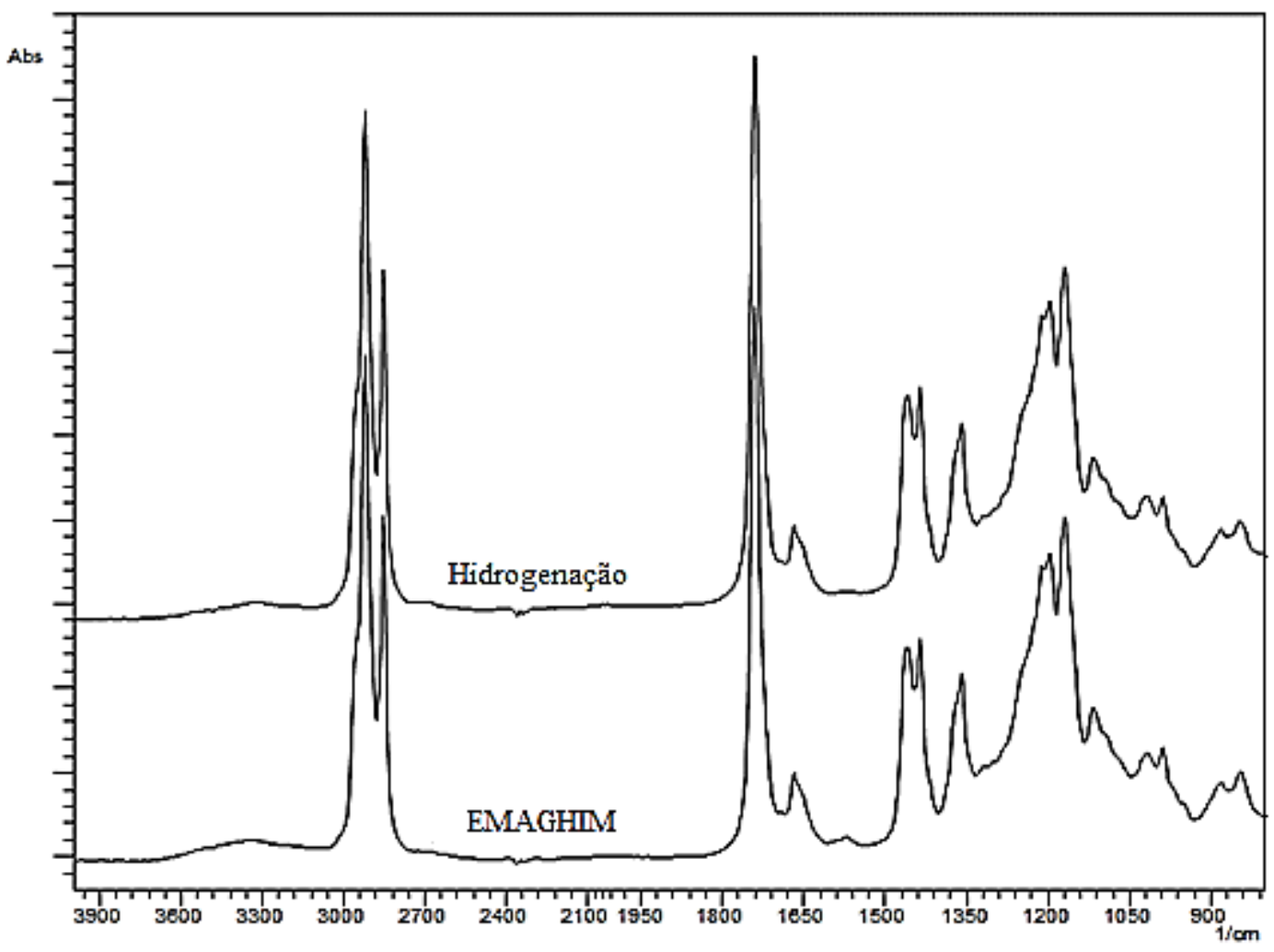

Figura 26. Espectros de infravermelho do EMAGHIM e do produto obtido após tentativa de hidrogenação.

\subsubsection{Redução dos produtos de hidroiminometilação com $P d / C$}

Após os insucessos anteriores nas tentativas de hidrogenação dos compostos contendo imina, o produto LI.0.24.750 foi submetido a uma reação subsequente em presença de $\mathrm{H}_{2}(\mathrm{~g})$ e paládio suportado em carbono ativado ( $\mathrm{Pd} / \mathrm{C} 5 \%$ em massa), reconhecidamente um poderoso catalisador para hidrogenação.

Os espectros de infravermelho demonstram que a reação com o $\mathrm{Pd} / \mathrm{C}$ levou ao desaparecimento da banda relativa ao estiramento $\mathrm{C}=\mathrm{N}$ em $1670 \mathrm{~cm}^{-1}$, característica do grupo imina (Figura 27). Além disso, o espectro de RMN ${ }^{1} \mathrm{H} 60 \mathrm{MHz}$ demonstrou que 
houve o desaparecimento do pico relativo ao hidrogênio do grupo $\mathrm{HC}=\mathrm{N}$. Estas observações indicam que houve a conversão das moléculas de imina.

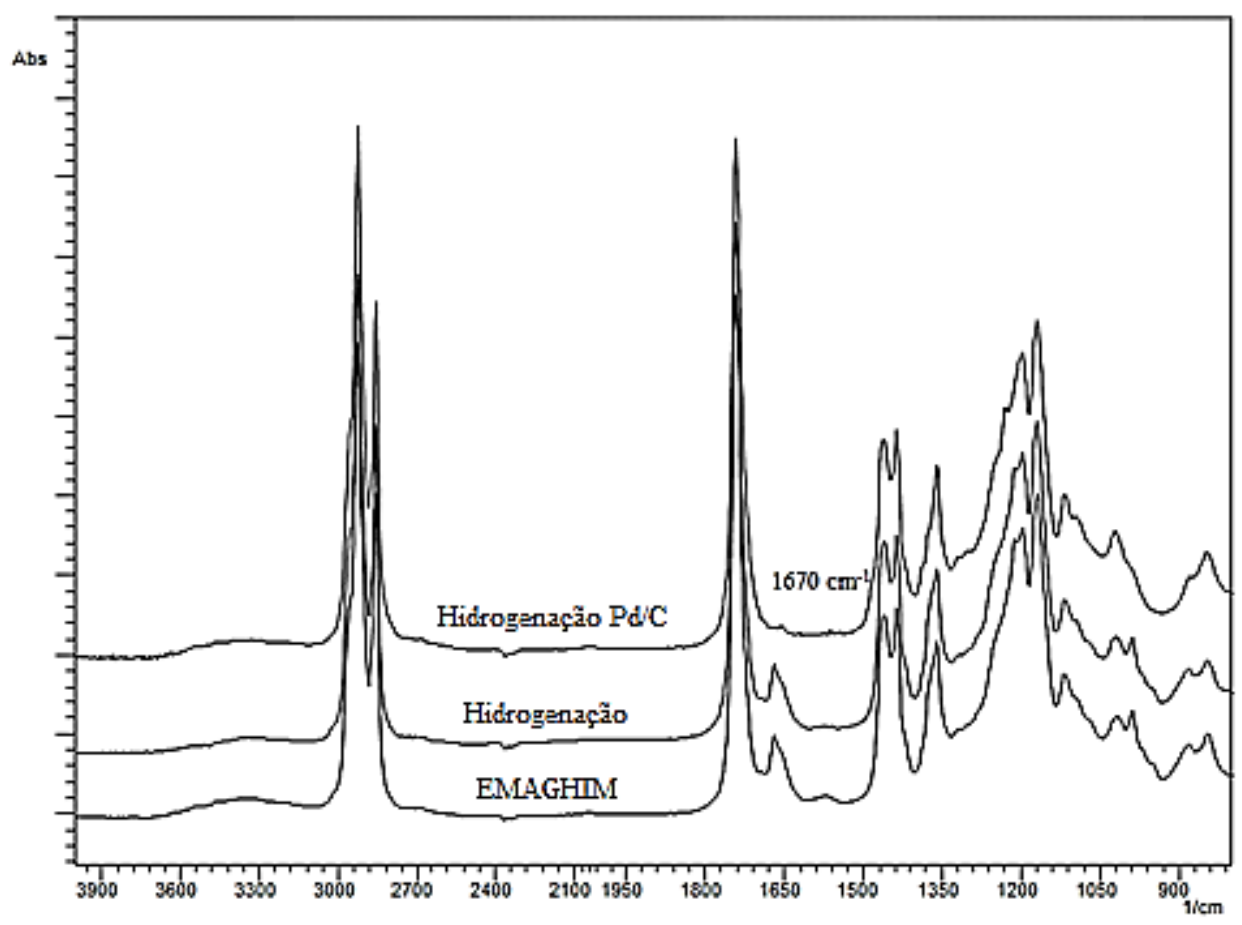

Figura 27. Espectros do EMAGHIM, da sua hidrogenação no mesmo sistema e de sua hidrogenação com $\operatorname{Pd}(C)$.

Entretanto, nem os espectros de infravermelho nem os de $\mathrm{RMN}{ }^{1} \mathrm{H}$ de $60 \mathrm{MHz}$ permitiram identificar o surgimento de sinais relativos à formação de aminas. Com a finalidade de se obter espectros de $\mathrm{RMN}{ }^{1} \mathrm{H}$ melhor resolvidos e, assim, tentar uma identificação mais precisa dos sinais, as análises de $\mathrm{RMN}{ }^{1} \mathrm{H}$ do EMAG, da mistura de partida da reação com Pd/C (LI.0.24.750) e do produto obtido foram realizadas também em um equipamento operando a $600 \mathrm{MHz}$ para hidrogênio.

Os espectros obtidos mostram que, para o EMAG, os hidrogênios-alfa no grupo $-\mathrm{CH}_{2} \mathrm{COOCH}_{3}$ geram um tripleto centrado em 2,31 ppm, com integração de aproximadamente 2H (Figura 18(a)). Por outro lado, no espectro do produto hidroiminometilado (LI.0.24.750), esse sinal passou a apresentar o aspecto de um multipleto e uma integração correspondente a 2,2 H (Figura 28), o que sugere que houve a sobreposição de outro sinal, possivelmente dos hidrogênios do grupo $-\mathrm{C}=\mathrm{NCH}_{2}$ das iminas. De fato, no espectro do produto da reação com $\mathrm{Pd} / \mathrm{C}$, o sinal em 2,31 ppm 
voltou a ter o formato de tripleto (Figura 29), o que estaria de acordo com a conversão total dos grupos imina.

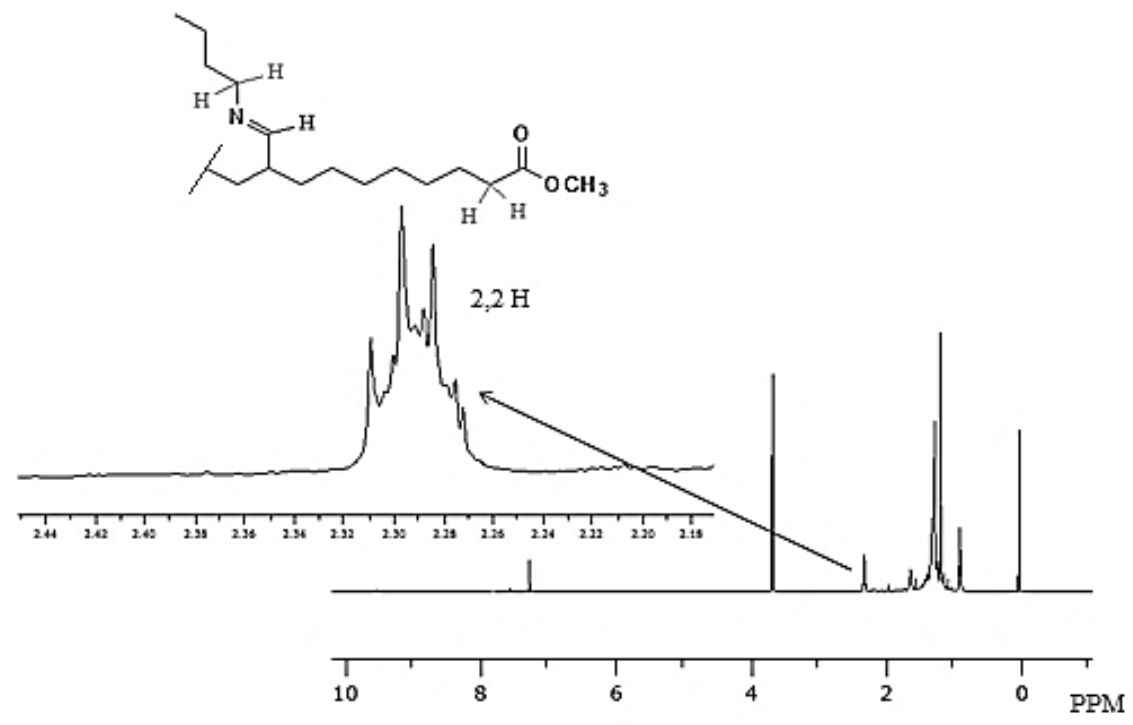

Figura 28. $\mathrm{RMN}{ }^{1} \mathrm{H}$ de $600 \mathrm{MHz}$ da mistura de partida empregada na reação com $\mathrm{Pd} / \mathrm{C}$ (LI.0.24.750).

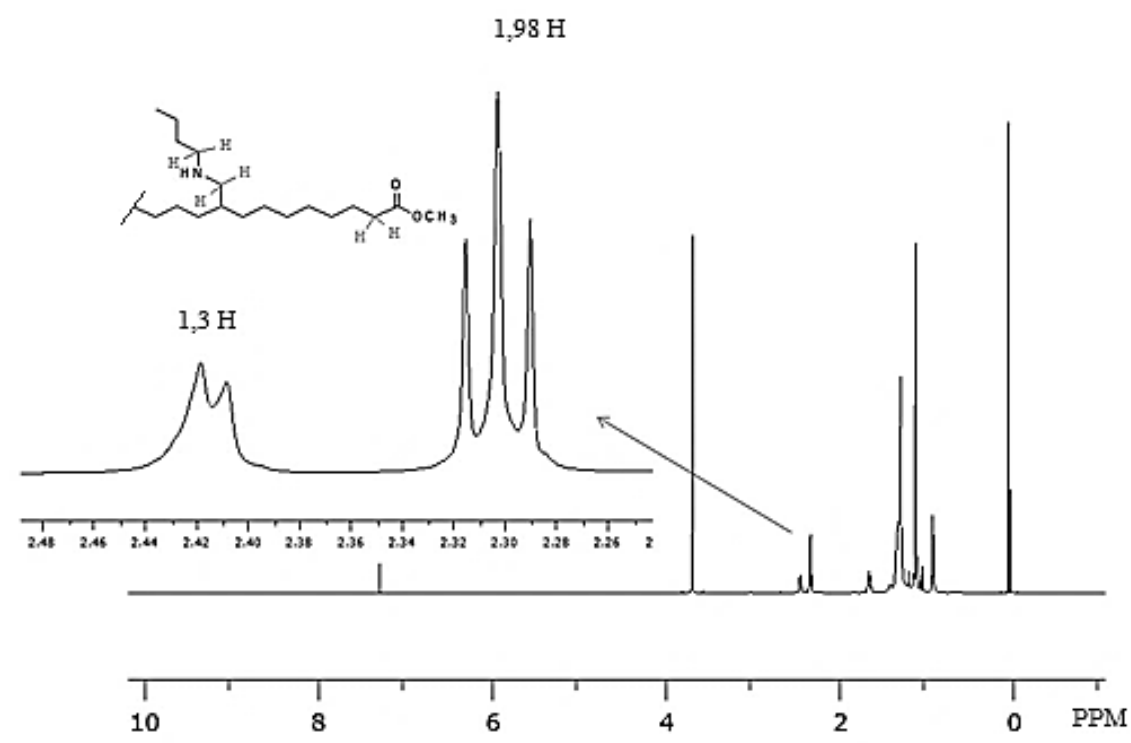

Figura 29. $\mathrm{RMN}{ }^{1} \mathrm{H}$ de $600 \mathrm{MHz}$ do produto de hidrogenação de LI.0.24.750 com $\mathrm{Pd} / \mathrm{C}$.

Entretanto, é válido destacar uma questão que não está de acordo com essa possibilidade: a integração relativa ao hidrogênio $\mathbf{H C}=\mathrm{N}$ no LI.0.24.750 foi de $0,88 \mathrm{H}$ (obtido a partir do espectro de $60 \mathrm{MHz}$ ) e, dessa forma, seria esperada uma integração relativa a 1,76 $\mathrm{H}$ para o sinal dos hidrogênios $\mathrm{C}=\mathrm{NCH}_{2}$; no entanto, se a partir da integração total do multipleto em $2,31 \mathrm{ppm}(2,2 \mathrm{H})$ forem subtraídos os $2 \mathrm{H}$ do grupo 
$\mathrm{CH}_{2} \mathrm{COOCH}_{3}$, então resta uma integração de apenas $0,2 \mathrm{Hs}$ para os hidrogênios do grupo $\mathrm{C}=\mathrm{NCH}_{2}$ das iminas.

Por outro lado, o espectro de $\mathrm{RMN}{ }^{1} \mathrm{H}$ de $600 \mathrm{MHz}$ do produto da reação do LI.0.24.750 com o Pd/C mostrou o surgimento de um sinal, com aspecto de multipleto, em torno de 2,42 ppm. Levando-se em conta sua posição (Behr et al.) ${ }^{79}$ e o fato de que esse sinal não se fazia presente na mistura de partida, é possível atribuí-lo à formação de aminas. A saber, ele resultaria da sobreposição entre um dupleto e um tripleto correspondentes aos hidrogênios-alfa no grupo $\mathrm{CHCH}_{2} \mathrm{NHCH}_{2} \mathrm{CH}_{2}$ (Figura 29). Entretanto, a integração desse sinal foi de apenas $1,3 \mathrm{H}$. Se a integração relativa ao hidrogênio $\mathrm{HC}=\mathrm{N}$ no LI.0.24.750 foi de 0,88 H (60 MHz $\mathrm{MH}^{*}$ e considerando-se uma conversão de $100 \%$ das iminas a aminas, então o sinal relativo aos quatro hidrogêniosalfa no grupo $\mathrm{CHCH}_{2} \mathrm{NHCH}_{2} \mathrm{CH}_{2}$ deveria ser quatro vezes maior, ou seja, de 3,54 $\mathrm{H} \mathrm{em}$ vez do valor de $1,3 \mathrm{H}$ verificado.

A baixa integração verificada para o sinal a 2,42 ppm no espectro do produto da reação com o $\mathrm{Pd} / \mathrm{C}$ poderia sugerir que apenas parte da conversão das iminas tenha resultado em aminas, ocorrendo também a formação de outros produtos, tais como de reações de hidrodesnitrogenação. Entretanto, Krupka e Patera realizaram um minucioso estudo acerca das reações de redução de aldiminas com $\mathrm{Pd} / \mathrm{C}$ e verificaram que a conversão a aminas foi quantitativa, não sendo detectada significativa formação de qualquer outro produto. ${ }^{85}$ Além disso, as análises de $\mathrm{RMN}{ }^{13} \mathrm{C}$ reforçam a ideia de que, a despeito da baixa intensidade do sinal do pico em 2,42 ppm, tenha havido a conversão das iminas a aminas.

Assim, parece que a intensidade dos sinais dos hidrogênios-alfa no grupo $\mathrm{CHCH}_{2} \mathrm{NHCH}_{2} \mathrm{CH}_{2}$ das aminas formadas esteja sendo reduzida devido ao efeito da troca desses hidrogênios com o solvente (efeito similar ao que acontece com o hidrogênio dos grupos $\mathbf{H C}=\mathrm{O}$ e $\mathbf{H C}=\mathrm{N}$, conforme discutido na seção 3.6.2). A hipótese da troca dos hidrogênios com o solvente poderia ser estendida para explicar também a baixa intensidade dos hidrogênios do grupo $\mathrm{C}=\mathrm{NH}_{2}$, em 2,31 ppm, nos espectros do produto LI.0.24.750, conforme citado acima.

Com base na comprovada conversão quantitativa das iminas, na falta de evidências da formação de outros produtos e na comprovada eficiência da conversão de aldiminas a aminas em presença de Pd/C (conforme trabalho de Krupka e Patera), ${ }^{86}$ assumiu-se que as iminas presentes no LI.0.24.750 tenham sido efetivamente 
convertidas a aminas por meio da reação com o Pd/C. Dessa forma, o produto desta reação será chamado, doravante, de EMAGHAM (ésteres de ácido graxo hidroaminometilado). Entretanto, evidências mais concretas dessa conversão serão mostradas em análises de $\mathrm{RMN}{ }^{13} \mathrm{C}$.

\subsubsection{Análises por $\mathrm{RMN}{ }^{13} \mathrm{C}$}

Para melhor caracterizar os produtos de hidroiminometilação e de hidrogenação do EMAGHIM, foram obtidos os seus espectros de RMN ${ }^{13} \mathrm{C}$ APT (Figura 30). Os principais aspectos observados a partir da comparação dos espectros das misturas antes e após a reação são: (i) o desaparecimento do pico negativo em 163 ppm, que é atribuído ao carbono do grupo $\mathrm{HC}=\mathrm{N}$ da mistura EMAGHIM (carbono c); (ii) o aparecimento de um pico positivo em $45 \mathrm{ppm}$, que é atribuído ao carbono do grupo $\mathrm{H}_{2} \mathrm{C}-\mathrm{N}$ do EMAGHAM (carbono c'). É válido destacar que a mudança acentuada no deslocamento dos picos se deve ao fato de que o carbono deixou de apresentar uma ligação dupla. Essas observações corroboram para que os grupos iminas contidos no EMAGHIM tenham sido quantitativamente convertidos em aminas.

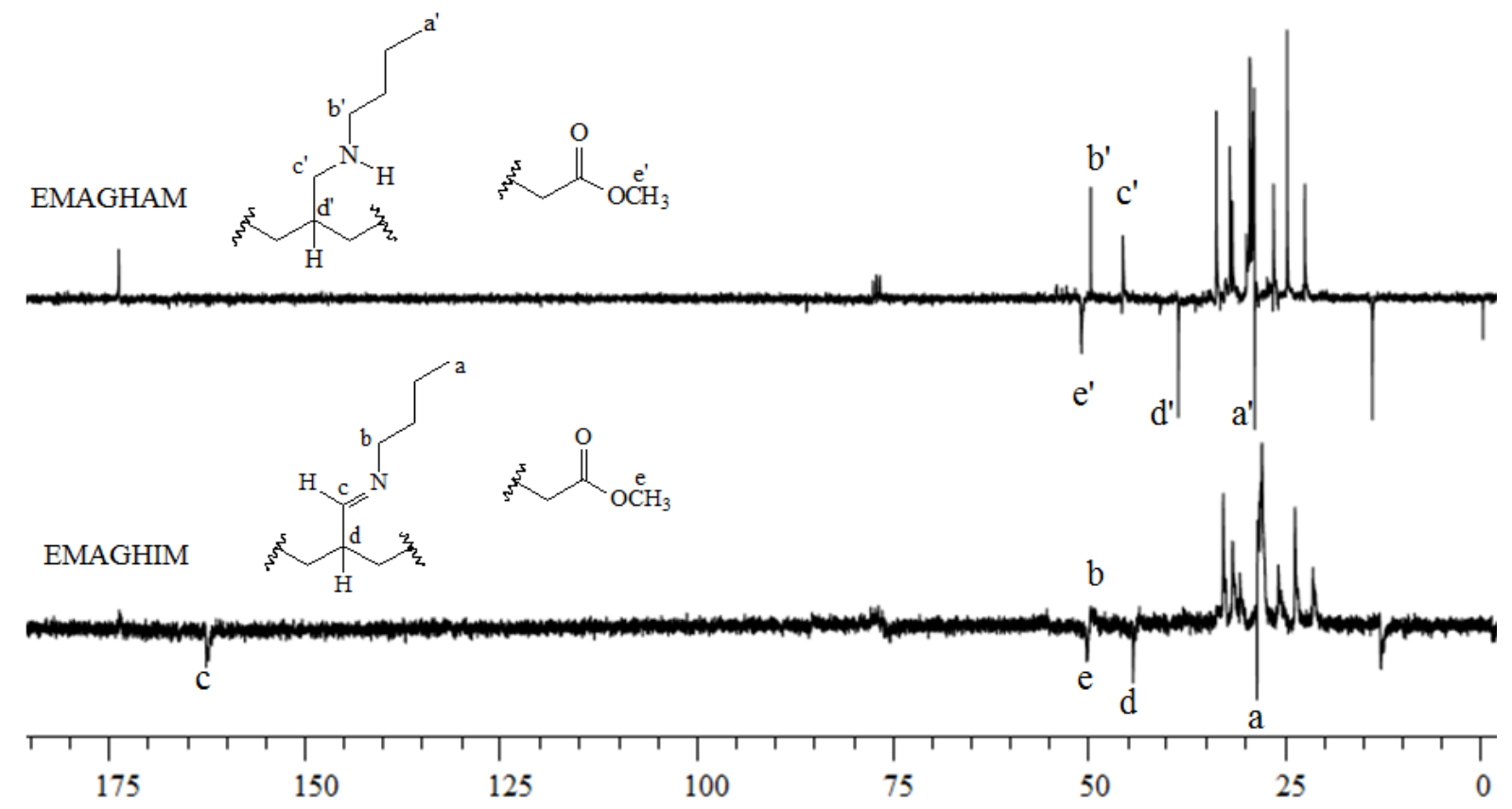

Figura 30. Espectros de RMN ${ }^{13} \mathrm{C}$ (APT) das amostras de EMAGIM e EMAGHAM. 


\subsection{Testes de atividade biológica}

\subsubsection{Teste de difusão em ágar}

Os resultados para os testes de perfuração em ágar usando blendas com diferentes proporções de EMAGHIM/EMAG, para diferentes fungos e bactérias, apresentaram diâmetros de zona de inibição maiores que $10 \mathrm{~mm}$, que é o valor adotado como limite mínimo para caracterizar atividade biocida. Assim, os resultados da Tabela 3 indicam que uma concentração de apenas $0,75 \%$ do produto nitrogenado é suficiente para inibir o crescimento da maioria dos fungos estudados. Por outro lado, as atividades biocidas para bactérias foram menos pronunciadas, sendo $5 \%$ a concentração mínima necessária para inibir o crescimento de E. coli e S. aureus, e uma concentração de $10 \%$ para inibir o crescimento de B. subtillis. Os diâmetros da zona de inibição foram, de forma geral, consideravelmente menores para as bactérias do que para os fungos.

Tabela 3. Resultados do teste de perfuração em ágar, para fungos, das blendas EMAGHIM/EMAG.

\begin{tabular}{|c|c|c|c|c|c|c|c|c|c|}
\hline \multirow{3}{*}{ Fungos } & \multicolumn{9}{|c|}{ Diâmetro da zona de inibição (mm) } \\
\hline & \multicolumn{9}{|c|}{ Concentração das blendas EMAGHIM/EMAG (v/v) } \\
\hline & $0,25 \%$ & $0,5 \%$ & $0,75 \%$ & $1 \%$ & $5 \%$ & $10 \%$ & $25 \%$ & $50 \%$ & $100 \%$ \\
\hline C. krusei & - & - & 11,0 & 12,0 & 12,0 & 13,0 & 13,0 & 16,3 & 14,6 \\
\hline C. parapsilosis & - & - & - & 12,5 & 16,5 & 16,3 & 26,0 & 26,0 & 35,0 \\
\hline C. albicans & - & - & 15,5 & 15,0 & 15,2 & 20.0 & 18,0 & 17,5 & 26,5 \\
\hline A. niger & - & - & 12,5 & 13,0 & 15,2 & 15.5 & 16,0 & 20,0 & 24,3 \\
\hline A. fumigatus & - & - & 13,4 & 13,5 & 14,0 & 14,5 & 15,0 & 18,3 & 23,5 \\
\hline S. cerevisae & - & - & - & - & 14,2 & 15,5 & 16,2 & 16,8 & 17,3 \\
\hline
\end{tabular}


Tabela 4. Resultados do teste de perfuração em ágar, para bactérias, das blendas EMAGHIM/EMAG.

\begin{tabular}{cccccccccc}
\hline & \multicolumn{7}{c}{ Diâmetro da zona de inibição (mm) } \\
\cline { 2 - 9 } Bactéria & \multicolumn{7}{c}{ Concentração das blendas EMAGHIM/EMAG (v/v) } \\
\cline { 2 - 9 } & $0,25 \%$ & $0,5 \%$ & $0,75 \%$ & $1 \%$ & $5 \%$ & $10 \%$ & $25 \%$ & $50 \%$ & $100 \%$ \\
\hline E. coli & - & - & - & - & 12,0 & 14,5 & 16,5 & 16,0 & 17,0 \\
\hline B. subtillis & - & - & - & - & - & 13,0 & 13,5 & 14,4 & 15,8 \\
\hline S. aureus & - & - & - & - & 11,0 & 11,3 & 12,5 & 14.6 & 15,3 \\
\hline
\end{tabular}

\subsubsection{Teste da suscetibilidade utilizando o EMAGHIM}

O teste de suscetibilidade foi realizada apenas para as blendas que apresentaram atividade biocida satisfatória de acordo com o teste de perfuração em ágar. As concentrações inibitórias mínimas (CIM) apresentaram grande variação de acordo com o fungo ou bactéria estudado. Os resultados foram melhores para fungos do que para bactérias, sendo que o fungo A. fumigatus apresentou a menor CIM.

Tabela 5. CIM das blendas de EMAGIM/EMAG no teste de suscetibilidade fúngica.

\begin{tabular}{lccccccc}
\hline & \multicolumn{7}{c}{ Concentração Inibitória Mínima $(\mu \mathrm{g} / \mathrm{ml})$} \\
\cline { 2 - 7 } Fungo & \multicolumn{7}{c}{ Concentrção das blendas de EMAGIM/EMAG $(\mathrm{v} / \mathrm{v})$} \\
\cline { 2 - 7 } & $0,75 \%$ & $1 \%$ & $5 \%$ & $10 \%$ & $25 \%$ & $50 \%$ & $100 \%$ \\
\hline C. krusei & 512 & 512 & 512 & 256 & 256 & 128 & 128 \\
\hline C. parapsilosis & - & 512 & 512 & 512 & 512 & 512 & 512 \\
\hline C. albicans & 512 & 256 & 256 & 256 & 256 & 256 & 256 \\
\hline A. niger & 512 & 256 & 256 & 256 & 256 & 128 & 64 \\
\hline A. fumigatus & & & & & & & \\
\hline S. cerevisae & 256 & 256 & 128 & 128 & 128 & 128 & 64 \\
\hline
\end{tabular}


Tabela 6. CIM das blendas de EMAGIM/EMAG no teste de suscetibilidade bacteriana.

\begin{tabular}{|c|c|c|c|c|c|}
\hline \multirow{3}{*}{ Bactéria } & \multicolumn{5}{|c|}{ Concentração Inibitória Mínima ( $\mu \mathrm{g} / \mathrm{ml})$} \\
\hline & \multicolumn{5}{|c|}{ Concentrção das blendas de EMAGIM/EMAG (v/v) } \\
\hline & $5 \%$ & $10 \%$ & $25 \%$ & $50 \%$ & $100 \%$ \\
\hline E. coli & 512 & 512 & 512 & 512 & 256 \\
\hline B. subtillis & - & 512 & 512 & 256 & 256 \\
\hline S.aureus & 512 & 512 & 512 & 256 & 256 \\
\hline
\end{tabular}

\subsubsection{Resultados para o teste de inibição de crescimento de microrganismos com pesagem da biomassa fúngica}

A Figura 31 apresenta um gráfico que compara o peso seco da massa fúngica quando o EMAGHIM é adicionado ao biodiesel (proporção $5 \%$ em volume) com o peso seco para a massa fúngica do EMAG sem aditivos. É possível concluir que a blenda contendo $5 \%$ de EMAGHIM apresentou uma redução de aproximadamente 25 $\%$ do fungo A. fumigattus com relação ao EMAG puro, indicando que o EMAGHIM popode ser usado como aditivo biocida.

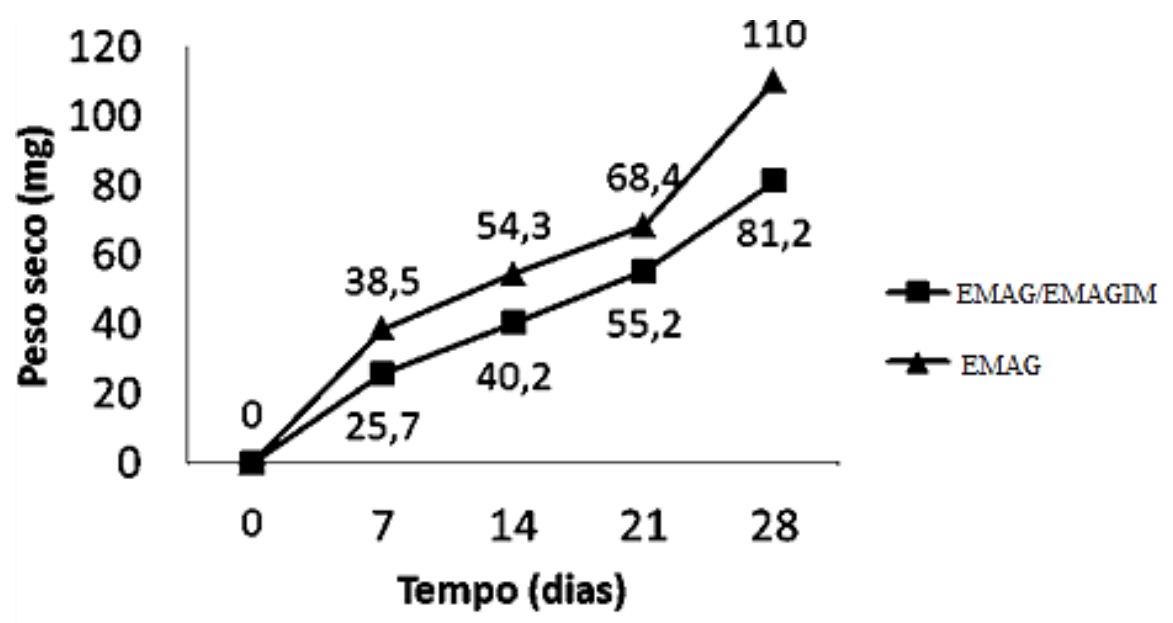

Figura 31. Valores de peso seco da biomassa fúngica para as amostras de EMAG puro e EMAG/EMAGHIM 5 \% (v/v). 
CONSIDERAÇÕES FINAIS 


\section{Considerações finais}

Um Sistema catalítico bifásico utilizando o líquido iônico hexafluorofosfato de 1-butil-3-metilimidazolio foi empregado para a reação de hidroformilação de EMAG na presença de $n$-butilamina usando o precursor catalítico $\mathrm{HRhCO}\left(\mathrm{PPh}_{3}\right)_{3}$. O sistema favoreceu a formação de iminas, visto que a hidrogenação das iminas para formação de aminas foi impedida pela presença de ligantes doadores de elétrons no sistema $\left(\mathrm{PPh}_{3}\right.$ presente no precursor catalítico) que formam espécies catalíticas que não são ativas para hidrogenação.

$\mathrm{Na}$ presença de um excesso de ligante $\mathrm{PPh}_{3}$, o emprego do líquido iônico aumentou a seletividade para formação de imina quando comparado com a reação realizada em condições similares, mas em meio homogêneo. O rendimento para imina chegou a 75\% após 24 h de reação. Por outro lado, na ausência de um excesso de $\mathrm{PPh}_{3}$, houve uma diminuição na conversão das ligações duplas. Uma hipótese levantada é que este comportamento pode ser atribuído à formação de carbenos $N$-heterocíclicos, que podem coordenar com o $\mathrm{Rh}$ para formar espécies catalíticas ativas para reações paralelas e/ou consecutivas. Estas espécies, por possuírem ligantes com característica doadora de elétrons, também são ativas para a hidroformilação, mas com menor intensidade. Quando um excesso de $\mathrm{PPh}_{3}$ é empregado, ele suprime a coordenação dos carbenos, mantendo o Rh em uma forma mais ativa para a reação de hidroformilação.

Apesar de alguns ajustes ainda serem necessários para melhorar a capacidade de reciclo da fase iônica contendo o catalisador, o sistema aqui empregado foi muito eficiente para produzir EMAG funcionalizado com o grupo imina. Este produto apresentou uma atividade antimicrobiana satisfatória contra fungos e bactérias normalmente presentes em tanques de armazenamento de combustíveis. Estes resultados mostram que o biodiesel modificado tem um grande potencial para ser usado como um aditivo biocida para combustíveis. 
REFERÊNCIAS BIBLIOGRÁFICAS 
1. ANP, 2015. Boletim Mensal do Biodiesel de Agosto de 2015. Agência Nacional do Petróleo, Gás Natural e Biocombustíveis. Disponível em http://www.ubrabio.com.br/1891/Noticias/BoletimMensalDoBiodieselAnpEdicaoDe Agosto_252904/ acessado em 18 de setembro, 2015.

2. Meneghetti, S. M. P.; Meneghetti, M. R.; Brito, Y. C.Rev. Virtual Quim. 2013, 5 (1), 63.

3. Salvi, B.L.; Panwarb, N.L.; Renew. Sustain. Energ. Rev.2012, 16, 3680.

4. Dupont, J.; Suarez, P. A. Z.; Meneghetti, M. R.; Energy Environ. Sci. 2009, 12, 1258.

5. Ramalho, H. F.; Suarez, P.A.Z.; Rev.Vir. Quim. 2013, 5, 2.

6. Meneghetti, S. M. P.; Meneghetti, M. R.; Serra, T. M.; Barbosa, D. C.; Wolf, C. R.; Energy Fuels 2007, 21, 3746.

7. Resolução ANP 42, 2011.

8. Yemashova, A. N.; Murygina, V. P.; Zhukov, D. V.; Zakharyantz, A. A.; Gladchenko, M. A.; Appanna, V.; Kalyuzhnyi, S. V.; Rev. Environ. Sci. Bio/Technol. 2007, 6, 315.

9. Yemashova, A. N.; Murygina V. P.; Zhukov D. V.; Zakharyantz A. A.; Gladchenko M. A.; Appanna V.; Kalyuzhnyi S. V.; Science and Biotech. 2007, 6, 315.

10.Carvalho, M. S.; Lacerda, R. A.; Leao, J. P. B.; Scholten, J. D.; Neto, B. A. D.; Suarez, P. A. Z.; Catal. Sci. Technol. 2011, 1, 480.

11.Silva, W. S. D.; Lapis, A. A. M.; Suarez, P. A. Z.; Neto, B. A. D.; J. Mol. Catal. B: Enzym.2011, 68, 98.

12.de Oliveira, V. M.; de Jesus, R. S.; Gomes, A. F.; Gozzo, F. C.; Umpierre, A. P.; Suarez, P. A. Z.; Rubim, J. C.; Neto, B. A. D.; ChemCatChem. 2011, 3, 1911.

13.Behr, A.; Vorholt, A. J.;Top. Organomet. Chem. 2012, 39, 103.

14. Ramalho, H. F.; di Ferreira, K. M. C.; Machado, P. M. A.; Oliveira, R. S.; Silva, L. P.; Prauchner, M. J.; Suarez, P. A. Z.; Ind. Crops Prod. 2014, 52, 211.

15. Ramalho, H. F.; Síntese de novos derivados de biodiesel de soja via reação de carbonilação em sistema bifásico. Março/2010 - Dissertação de Mestrado - Instituto de Química, Universidade de Brasília. Brasília - DF. 
16.Eilbracht, P.; Bärfacker, L.; Buss, C.; Hollmann, C.; Kitsos- Rzychon, B. E.;Kranemann, C. L.; Rische, T.; Roggenbuck, R.; Schmidt, A.; Chem. Rev. 1999, 99, 3329.

17.Graebin, C. S.; Madeira, M. F.; Yokoyama-Yasunaka, J. K. U.;Miguel, D. C.; Uliana, S. R. B.; Benitez, D.; Cerecetto, H.; González, M.; Rosa, R. G.; Eifler-Lima, V. L.; Eur. J. Med. Chem. 2010, 45, 1524.

18.Farrell, E. K.; Merkler, D. J.; Drug Discovery Today 2008, 13, 558.

19. Suarez, P. A. Z, Meneghetti, S. A. P.; Quím. Nova 2007, 30, 2068.

20.Pousa, G. P. A. G. ; Santos, A. L. F. ; Suarez, P. A. Z.; Energy Policy 2007, 35, 5393.

21. Coultat, T.P. Alimentos: a química e seus componentes; Editora Artmed; Porto Alegre, 2004, p. 63.

22.Moser, B. R.; Haas, M. J.;Winkler, J. K.; Jackson,M. A., Erhan, S. Z.; List,G. R.;Eur. J. Lipid Sci. Technol.2007, 109, 17.

23.Pasqualino J.C.; Montané D.; Salvadó J.; Biomass and Bioenergy 2006, 30, 894.

24.Mudge, S. M.; Pereira, G. Spill Sci.\& Tech. Bulletin 1999, 5, 353.

25.Passman, F. and Dobranick, J, K., 2005. Relative biodegradability of B-100 biodiesel and conventional low sulfur diesel fuels. In: Proceedings of 9th International Conference on Stability, Handling and Use of Liquid Fuels, 2005. Sidges. Sidges: IASH. p. 18-22.

26. Gaylarde, C.C.; Bento, F.M.; Kelley, J.; Revista de Microbiologia 1999, 30, 1.

27. Bücker, F., Santestevan, N.A.;, Roesch, L.F., Jacques, R. J. S., Peralba, M. C. R., Camargo, F.A.O; Bento, F.M.; International Biodeterioration \& Biodegradation 2011, 65, 172.

28. Schleicher, T.; Werkmeister, R., Russ, W.; Meyerpittroff, R.; Biores. Technol. 2009 $100,724$.

29.Zimmer, A.R.; Cazarolli, J.C.; Teixeira, R.M.; Viscardi, S.L.C.; Cavalcanti, E.S.H.; Gerbase, A.E.; Ferrão, M.F.; Piantnicki, C.M.S.; Bento, F.M.; Fuel 2013, 112, 153.

30.Mariano, A. P.; Tomasella, R. C.; de Oliveira, L. M.; Contiero, J.; de Angelis, D. F.; African Journal of Biotechnology 2008, 7, 1323

31.Owsianiak, M.; Chrzanowski, L; Szulc, A.; Staniewski, J.; Olszanowski, A.; Olejnik-Schmidt, A. K.; Heipieper; H. J.; Bioresource Technology 2009, 3, 1497 
32.Bento, F. M. and Gaylarde, C. C.; Int.Biodeter.\& Biodegrad.2001, 2, 107.

33.Rios, J. L.; Recio, M. C.; Villar, A.; J. of Ethnopharmacol. 1988, 23, 127.

34. Barnett J. A; Payne, R. W.; Yarrow, W. Yests Charactherization and Identificaition, 2000, 1139

35.Passman, F. J.; Int. Biodeter. Biodegr. 2013, 81, 88.

36.Dupont, J., Suarez, P.A.Z.; Phys. Chem. Chem. Phys. 2006, 8, 2441.

37.Dupont, J., J. Braz. Chem. Soc. 2004, 15, 341.

38. Neto, B. A. D.; Spencer, J.; J. Braz. Chem. Soc. 2012, 23, 987.

39.Haumann, M.; Riisager, A.; Chem. Rev. 2008, 108, 1474

40.Barros, H. J. V; Hanson, B. E.; Gusevskaya, E. V.; dos Santos, E. N.; Appl. Catal. A: Gen. 2004, 278, 57.

41.Petkovic, M.; Seddon, K. R.; Rebelo, L. P.; Pereira, C. S.; Chem. Soc. Rev. 2011, $40,1383$.

42.Dupont, J.; Spencer, J.; Angew. Chem. Int. Ed. 2004, 43, 5296.

43.Thomas, M.; Brehm, M., Hollóczki, O.; Kirchner, B.; Chem. Eur. J. 2014, 20, 1622.

44.Jacobsen, H.; Correa, A.; Poater, A.; Costabile, C.; Cavallo, L.; Coord. Chem. Rev. 2009, 253, 687.

45. Chen, C.; Ren, L.; Decken, A.; Crudden, C. M.; Organometallics 2000, 19, 3459.

46.Franke, R.; Selent, D.; Börner, A.; Chem. Rev. 2012, 112, 5675.

47.Trzeciak, A. M.; Ziólkowski, J. J.; Coord. Chem. Rev. 1999, 190, 883.

48.Beller, M.; Cornils, B.; Frohning, C. D.; Kohlpainter, C. W.; J. Mol. Catal. A: Chem. 1995, 104, 17.

49.Eilbracht, P.; Bärfacker, L.; Buss, C.; Hollmann, C.; Kitsos-Rzychon, B.E.; Kranemann, C. L.; Rische, T.; Roggenbuck, R.; Schmidt, A.; Chem. Rev. 1999, 99, 3329.

50.Salinas-Olvera, J. P.; Gómez, R. M.; Cortés-Gúzman, F.; J. Phys. Chem. A. 2008, 112, 2906.

51.Kainulainen, T.A.; Niemelä, M.K.; Krause, A.O.I.; J. Mol. Catal. A: Chem. 1997, $122(1), 39$.

52.Zhang, Y.; Zhang, H.; Lin, G.; Chen, P.; Yuan, Y.; Tsai, K.R.; Appl. Catal. A: Gen. 1999, 187, 213.

53.Frankel, E.N.; J. Am. Oil Chem. Soc. 1976, 53 (4), 138. 
54.Kim, T.; Celik, F.E.; Hanna, D.G.; Shylesh, S.; Werner, S.; Bell, A.T.; Top. Catal. 2011, 54, 299.

55.Davis, M.E., Butler, P.M., Rossin, J.A., 1985. Hydroformylation of 1-hexene by solubleand zeolite-supported rhodium species. J. Mol. Catal. 31, 385-395.

56.Fujita, S., Akihara, S., Fujisawa, S., Arai, M.; J.Mol. Catal. A: Chem. 2007, 268, 244.

57.Bruss, A. J.; Gelesky, M. A.; Machado, G.; Dupont, J.; J. Mol. Catal. A: Chem. 2006, 252, 212.

58.Sun, L. J.; Yao, C.; Zheng, H. F.; Lin, J.; Chin. Chem. Lett. 2012, 23, 919.

59. Sun, Z.; Wang, Y.; Niu, M.; Yi, H.; Jiang, J.; Jin, Z.; Catal. Commun. 2012, 27, 78.

60.Zeng, Y.; Wang, Y.; Xu, Y.; Song, Y.; Zhao, J.; Jiang, J.; Jin, Z.; Chin. J. Catal. 2012, 33, 402 .

61. Adams, D. J.; Dyson, P. J.; Tavener, S. J.; Chemistry in Alternative Reaction Media, first ed. John Wiley \& Sons, England, 2005.

62.Papadogianakis, G.; Sheldon, R. A.; 1997. Catalytic conversions in water. An environmentally benign concept for heterogenization of homogeneous catalysis. In: Spivey, J. J. (Ed.), Catalysis 13. Royal Society of Chemistry, pp. 114.

63. Arhancet, J. P.; Davis, M. E., Hanson, B. E.; J. Catal. 1991, 129, 94.

64. Disser, C.; Muennich, C.; Luft, G.; Appl. Catal. A: Gen. 2005, 296, 201.

65.Dupont, J.; De Souza, R. F.; Suarez, P. A. Z.; Chem. Rev. 2002, 102, 3667.

66. Haumann, M.; Riisager, A.; Chem. Rev. 2008,108, 1474.

67.Botteghi, C.; Ganzerla, R.; Lenarda, M.; Moretti, G.; J. Mol. Catal. 1987, 40, 129.

68. Kandanarachchi, P.; Guo, A.; Petrovic, Z.; J. Mol. Catal.A: Chem. 2002, 184, 65.

69. Mendes, A. N. F.; Gregorio, J. R.; da Rosa, R.G.; J. Braz. Chem. Soc. 2005, 16 (6A), 1124.

70.Frankel, E. N.; J. Am. Oil Chem. Soc.1971, 48, 248.

71.Fell, B.; Leckel, D.; Schobben, C.; Fat Sci. Technol. 1995, 97, 219.

72. Boulanger, J.; Ponchel, A.; Bricout, H.; Hapiot, F.; Monflier, E.; Eur. J. Lipid Sci. Technol. 2012, 114, 1439.

73.Panda, A. G.; Bhor, M. D.; Jagtap, S. R.; Bhanage, B. M.; Appl. Catal. A: Gen. 2008, 347, 142 . 
74.Eilbracht, P.; Bärfacker, L.; Buss, C.; Hollmann, C.; Kitsos-Rzychon, B. E.; Kranemann, C. L.; Rische, T.; Roggenbuck, R.; Schmidt, A.; Chem. Rev. 1999, 99, 3329.

75. Goedheijt, M. S.; Kamer, P.; van Leeuwen, P.; J. Mol. Catal. A 1998, 134, 243.

76.Mendes, A. N. F.; Gregorio, J. R.; da Rosa, R.G.; J. Braz. Chem. Soc. 2005, 16 (6A), 1124.

77.Klofutar, B.; Golob, J.; Acta Chim. Slov. 2007, 54, 744.

78.Behr, A.; Fiene, M.; Buß, C; Eilbracht, C.; Eur. J. Lipid Sci. Technol. 2000, 102, 467.

79. Carvalho, M. S.; Mendonça, M. A.; Pinho, D. M. M.; Resck, I. S.; Suarez, P. A. Z.; J. Braz. Chem. Soc. 2012, 23, 763.

80.Cassol, C.C.; Ebeling, G.; Ferrera, B.; Dupont, J.; Adv. Synth. Catal. 2006, 348, 243.

81.Briggs, J.; Klosin, J.; Whiteker, G.; Org. Let. 2005, 7(22), 4795.

82.dos Santos, E. N.; Organomet. Chem. 2003, 671, 150.

83. Clarke, M. L.; Diaz-Venezuela, M. B.; Slawin, A. M. Z.; Organometallics 2007, 26, 16.

84.Ohno, K.; Tsuji, J.; J. Am. Chem. Soc. 1968, 90, 99.

85.Krupka, J.; Patera, J.; App. Cat. A: Gen. 2007, 330, 96.

86. Bento, F. M.; Gaylarde, C. C.; Braz. J. Microbiol. 1996, 27, 192. 